Prepared in cooperation with the

Kansas Water Office and the

Kansas Department of Health and Environment

\title{
Estimation of Sediment Sources Using Selected Chemical Tracers in the Perry Lake and Lake Wabaunsee Basins, Northeast Kansas
}

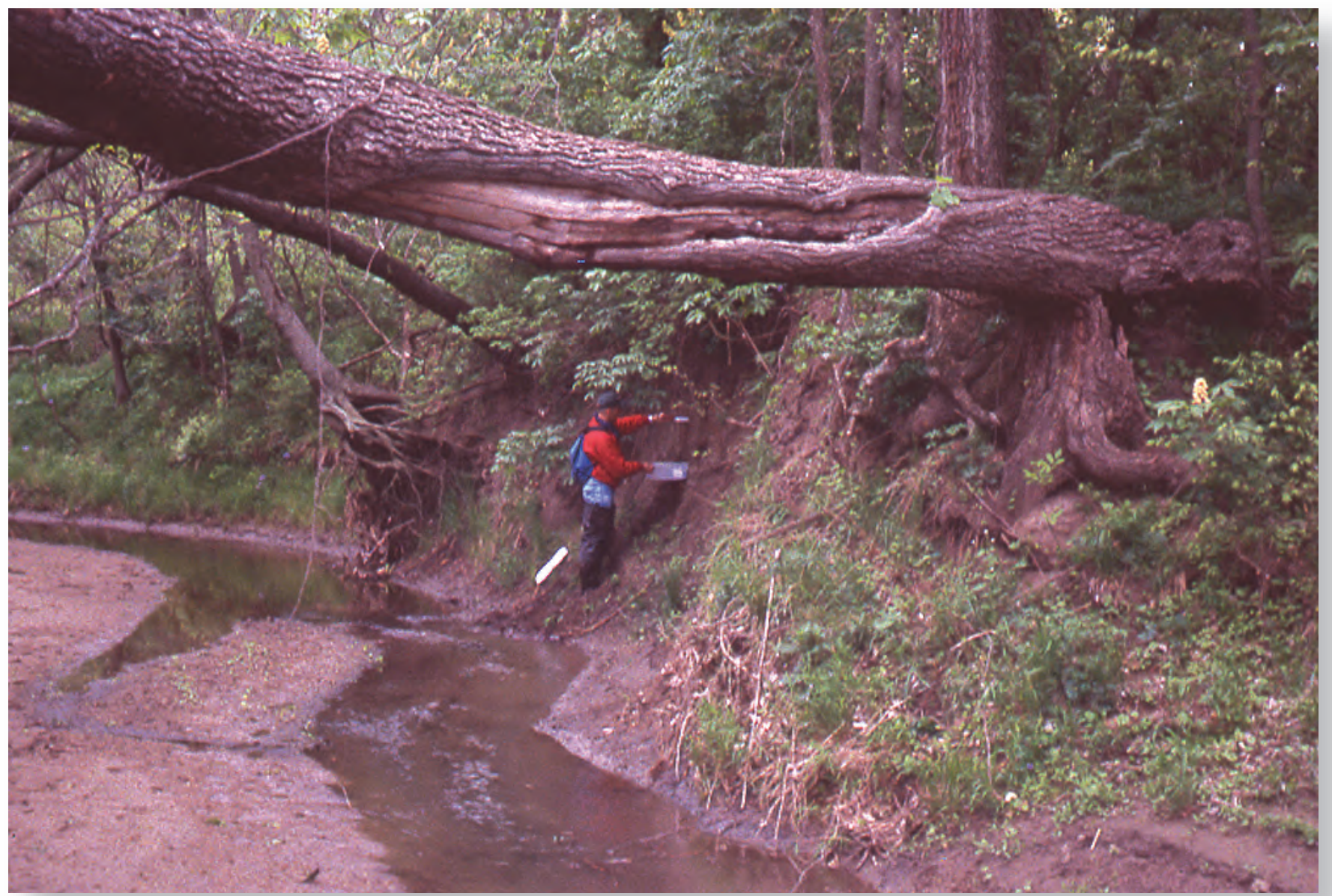

Scientific Investigations Report 2007-5020 



\section{Estimation of Sediment Sources Using Selected Chemical Tracers in the Perry Lake and Lake Wabaunsee Basins, Northeast Kansas}

By Kyle E. Juracek and Andrew C. Ziegler

Prepared in cooperation with the Kansas Water Office and the

Kansas Department of Health and Environment

Scientific Investigations Report 2007-5020 


\section{U.S. Department of the Interior DIRK KEMPTHORNE, Secretary}

\section{U.S. Geological Survey \\ Mark D. Myers, Director}

\section{U.S. Geological Survey, Reston, Virginia: 2007}

For product and ordering information:

World Wide Web: http://www.usgs.gov/pubprod

Telephone: 1-888-ASK-USGS

For more information on the USGS — the Federal source for science about the Earth, its natural and living resources, natural hazards, and the environment:

World Wide Web: http://www.usgs.gov

Telephone: 1-888-ASK-USGS

Any use of trade, product, or firm names is for descriptive purposes only and does not imply endorsement by the U.S. Government.

Although this report is in the public domain, permission must be secured from the individual copyright owners to reproduce any copyrighted materials contained within this report.

Suggested citation:

Juracek, K.E., and Ziegler, A.C., 2007, Estimation of sediment sources using selected chemical tracers in the Perry Lake and Lake Wabaunsee Basins, northeast Kansas: U.S. Geological Survey Scientific Investigations Report 2007$5020,53 p$.

Front cover: Photograph showing channel-bank sampling, spring 2005.

Back cover: Photographs showing (clockwise from upper left) cropland-soil, grassland-soil, channel-bank, and reservoir bottom-sediment sampling, spring 2005. 


\section{Contents}

Abstract Introduction
Description of Reservoir Basins
$\quad$ Perry Lake
Lake Wabaunsee

\section{Figures}

1-8. Maps showing:

1. Physiography of Kansas and location of Perry Lake and Lake Wabaunsee .............3

2. Location of Delaware River Basin, Perry Lake, land use in the basin, the five subbasins selected for study, and location of channel-bank, cropland-soil, grassland-soil, and reservoir bottom-sediment sampling sites.

3. Location of Lake Wabaunsee Basin, Lake Wabaunsee, land use in the basin, and location of channel-bank, grassland-soil, and reservoir bottom-sediment sampling sites.

4. Location of Atchison County Lake subbasin, Atchison County Lake, land use in the subbasin, and location of channel-bank, cropland-soil, grassland-soil, and reservoir bottom-sediment sampling sites

5. Location of Banner Creek Reservoir subbasin, Banner Creek Reservoir, land use in the subbasin, and location of channel-bank, cropland-soil, grassland-soil, and reservoir bottom-sediment sampling sites

6. Location of Gregg Creek subbasin, land use in the subbasin, and location of channel-bank, cropland-soil, and grassland-soil sampling sites.

7. Location of Mission Lake subbasin, Mission Lake, land use in the subbasin, and location of channel-bank, cropland-soil, grassland-soil, and reservoir bottomsediment sampling sites.

8. Location of Walnut Creek subbasin, land use in the subbasin, and location of channel-bank, cropland-soil, and grassland-soil sampling sites. 
9. Flowchart showing criteria used to select constituents that discriminate between channel-bank and surface-soil sediment sources

10-14. Graphs showing comparison of channel-bank, surface-soil, and reservoir bottomsediment composition using clay-normalized total nitrogen, total phosphorus, and total organic carbon concentrations, clay-normalized cesium-137 activity, and ratios of total organic carbon to total nitrogen, total organic carbon to total phosphorus, and total nitrogen to total phosphorus for:

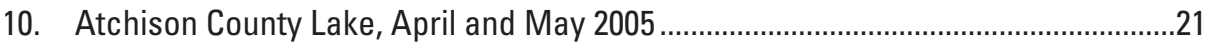

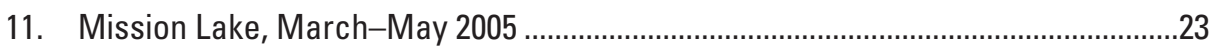

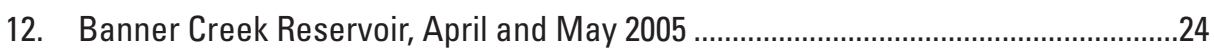

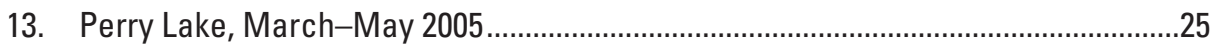

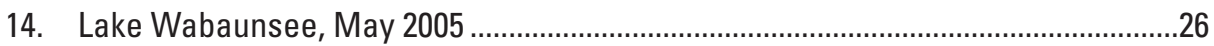

\section{Tables}

1. Land use in the Delaware River Basin, five selected subbasins within the Delaware River Basin, and the Lake Wabaunsee Basin, northeast Kansas, 1988-90...

2. Sediment-source type and number of samples collected and analyzed for the Perry Lake and Lake Wabaunsee Basins, northeast Kansas, March-May 2005

3. Chemical analyses performed on channel-bank, cropland-soil, grassland-soil, and reservoir bottom-sediment samples from the Perry Lake and Lake Wabaunsee Basins, northeast Kansas.

4. Relative percentage differences for constituent concentrations and cesium-137 activity in split-replicate samples of surface soil and bottom sediment from the Perry Lake and Lake Wabaunsee Basins, northeast Kansas, April and May 2005

5. Range in original total nitrogen, total phosphorus, and total organic carbon concentrations and cesium-137 activity for channel-bank, cropland-soil, and grassland-soil sampling sites in the Mission Lake subbasin, northeast Kansas, March-May 2005......19

6. Summary of sediment sources for reservoirs as indicated by clay-normalized constituents and constituent ratios.

A1-A5. Percentage of clay and original and clay-normalized constituent concentrations and cesium-137 activity for channel-bank, cropland-soil, grassland-soil, and reservoir bottom-sediment samples collected in the:

A1. Atchison County Lake subbasin, northeast Kansas, April and May 2005 ...............32

A2. Banner Creek Reservoir subbasin, northeast Kansas, April and May 2005 .............34

A3. Gregg Creek subbasin, northeast Kansas, March and April 2005...........................36

A4. Mission Lake subbasin, northeast Kansas, March-May 2005..................................37

A5. Walnut Creek subbasin, northeast Kansas, April and May 2005.............................39

A6. Percentage of clay and original and clay-normalized constituent concentrations and cesium-137 activity for bottom-sediment samples collected from Perry Lake, northeast Kansas, May 2005.

A7. Percentage of clay and original and clay-normalized constituent concentrations and cesium-137 activity for channel-bank, grassland-soil, and reservoir bottom-sediment samples collected in the Lake Wabaunsee Basin, northeast Kansas, May 2005............41 
A8. Original total nitrogen, total phosphorus, and total organic carbon concentrations and cesium-137 activity for channel-bank, cropland-soil, grassland-soil, surface-soil, and reservoir bottom-sediment samples collected in the Perry Lake and Lake Wabaunsee Basins, northeast Kansas, March-May 2005

A9. Percentage of clay and original constituent concentrations and cesium-137 activity for channel-bank samples collected at individual sites in the Mission Lake subbasin, northeast Kansas, March and April 2005.

A10. Percentage of clay and original constituent concentrations and cesium-137 activity for cropland-soil samples collected at individual sites in the Mission Lake subbasin, northeast Kansas, March and April 2005.....

A11. Percentage of clay and original constituent concentrations and cesium-137 activity for grassland-soil samples collected at individual sites in the Mission Lake subbasin, northeast Kansas, May 2005.

A12. Ratios of total organic carbon to total nitrogen, total organic carbon to total phosphorus, and total nitrogen to total phosphorus for channel-bank, cropland-soil, grasslandsoil, surface-soil, and reservoir bottom-sediment samples collected in the Perry Lake and Lake Wabaunsee Basins, northeast Kansas, March-May 2005

A13. Clay-normalized total nitrogen, total phosphorus, and total organic carbon concentrations and clay-normalized cesium-137 activity for channel-bank, cropland-soil, grassland-soil, surface-soil, and reservoir bottom-sediment samples collected in the Perry Lake and Lake Wabaunsee Basins, northeast Kansas, March-May 2005.

A14. Percentage of clay and original and clay-normalized constituent concentrations and cesium-137 activity for channel-bank samples collected from the Delaware River, northeast Kansas, April and May 2005.

A15. Latitude and longitude coordinates for sampling sites in the Perry Lake and Lake Wabaunsee Basins, northeast Kansas 


\section{Conversion Factors, Abbreviations, and Datums}

\begin{tabular}{|c|c|c|}
\hline Multiply & By & To obtain \\
\hline \multicolumn{3}{|c|}{ Length } \\
\hline inch (in.) & 2.54 & centimeter $(\mathrm{cm})$ \\
\hline foot $(\mathrm{ft})$ & 0.3048 & meter $(\mathrm{m})$ \\
\hline micron $(\mu \mathrm{m})$ & $3.937 \times 10^{-5}$ & inch (in.) \\
\hline mile (mi) & 1.609 & kilometer $(\mathrm{km})$ \\
\hline \multicolumn{3}{|c|}{ Area } \\
\hline acre & 0.4047 & hectare (ha) \\
\hline acre & 0.004047 & square kilometer $\left(\mathrm{km}^{2}\right)$ \\
\hline square foot $\left(\mathrm{ft}^{2}\right)$ & 0.09290 & square meter $\left(\mathrm{m}^{2}\right)$ \\
\hline square mile $\left(\mathrm{mi}^{2}\right)$ & 259.0 & hectare (ha) \\
\hline square mile $\left(\mathrm{mi}^{2}\right)$ & 2.590 & square kilometer $\left(\mathrm{km}^{2}\right)$ \\
\hline \multicolumn{3}{|c|}{ Mass } \\
\hline $\operatorname{gram}(\mathrm{g})$ & 0.03527 & ounce $(\mathrm{oz})$ \\
\hline \multicolumn{3}{|c|}{ Volume } \\
\hline acre-foot (acre-ft) & 1,233 & cubic meter $\left(\mathrm{m}^{3}\right)$ \\
\hline \multicolumn{3}{|c|}{ Rate } \\
\hline inch per hour (in/h) & 2.54 & centimeter per hour $(\mathrm{cm} / \mathrm{h})$ \\
\hline
\end{tabular}

Temperature in degrees Celsius $\left({ }^{\circ} \mathrm{C}\right)$ may be converted to degrees Fahrenheit $\left({ }^{\circ} \mathrm{F}\right)$ as follows:

$$
{ }^{\circ} \mathrm{F}=\left(1.8 \times^{\circ} \mathrm{C}\right)+32 \text {. }
$$

Temperature in degrees Fahrenheit $\left({ }^{\circ} \mathrm{F}\right)$ may be converted to degrees Celsius $\left({ }^{\circ} \mathrm{C}\right)$ as follows:

$$
{ }^{\circ} \mathrm{C}=\left({ }^{\circ} \mathrm{F}-32\right) / 1.8 \text {. }
$$

Vertical coordinate information is referenced to the North American Vertical Datum of 1988 (NAVD 88) or the National Geodetic Vertical Datum of 1929 (NGVD 29).

Horizontal coordinate information is referenced to the North American Datum of 1983 (NAD 83).

Elevation, as used in this report, refers to distance above the vertical datum. 


\title{
Estimation of Sediment Sources Using Selected Chemical Tracers in the Perry Lake and Lake Wabaunsee Basins, Northeast Kansas
}

\author{
By Kyle E. Juracek and Andrew C. Ziegler
}

\section{Abstract}

In Kansas and nationally, stream and lake sediment is a primary concern as related to several important issues including water quality and reservoir water-storage capacity. The ability to achieve meaningful decreases in sediment loads to reservoirs requires a determination of the relative importance of sediment sources within the contributing basins. To investigate sources of sediment within the Perry Lake and Lake Wabaunsee Basins of northeast Kansas, representative samples of channel-bank sources, surface-soil sources (cropland and grassland), and reservoir bottom sediment were collected, analyzed, and compared. Subbasins sampled within the Perry Lake Basin included Atchison County Lake, Banner Creek Reservoir, Gregg Creek, Mission Lake, and Walnut Creek. The samples were sieved to isolate the less than 63-micron fraction (that is, the silt and clay) and analyzed for selected nutrients (total nitrogen and total phosphorus), organic and total carbon, 25 trace elements, and the radionuclide cesium-137 $\left({ }^{137} \mathrm{Cs}\right)$.

To determine which of the 30 constituents provided the best ability to discriminate between channel-bank and surface-soil sources in the two basins, four selection criteria were used. To be selected, it was required that the candidate constituent (1) was detectable, (2) had concentrations or activities that varied substantially and consistently between the sources, (3) had concentration or activity ranges that did not overlap between the sources, and (4) had concentration or activity differences between the sources that were statistically significant.

On the basis of the four selection criteria, total nitrogen (TN), total phosphorus (TP), total organic carbon (TOC), and ${ }^{137} \mathrm{Cs}$ were selected. Of the four selected constituents, ${ }^{137} \mathrm{Cs}$ likely is the most reliable indicator of sediment source because it is known to be conservative in the environment. Trace elements were not selected because concentrations in the channel-bank and surface-soil sources generally were similar or did not vary in a consistent manner. To further account for differences in particle-size composition between the sources and the reservoir bottom sediment prior to the sediment-source estimations, constituent ratio and clay-normalization techniques were used. Computed ratios included the ratio of TOC to TN, TOC to TP, and TN to TP. Constituent concentrations (TN, TP,
TOC) and activities $\left({ }^{137} \mathrm{Cs}\right)$ were normalized by dividing by the percentage of clay. Thus, the sediment-source estimations involved the use of seven sediment-source indicators (that is, three constituent ratios and the clay-normalized concentration or activity for four constituents).

Sediment-source estimation for each reservoir was based on a comparison between the reservoir bottom sediment and the end member channel-bank and surface-soil sources. Within the Perry Lake Basin, the seven-indicator consensus indicated that both channel-bank and surface-soil sources were important contributors of the sediment deposited in Atchison County Lake and Banner Creek Reservoir, whereas channel-bank sources were the dominant source of sediment for Mission Lake. On the sole basis of ${ }^{137} \mathrm{Cs}$ activity, surface-soil sources contributed the most sediment to Atchison County Lake, and channel-bank sources contributed the most sediment to Banner Creek Reservoir and Mission Lake. For Perry Lake, both the seven-indicator consensus and ${ }^{137} \mathrm{Cs}$ indicated that channelbank sources were dominant and that channel-bank sources increased in importance with distance downstream in the Perry Lake Basin. For Lake Wabaunsee, the seven-indicator consensus and ${ }^{137} \mathrm{Cs}$ indicated that both channel-bank and surface-soil sources were important. Given that the relative contribution of sediment from channel-bank and surface-soil sources can vary within and between basins and over time, basin-specific strategies for sediment management and monitoring are appropriate.

\section{Introduction}

Stream and lake sediment is a primary concern in Kansas and nationally as related to several important issues including water quality and reservoir water-storage capacity. Nationally, billions of dollars have been spent over the past several decades to control erosion and mitigate its effects (Pimentel and others, 1995; Morris and Fan, 1998). In 2005, the U.S. Department of Agriculture's (USDA) Natural Resources Conservation Service (NRCS) spent an estimated \$30 million in Kansas for programs that either directly or indirectly addressed soil erosion (Paul Gallagher, USDA NRCS, oral 
commun., 2005). Examples of attempts to reduce erosion and sediment loads in streams include the implementation of best management practices (BMPs) through USDA programs, the construction of small impoundments through various Federal and State programs, and the total maximum daily load (TMDL) process. For each water body that does not meet water-quality standards, a State is required by the Federal Clean Water Act of 1972 to develop a TMDL, which is an estimate of the maximum pollutant load (material transported during a specified time period) from point and nonpoint sources that a receiving water can accept without exceeding water-quality standards (U.S. Environmental Protection Agency, 1991).

Attempts to decrease sediment loads in streams continue despite the fact that a fundamental question remains unanswered. The question is whether the sediment load in streams originates mostly from the erosion of channel banks or surface soils within a basin. The determination of sediment sources is essential for the design of effective sediment management strategies to achieve meaningful reductions in sediment loads and yields (Collins and Walling, 2004; Walling, 2005). Reduction of sediment loads and yields will help improve the quality of the State's water for various uses as well as extend the life of the State's many reservoirs.

Perry Lake is a Federal impoundment on the Delaware River in Jefferson County, northeast Kansas (fig. 1). Completed in 1969 by the U.S. Army Corps of Engineers (USCOE), the reservoir is used for flood control, water supply, recreation, fish and wildlife habitat, water-quality control, and navigation supplementation (Ken Wade, U.S. Army Corps of Engineers, oral commun., 2005). The original design life for Perry Lake was 100 years (U.S. Army Corps of Engineers, 1973). On the basis of results of a sedimentation survey completed in 2001, Juracek (2003) estimated that about 23 percent of the original conservation-pool, water-storage capacity of the lake (about 243,000 acre-ft) was filled with sediment.

Lake Wabaunsee is an impoundment on an unnamed tributary to East Branch Mill Creek in Wabaunsee County, northeast Kansas (fig. 1). Completed in 1937 mostly by the Federal Works Progress Administration (Lake Wabaunsee Sportsmen Association, 1971), the reservoir is used for water supply and recreation (Lisa Cernich, city of Eskridge, oral commun., 2005).

To address the need for information about sediment sources for Kansas reservoirs, a 2-year study by the U.S. Geological Survey (USGS), done in cooperation with the Kansas Water Office and the Kansas Department of Health and Environment, was begun in 2004. The specific study objective was to ascertain if the majority of the sediment deposited in the reservoirs originated from the erosion of channel banks or surface soils within the contributing basins.

This report describes the estimation of sediment sources using selected chemical tracers within the Perry Lake and Lake Wabaunsee Basins of northeast Kansas (fig. 1). The estimates were accomplished by the analysis and comparison of representative samples of channel banks, surface soils (crop- land and grassland), and reservoir bottom sediment collected during March-May 2005.

Information in this report may be used to guide the development and implementation of sediment management strategies. From a national perspective, the methods and results presented in this report provide guidance and perspective for future reservoir studies concerned with the determination and management of sediment sources.

\section{Description of Reservoir Basins}

\section{Perry Lake}

The Perry Lake Basin, which is essentially synonymous with the Delaware River Basin (except for the $12 \mathrm{mi}^{2}$ area located downstream from the dam), is an area of $1,117 \mathrm{mi}^{2}$ that drains part of northeast Kansas (fig. 2). In 1990, Perry Lake had a surface area of about 11,150 acres and a waterstorage capacity of about 209,500 acre-ft at the conservationpool elevation of $891.5 \mathrm{ft}$ above the NGVD of 1929 (Frank Funk, U.S. Army Corps of Engineers, oral commun., 2001). According to USCOE, the lake had an original surface area of about 12,200 acres and a water-storage capacity of about 243,000 acre- $\mathrm{ft}$ at the conservation-pool elevation (U.S. Army Corps of Engineers, 1973). The decreases in surface area and storage capacity are the result of ongoing sedimentation. In addition to the Delaware River, several small tributaries contribute flow directly to Perry Lake.

The Delaware River Basin is located within the Dissected Till Plains of the Central Lowland physiographic province (Fenneman, 1946; Schoewe, 1949) (fig. 1). This section is characterized by dissected deposits of glacial till that consist of silt, clay, sand, gravel, and boulders that overlie bedrock of primarily shale and limestone, with some sandstone (Jordan and Stamer, 1995). Maximum local relief is about $200 \mathrm{ft}$. Slopes in the basin range from nearly level to gently sloping on the flood plains and from gently sloping to steep in the uplands. Generally, slopes are less than 10 percent but locally may be as steep as 25 to 40 percent (U.S. Department of Agriculture, Soil Conservation Service, 1960, 1977, 1979, 1982, 1984). Slope, along with soil permeability and land use (discussed in the following paragraphs), are important determinants of storm runoff in a basin.

Typically, there is an inverse relation between soil permeability and runoff; that is, as soil permeability decreases, the potential for runoff increases. In the Delaware River Basin, depth-weighted, mean soil permeability averages about $0.5 \mathrm{in} / \mathrm{hr}$. In general, soil permeability is less in the uplands (typically $0.4 \mathrm{in} / \mathrm{hr}$ or less) and greater in the flood plains of the principal river and streams (typically 1.1 to $1.3 \mathrm{in} / \mathrm{hr}$ ) (Juracek, 2000). Soil erodibility is relatively uniform throughout the basin (U.S. Department of Agriculture, 1994).

Long-term mean annual precipitation in the Delaware River Basin ranges from about 35 in. at Horton, Kansas 


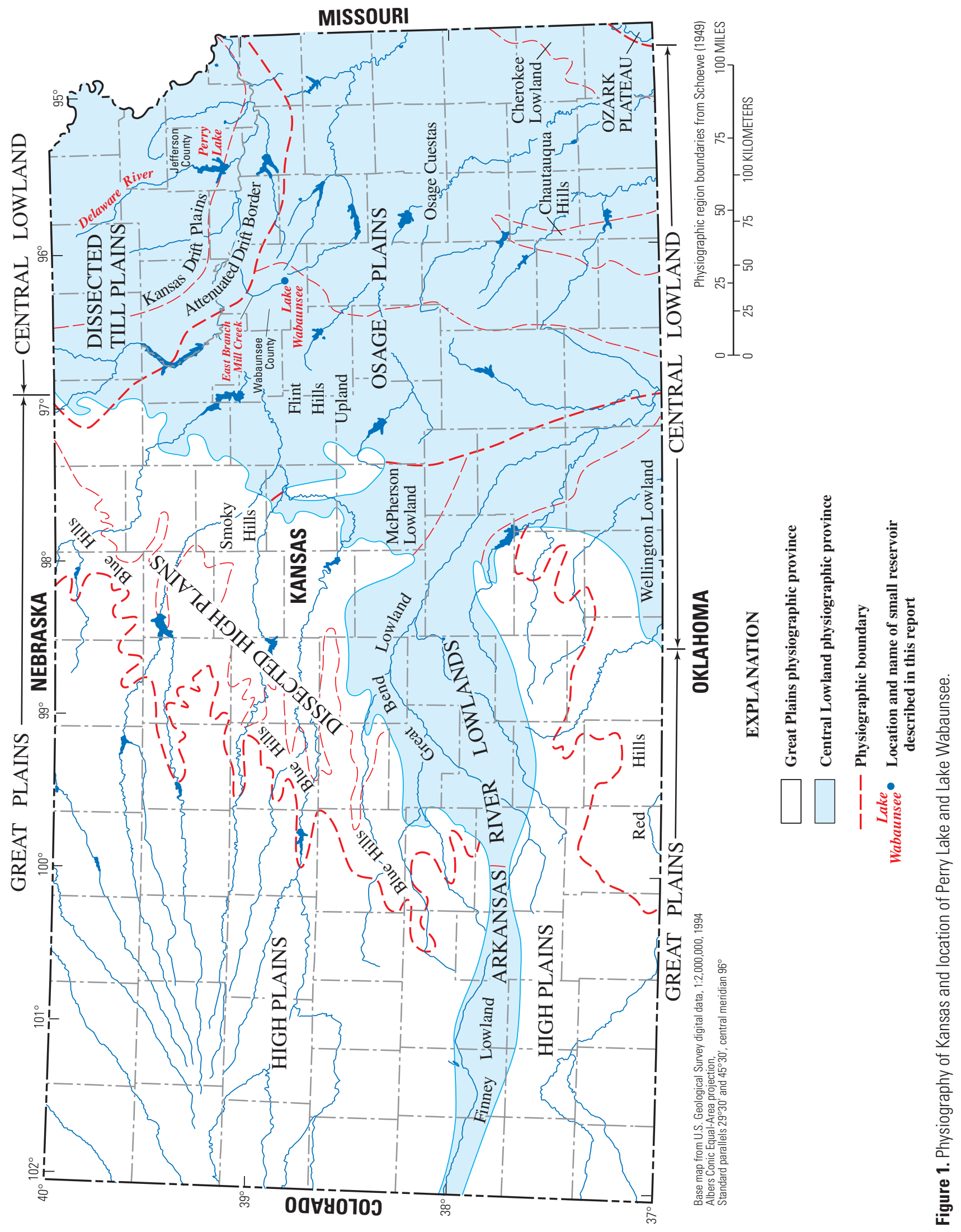




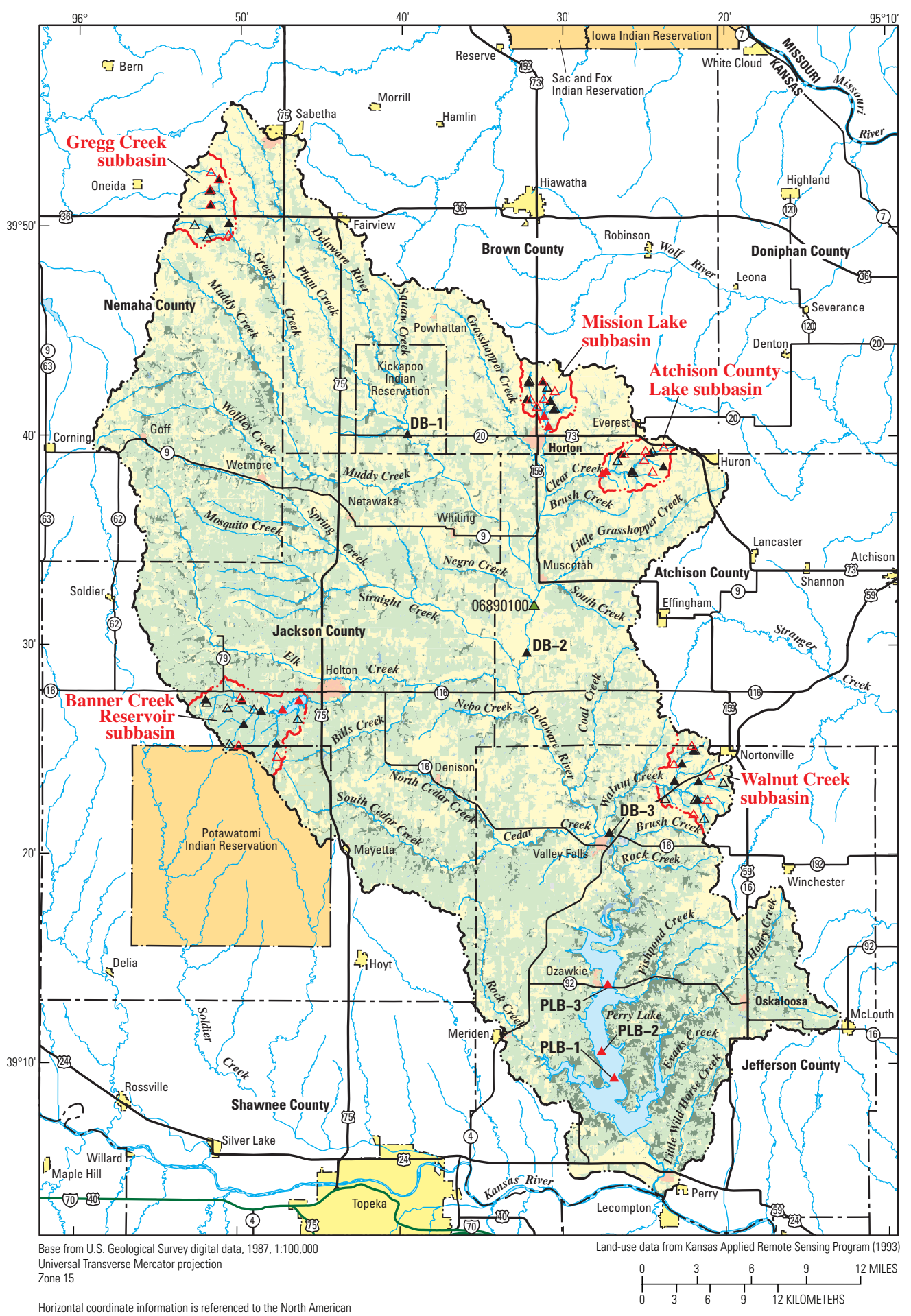

Datum of 1983 (NAD 83)

\section{EXPLANATION}

\begin{aligned} & \hline$\cdot \cdots-$ Boundary of Delaware River Basin \\ & BB-3 $\Delta \begin{array}{l}\text { Boundary of subbasin } \\ \text { Channel-bank sampling site and identifier } \\ \Delta\end{array} \\ & \Delta \begin{array}{l}\text { Cropland-soil sampling site } \\ \text { Grassland-soil sampling site } \\ \text { Reservoir bottom-sediment sampling site } \\ \text { and identifier }\end{array} \\ & \begin{array}{l}\text { U.S. Geological Survey gaging station } \\ \text { and number }\end{array}\end{aligned}$

Figure 2. Location of Delaware River Basin, Perry Lake, land use in the basin, the five subbasins selected for study, and location of channel-bank, cropland-soil, grassland-soil, and reservoir bottom-sediment sampling sites. 
Table 1. Land use in the Delaware River Basin, five selected subbasins within the Delaware River Basin, and the Lake Wabaunsee Basin, northeast Kansas, 1988-90.

[Land-use data from Kansas Applied Remote Sensing Program (1993). mi ${ }^{2}$, square miles]

\begin{tabular}{|c|c|c|c|c|c|c|c|c|}
\hline \multirow[b]{2}{*}{$\begin{array}{l}\text { Basin or subbasin } \\
\text { (figs. } 2 \text { and } 3 \text { ) }\end{array}$} & \multirow[b]{2}{*}{$\begin{array}{c}\text { Approxi- } \\
\text { mate basin } \\
\text { size }\left(\mathrm{mi}^{2}\right)\end{array}$} & \multicolumn{7}{|c|}{ Land use, in percentage of basin or subbasin } \\
\hline & & Cropland & Grassland & Woodland & Urban & Water & Other & $\begin{array}{c}\text { Ratio of } \\
\text { cropland to } \\
\text { grassland }\end{array}$ \\
\hline Delaware River ${ }^{1}$ & 1,129 & 40.3 & 49.6 & 7.2 & 0.5 & 2.3 & 0.1 & 0.8 \\
\hline Atchison County Lake & 9.3 & 75.6 & 21.9 & 1.0 & 0 & 1.4 & 0 & 3.5 \\
\hline Mission Lake & 8.6 & 70.2 & 24.9 & 1.3 & .3 & 3.1 & .1 & 2.8 \\
\hline Walnut Creek & 14.8 & 59.9 & 35.2 & 3.5 & 0 & 1.0 & .3 & 1.7 \\
\hline Lake Wabaunsee & 11.2 & .5 & 94.9 & .9 & 0 & 3.5 & .3 & .005 \\
\hline
\end{tabular}

${ }^{1}$ The Delaware River Basin includes the 1,117-mi² Perry Lake Basin.

(period of record 1900-2005), in the northern part of the basin, to about 38 in. at Oskaloosa, Kansas (period of record 1958-2005), in the south (High Plains Regional Climate Center, 2005). Most of the annual precipitation is received during the growing season (generally April-September).

Land use (1988-90) in the Delaware River Basin is mostly agricultural with grassland and cropland accounting for about 50 and 40 percent of the basin, respectively. Woodland accounts for about 7 percent of the basin. Urban land use occupies less than 1 percent of the basin (fig. 2, table 1) (Kansas Applied Remote Sensing Program, 1993).

\section{Lake Wabaunsee}

The Lake Wabaunsee Basin is an area of $11.2 \mathrm{mi}^{2}$ that drains part of south-central Wabaunsee County in northeast Kansas (fig. 1). In 1979, Lake Wabaunsee had a surface area of about 225 acres and a water-storage capacity of about 4,095 acre-ft (Lisa Cernich, city of Eskridge, written commun., 2005). Several small streams contribute flow directly to Lake Wabaunsee (fig. 3).

Physiographically, the Lake Wabaunsee Basin is located within the Flint Hills Upland of the Central Lowland physiographic province (Schoewe, 1949) (fig. 1). The topography of the Flint Hills Upland is characterized as gently rolling, and the underlying bedrock is mostly limestone and shale (Schoewe, 1949). Slopes in the Lake Wabaunsee Basin are generally 5 to 20 percent and sometimes less (U.S. Department of Agriculture, Soil Conservation Service, 1991). Depth-weighted, mean soil permeability in the Lake Wabaunsee Basin ranges from 0.3 to $1.3 \mathrm{in} / \mathrm{hr}$ with a mean of about $0.5 \mathrm{in} / \mathrm{hr}$ (Juracek, 2000). Land use (1988-90) in the Lake Wabaunsee Basin is mostly grassland (table 1).
Long-term mean annual precipitation at Eskridge, located about 4 mi east of Lake Wabaunsee, is about 36 in. (period of record 1948-2005) (High Plains Regional Climate Center, 2005). Most of the annual precipitation is received during the growing season (generally April-September).

\section{Acknowledgments}

This study was made possible in part by support from the Kansas State Water Plan Fund, the Kansas Water Office, and the Kansas Department of Health and Environment. The authors thank Dr. Arthur Horowitz (USGS), Dr. Jerry Ritchie (USDA, Agricultural Research Service), and Dr. Desmond Walling (University of Exeter, Exeter, Devon, United Kingdom) for their helpful discussions on study design. The authors also thank personnel with the USDA NRCS in Atchison, Brown, Jackson, Jefferson, Nemaha, and Wabaunsee Counties for their assistance in selecting sites for soil sampling. Finally, the authors thank Mark Bowen (University of Kansas) for his assistance in collecting the channel-bank and surface-soil samples.

\section{Methods}

The sediment deposited in a reservoir primarily originates from land-surface and channel sources in the contributing basin. Most of the deposited sediment consists of silt- and clay-sized particles, which are preferentially eroded and transported because of their small size. Differences in the composition of the source materials, compared to the deposited sediment, potentially can be used to estimate the relative importance (that is, in terms of the amount of sediment contributed) of the sources in a given basin. 


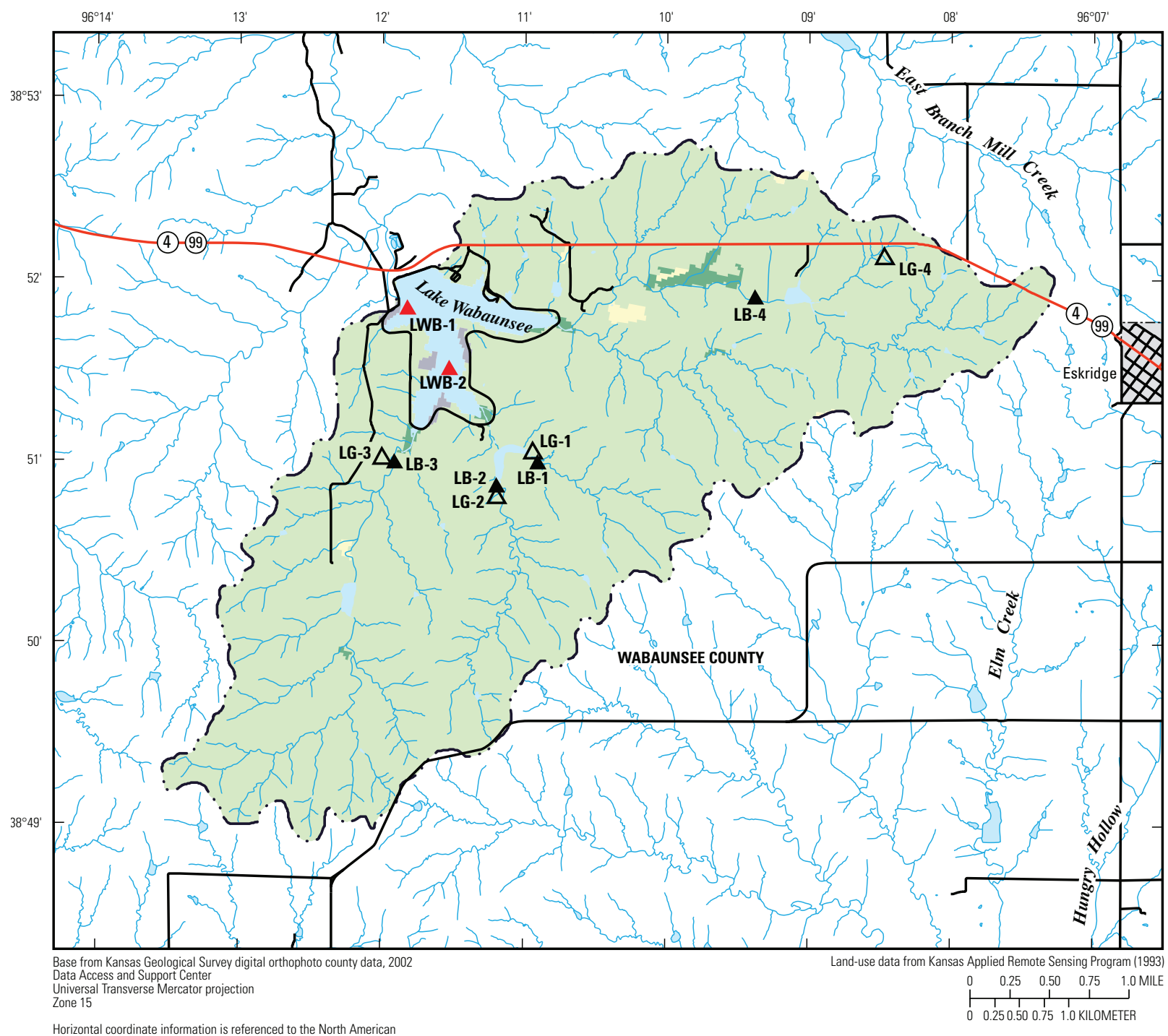

Horizontal coordinate information is referenced to the North American Datum of 1983 (NAD 83)

EXPLANATION

Land use

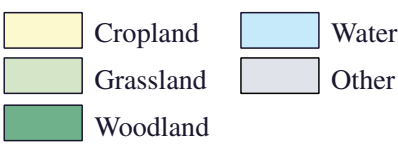

— - B Boundary of Lake Wabaunsee Basin

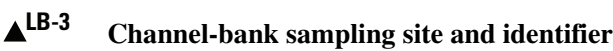

$\triangle^{\text {LG-1 }}$ Grassland-soil sampling site and identifier

$\triangle^{\text {LWB-1 }}$ Reservoir bottom-sediment sampling site and identifier

Figure 3. Location of Lake Wabaunsee Basin, Lake Wabaunsee, land use in the basin, and location of channel-bank, grassland-soil, and reservoir bottom-sediment sampling sites.

To estimate sediment sources in the Perry Lake and Lake Wabaunsee Basins, geographically representative samples of channel banks, surface soils (cropland and grassland), and recently deposited reservoir bottom sediment were collected, analyzed, and compared. Reservoir bottom sediment provides an integrated and representative sample of the sediment originating from the basin (Smol, 2002).

\section{Site Selection}

In both the Perry Lake and Lake Wabaunsee Basins, sites were selected to provide a geographically representative sample of conditions. Within the Perry Lake Basin, five subbasins selected for sampling also represented different land-use combinations. The subbasins selected were Atchison County 
Lake, Banner Creek Reservoir, Gregg Creek, Mission Lake, and Walnut Creek (fig. 2). The size of, and land use (1988-90) in, the five Perry Lake subbasins and the Lake Wabaunsee Basin are presented in table 1. Also, the channel banks of the main-stem Delaware River were sampled at three locations (fig. 2, sites DB-1, DB-2, DB-3).

Within the five Perry Lake subbasins and the Lake Wabaunsee Basin, three to five sampling sites were selected to represent each of the potential sources of sediment being investigated. Specifically, the sediment sources considered were channel banks, cropland soil, and grassland soil. Because the number of sampling sites was small, the representativeness of the samples for each sediment-source type was not tested statistically. Table 2 provides a summary of the number of samples collected and the number of samples analyzed for each sediment-source type in each basin. The location of the sampling sites in the Perry Lake and Lake Wabaunsee Basins is provided in figures $2-8$. The latitude and longitude for all sampling sites, obtained using global positioning system (GPS) technology, are provided in table A15 in the "Supplemental Information" section at the back of this report.

The small number of samples (three to five) used to characterize the channel-bank and surface-soil sources in each of the Perry Lake subbasins and the Lake Wabaunsee Basin is of possible concern. However, the collection of additional samples would not necessarily guarantee improved characterization. Presently, there are no guidelines for the optimum number of samples necessary to effectively characterize sediment sources (Collins and Walling, 2004).

For the cropland- and grassland-soil sampling sites, locations were selected that likely would contribute sediment to the nearby stream channel during storm runoff. Site

Table 2. Sediment-source type and number of samples collected and analyzed for the Perry Lake and Lake Wabaunsee Basins, northeast Kansas, March-May 2005.

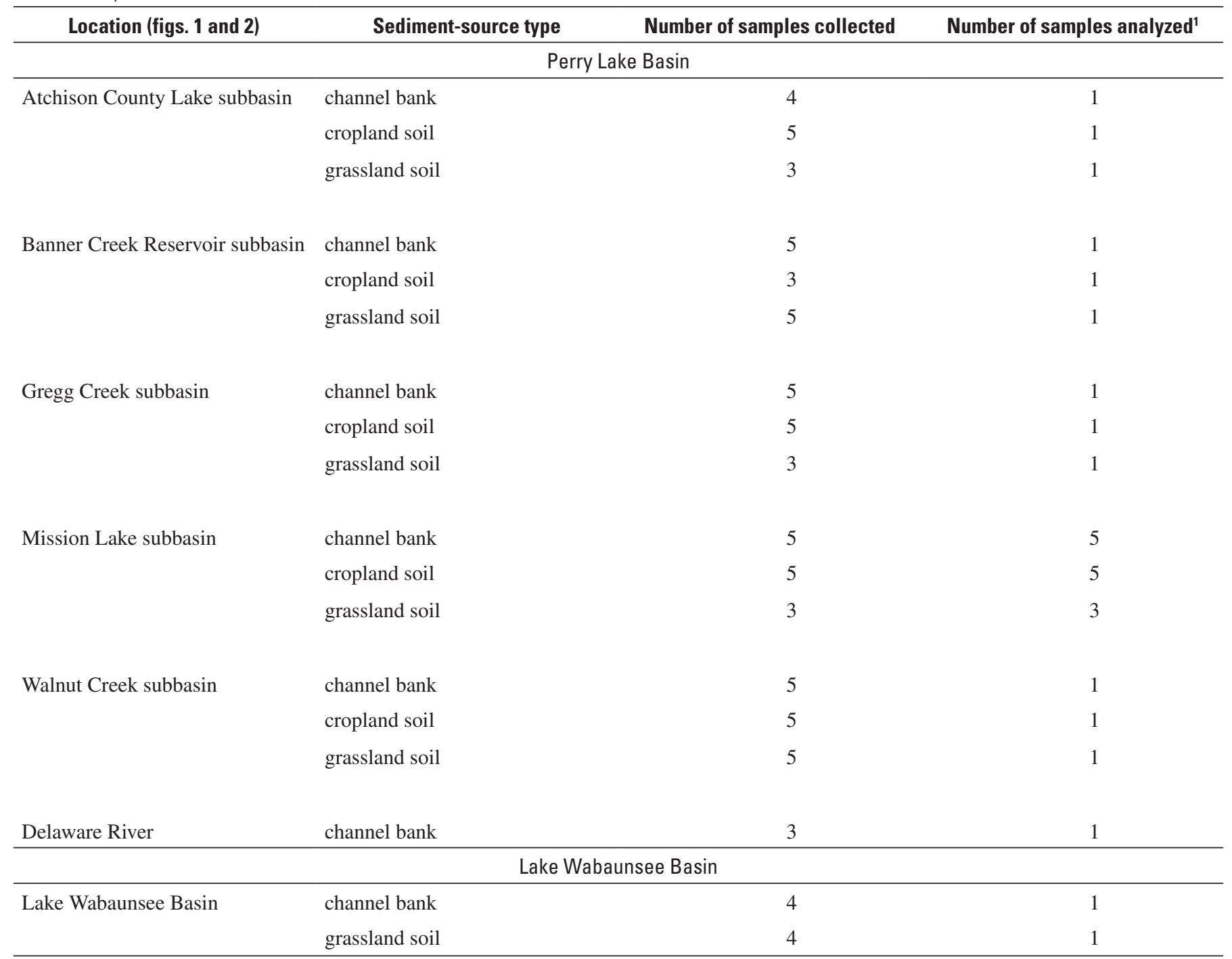

\footnotetext{
${ }^{1}$ With the exception of the Mission Lake subbasin samples, the samples collected for each location and sediment-source type were composited for subsequent constituent analyses.
} 


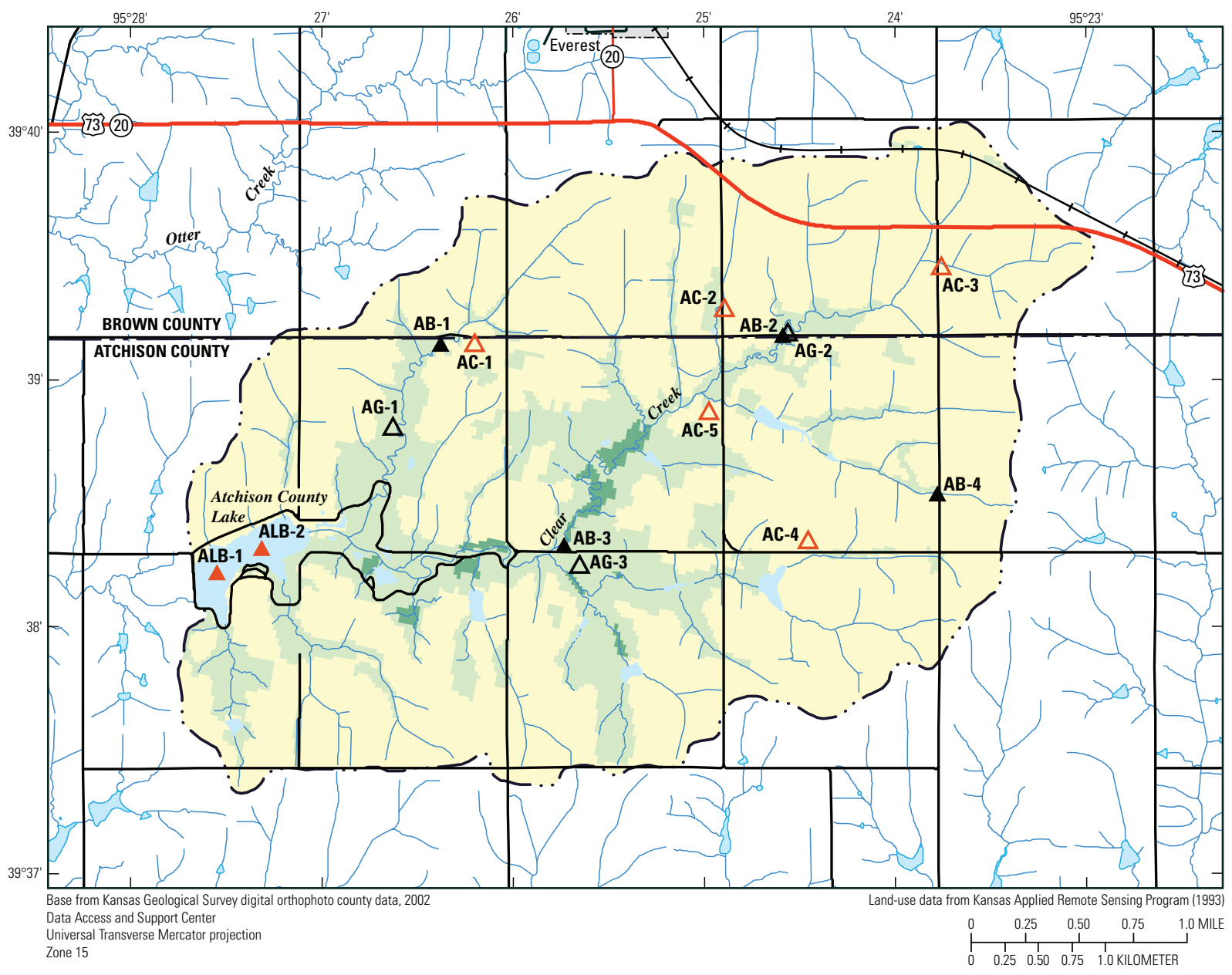

Horizontal coordinate information is referenced to the North American Datum of 1983 (NAD 83)

\section{EXPLANATION}

\begin{tabular}{|c|c|c|}
\hline Land use & $\cdots$ & Boundary of Atchison County Lake subbasin \\
\hline Cropland & $\mathbf{A}^{\mathrm{AB}-3}$ & Channel-bank sampling site and identifier \\
\hline Grassland & $\triangle^{\mathrm{AC}-3}$ & Cropland-soil sampling site and identifier \\
\hline Woodland & $\Delta^{\mathrm{AG-1}}$ & Grassland-soil sampling site and identifier \\
\hline Water & $\triangle A L B-1$ & Reservoir bottom-sediment sampling site and identifier \\
\hline
\end{tabular}

Figure 4. Location of Atchison County Lake subbasin, Atchison County Lake, land use in the subbasin, and location of channelbank, cropland-soil, grassland-soil, and reservoir bottom-sediment sampling sites.

selection included location in an area of the landscape that sloped toward a channel and from which any runoff would ultimately drain to the channel. Typically, each sampling site was located within $50 \mathrm{ft}$ upslope from a conduit (that is, a depression, ditch, gully, or tile drain) that would carry flow to the channel during storm runoff. In addition, the grassland sampling sites were selected at locations where continuous grassland existed for at least 30 years and typically longer.

Likewise, for the channel-bank sampling sites, locations were selected that likely would contribute sediment resulting from bank erosion. The sampling sites selected typically were cutbanks characterized by steep unvegetated slopes that exhibited evidence of active erosion (for example, exposed tree roots).

Reservoir bottom-sediment sampling sites were selected to assess the upstream-to-downstream variability in sediment composition within each reservoir. Two sites (that is, one in the downstream one-third and one in the upstream one-third of the reservoir) were sampled in Atchison County Lake, Banner Creek Reservoir, Lake Wabaunsee, and Mission Lake (figs. 3, 4, 5, and 7). Three sites were sampled in Perry Lake (fig. 2). Within each reservoir, the bottom-sediment samples were collected in relatively deep water where the sediment was least likely to be disturbed. 


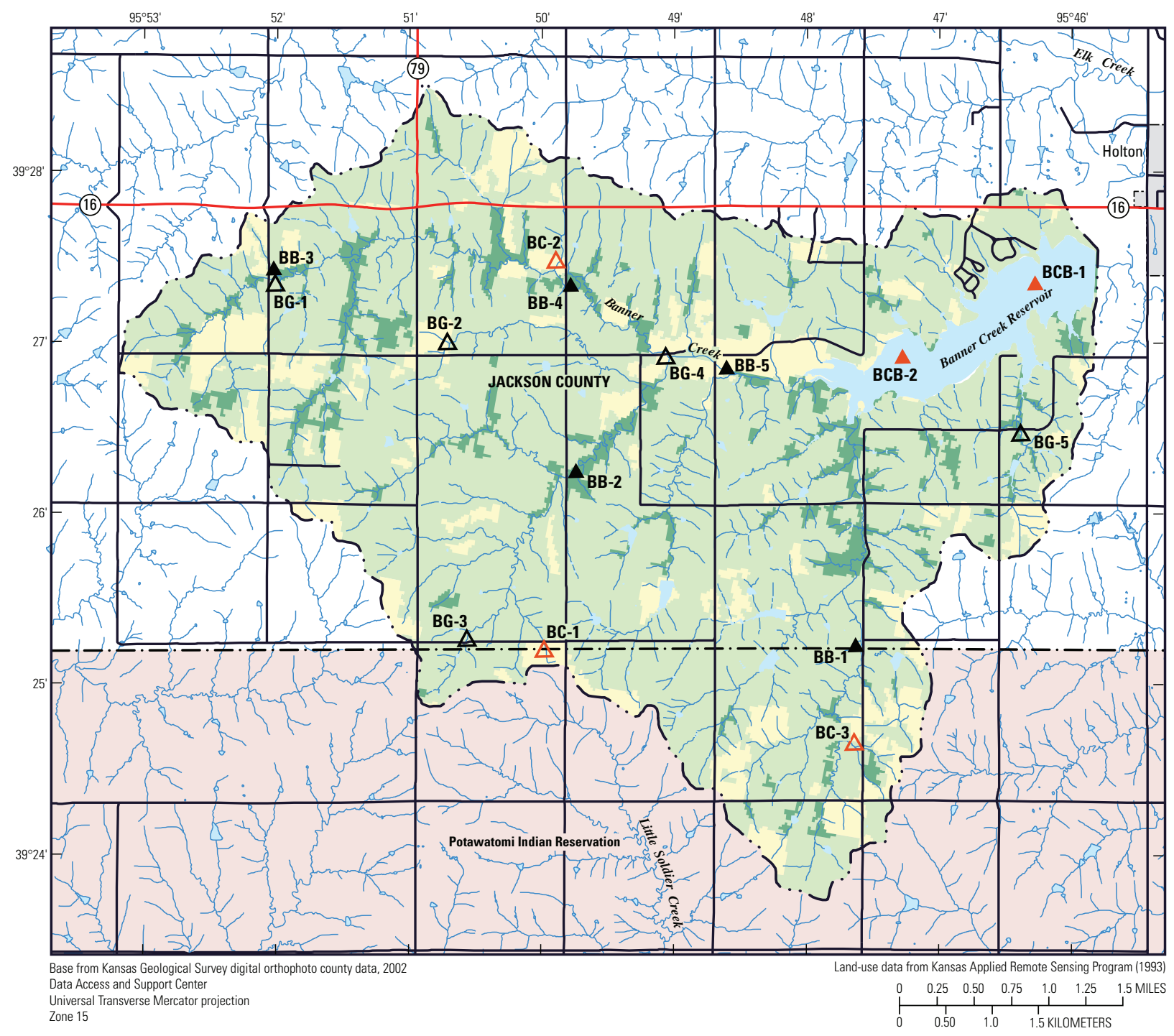

Horizontal coordinate information is referenced to the North American Datum of 1983 (NAD 83)

EXPLANATION
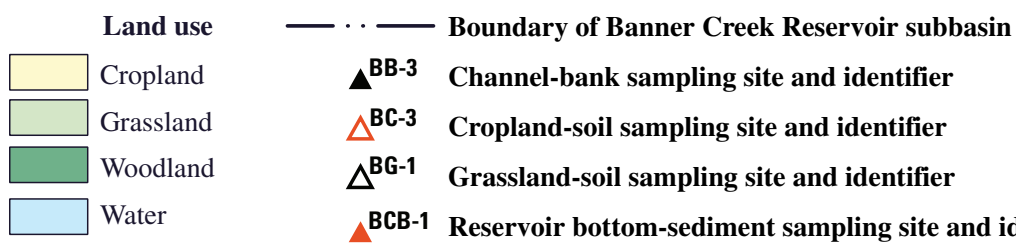

BCB-1 Reservoir bottom-sediment sampling site and identifier

Figure 5. Location of Banner Creek Reservoir subbasin, Banner Creek Reservoir, land use in the subbasin, and location of channelbank, cropland-soil, grassland-soil, and reservoir bottom-sediment sampling sites.

\section{Sample Collection}

All samples were collected in the spring of 2005 (MarchMay). Within the Perry Lake Basin, a total of 27 channelbank, 23 cropland-soil, 19 grassland-soil, and 9 reservoir bottom-sediment samples were collected (fig. 2, table 2). Within the Lake Wabaunsee Basin, a total of four channel-bank, four grassland-soil, and two reservoir bottom-sediment samples were collected (fig. 3, table 2). Channel-bank, cropland-soil, and grassland-soil samples were collected to a depth of about 1 in. (that is, horizontally into the channel banks and vertically into the soils) to obtain samples of material that were likely to be eroded (Collins and others, 1997a; Collins and Walling, 2002; Walling, 2005). The channel-bank samples were collected using a polished aluminum hand trowel. At each site, a vertical, unvegetated section of bank (that is, a cutbank) was 


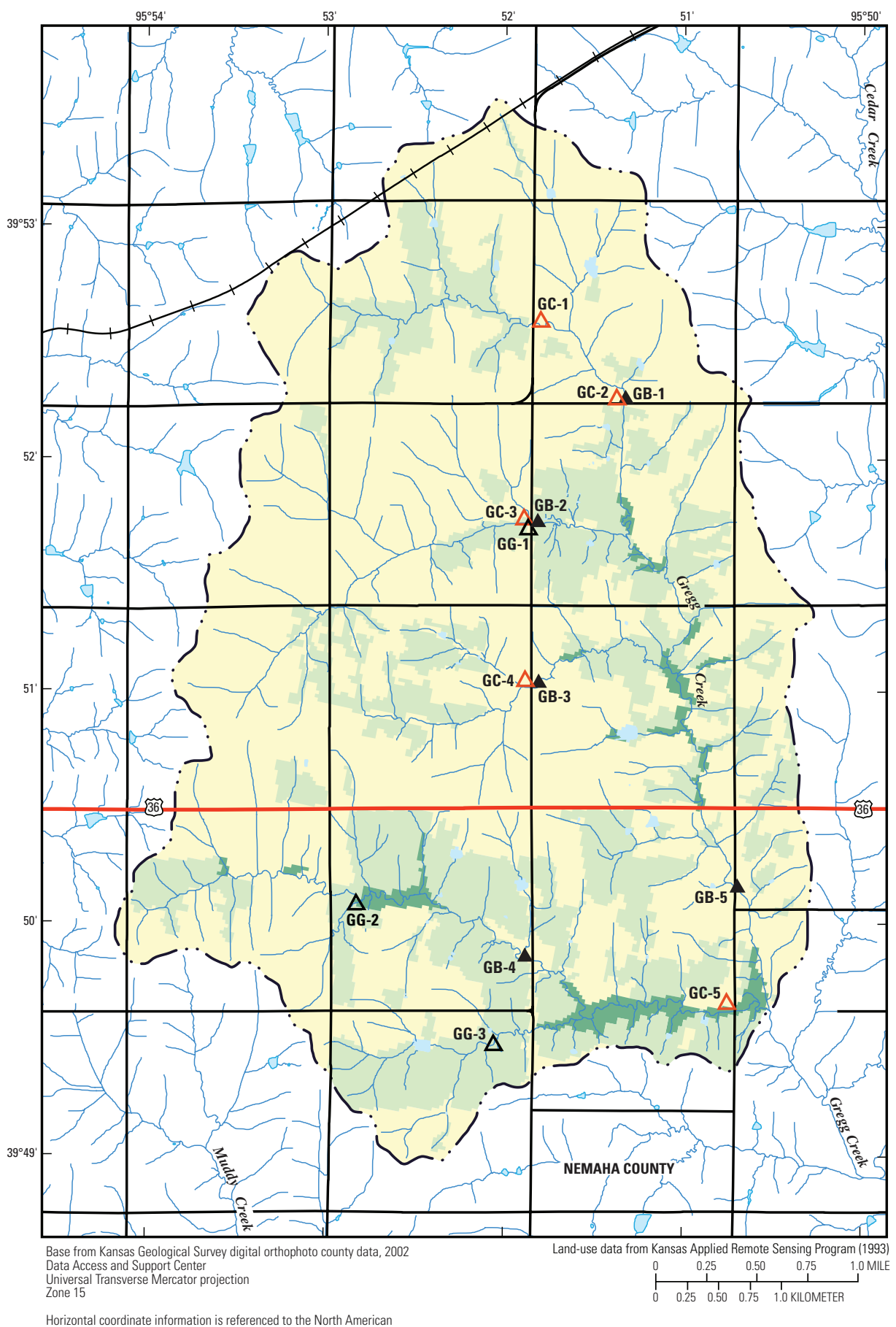

Horizontal coordinate information is referenced to the North American Datum of 1983 (NAD 83)

EXPLANATION

\begin{tabular}{|c|c|c|}
\hline Land use & 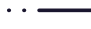 & Boundary of Gregg Creek subbasin \\
\hline Cropland & $\Delta^{\mathrm{GB}-3}$ & Channel-bank sampling site and identifier \\
\hline Grassland & $\Delta^{\mathrm{GC}-3}$ & Cropland-soil sampling site and identifier \\
\hline Woodland & $\Delta^{\mathrm{GG}-1}$ & Grassland-soil sampling site and identifier \\
\hline Water & & \\
\hline
\end{tabular}

Figure 6. Location of Gregg Creek subbasin, land use in the subbasin, and location of channel-bank, cropland-soil, and grassland-soil sampling sites. 


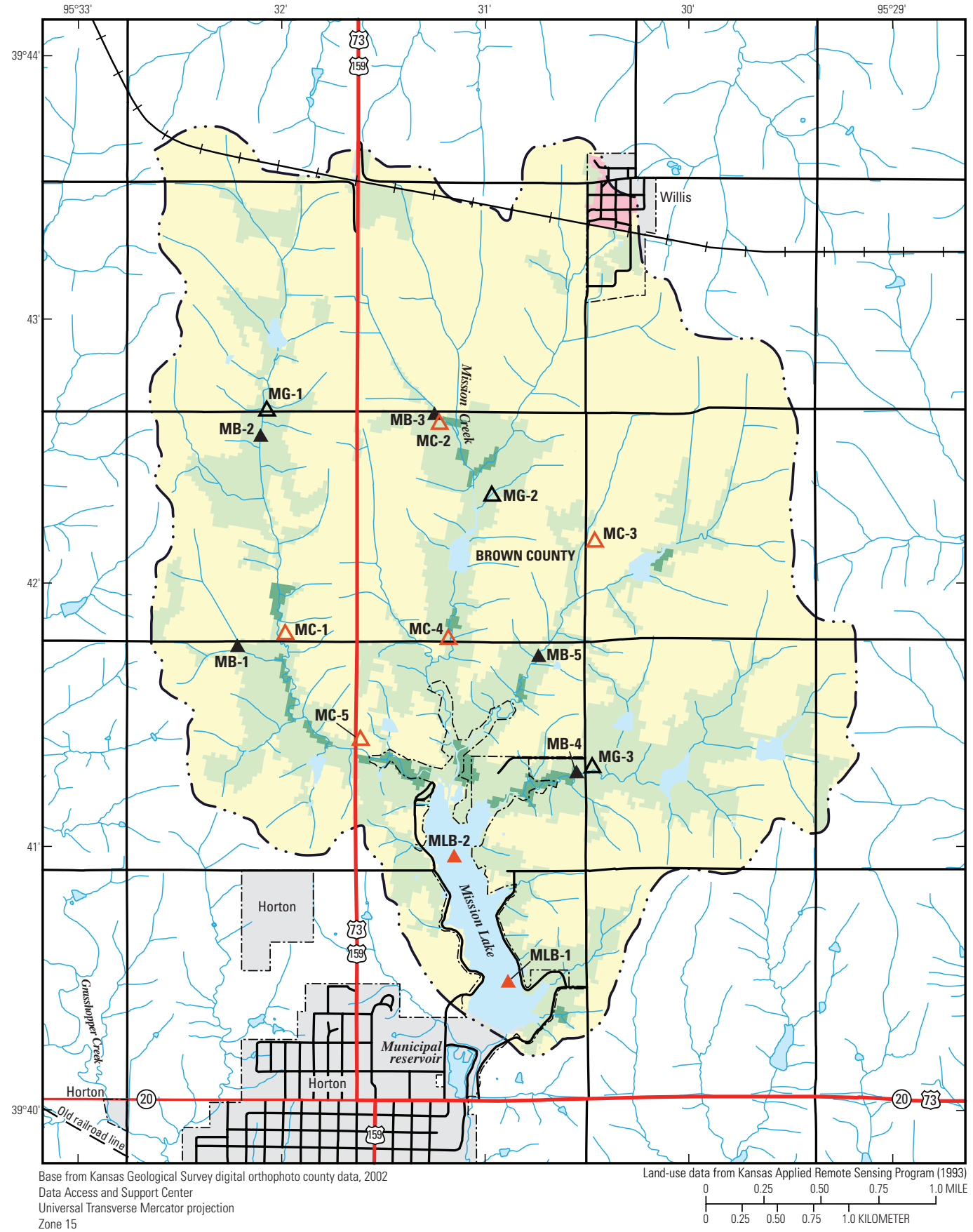

Horizontal coordinate information is referenced to the North American Datum of 1983 (NAD 83)

Land use

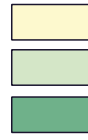

Cropland

Grassland

Woodland

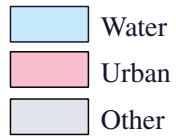

\section{EXPLANATION}

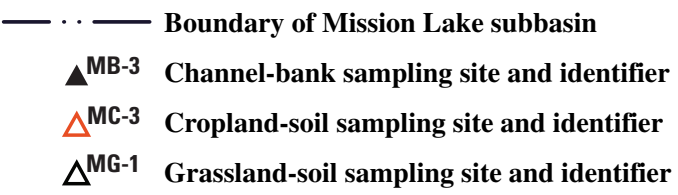

$\triangle^{\text {MLB-1 }}$ Reservoir bottom-sediment sampling site and identifier

Figure 7. Location of Mission Lake subbasin, Mission Lake, land use in the subbasin, and location of channel-bank, cropland-soil, grassland-soil, and reservoir bottom-sediment sampling sites. 


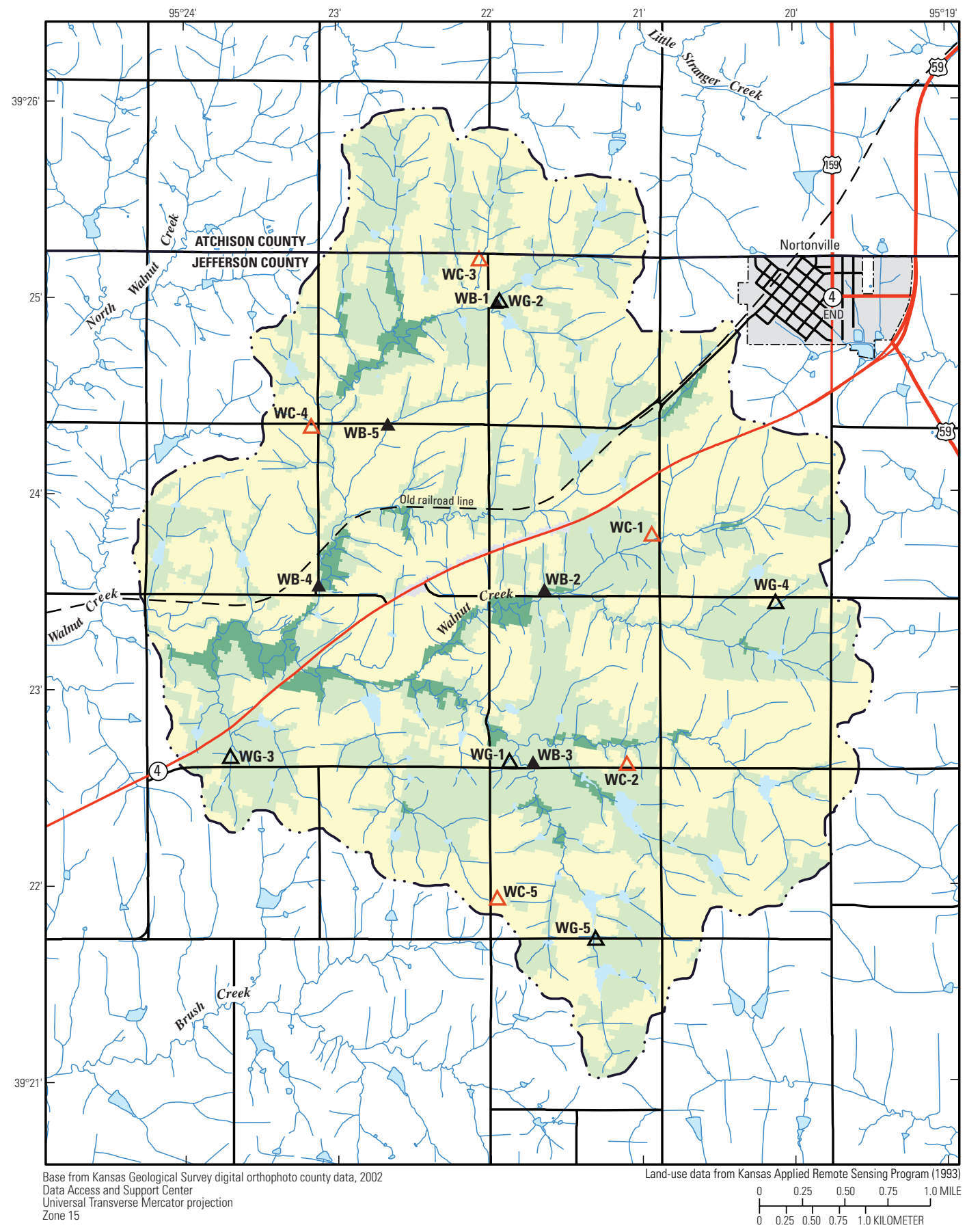

Horizontal coordinate information is referenced to the North American Datum of 1983 (NAD 83)

EXPLANATION

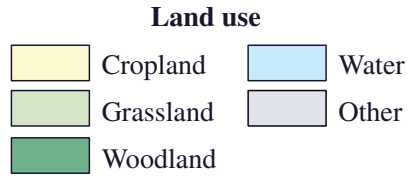
$\triangle^{\text {WB-3 }}$ Channel-bank sampling site and identifier $\triangle^{W C-3}$ Cropland-soil sampling site and identifier $\triangle^{W G-1}$ Grassland-soil sampling site and identifier

Figure 8. Location of Walnut Creek subbasin, land use in the subbasin, and location of channel-bank, cropland-soil, and grassland-soil sampling sites. 
selected for sampling. The objective of the sampling was to obtain a sample of the subsoil material in the bank that was expected to be chemically distinct from the overlying topsoil (Peart and Walling, 1986; Walling and Woodard, 1995). Generally, the middle one-third of the bank was sampled. Care was taken to avoid sampling the overlying topsoil by observing the depth of the topsoil (as frequently evidenced by a darker color and (or) the depth of the root zone). To provide a clean surface for sampling, part of the sampled interval sometimes required scrapping to remove material (for example, accumulations of loose particles or dried mud) that potentially contained topsoil. Also, the lower part of the sampled interval often had to be excavated to remove accumulated material at the base of the bank and expose a clean surface for sampling. The sample was collected along one or more vertical tracks in the bank. Each bank sample was stored in a plastic tub and transported back to the USGS laboratory in Lawrence, Kansas, for subsequent sample preparation.

At each cropland and grassland site, a representative location was selected for sample collection. The cropland-soil samples also were collected using a polished aluminum hand trowel. Collection of the grassland-soil samples was a twostep process. First, a steel spade was used to remove the sod from an area of about $1 \mathrm{ft}^{2}$ in size. Then, the soil sample was separated from the grass roots using the polished aluminum hand trowel. Each soil sample was stored in a plastic tub and transported back to the USGS laboratory in Lawrence, Kansas, for subsequent sample preparation.

The objective of the reservoir bottom-sediment sampling was to collect undisturbed surficial samples that represented the most recently deposited sediment (Foster and Walling, 1994; Zhang and Walling, 2005). To obtain these samples a box corer was used (Horowitz, 1991; Mudroch and Azcue, 1995). Lowered by rope from a boat, the box corer has a pinactivated steel jaw. When the corer encounters the lakebed, a tug of the rope releases the pin, and the steel jaw shuts thereby capturing a sample of the bottom sediment. The inside dimensions of the transparent plastic liner used in the box corer were $5.5 \mathrm{in}$. long by $5.5 \mathrm{in}$. wide by 8.0 in. deep. From each box core, the top (that is, most recently deposited) 1 in. of sediment was removed with a plastic spoon and placed in a plastic sample jar. The sediment samples were stored on ice and transported back to the USGS laboratory in Lawrence, Kansas, for subsequent sample preparation.

\section{Sample Preparation}

Preparation of the individual channel-bank, cropland-soil, and grassland-soil samples for subsequent constituent analyses involved several steps. Initially, each sample was emptied from the plastic tub onto a clean plastic sheet for examination and removal of unwanted components (for example, roots, sticks, grass, leaves, living organisms, and rocks). Then, the material was disaggregated and homogenized using the polished aluminum hand trowel. For the Mission Lake subbasin, the individual channel-bank, cropland-soil, and grassland-soil samples were analyzed separately to provide an indication of the spatial variability of the composition of the source materials. From each sample of prepared material, a subsample was removed and placed in a small plastic container for subsequent shipment to other laboratories for additional preparation and constituent analyses. For the remaining Perry Lake subbasins and the Lake Wabaunsee Basin, the individual channel-bank, cropland-soil, and grassland-soil samples were combined and analyzed as composite channel-bank, cropland-soil, and grassland-soil samples. Likewise, the channel-bank samples collected along the main-stem Delaware River were combined into one composite sample.

The composite samples required additional preparation. Prior to the compositing, the individual samples were disaggregated and homogenized. The composite sample was created by measuring an equal mass of material for each of the individual samples and then combining the material. For example, if five cropland sites were sampled for a basin, then $100 \mathrm{~g}$ (dry weight) of soil were measured for each individual sample and combined to create a 500-g composite cropland-soil sample. The composite sample was homogenized and placed in a small plastic container for subsequent shipment to other laboratories for additional preparation and constituent analyses. All of the reservoir bottom-sediment samples were homogenized and analyzed as individual samples.

All samples were sieved to isolate the less than $63-\mu \mathrm{m}$ fraction (that is, the silt and clay) for constituent analyses (Collins and others, 1997a; Nagle and Ritchie, 1999; Russell and others, 2001). This step was required to minimize potential bias in constituent concentrations that could be attributable to differences in the amount of coarse particles (for example, sand) in the samples. Also, the less than $63-\mu \mathrm{m}$ fraction is important because it is the most chemically active fraction of sediment (Horowitz, 1991). The samples were wet sieved at the USGS Sediment Trace Element Partitioning Laboratory in Atlanta, Georgia, according to the methods presented in Guy (1969). Additionally, the samples were analyzed for clay content at the USGS Earth Surface Processes Soils Laboratory in Denver, Colorado, using a laser analyzer (Harland Goldstein, USGS, written commun., 2006). Clay was defined as particles less than or equal to $3.9 \mu \mathrm{m}$ in size (Wentworth, 1922).

\section{Constituent Analyses}

The search for a single diagnostic sediment property has proven elusive, and recent studies have concluded that the use of multiple sediment properties is necessary to effectively discriminate between potential sediment sources (Russell and others, 2001; Collins and Walling, 2002). The use of multiple sediment properties provides a means of avoiding false source interpretations that may result from the use of a single property (Collins and others, 1997b). Ideally, such a composite tracer includes sediment properties from several different 
categories including organic constituents, trace elements, and radionuclides (Collins and Walling, 2002; Walling, 2005).

In this study, all samples were analyzed for nutrients (total nitrogen and total phosphorus), organic and total carbon, 25 trace elements, and the radionuclide cesium-137 $\left({ }^{137} \mathrm{Cs}\right)$. The sediment properties included in the analysis were chosen, in part, because they were shown to be effective in previous sediment-source studies (see discussion in following paragraphs). A complete list of the constituents for which analyses were performed is provided in table 3. Constituent analyses were performed at the USGS Sediment Trace Element Partitioning Laboratory in Atlanta, Georgia. Analyses of samples for total nitrogen and carbon concentrations were performed using the methods described by Horowitz and others (2001). Analyses for total phosphorus and trace elements were performed using the methods described by Fishman and Friedman (1989), Arbogast (1996), and Briggs and Meier (1999). Analysis of samples for ${ }^{137}$ Cs activity was performed at the USGS National Water-Quality Laboratory in Denver, Colorado, using gamma-ray spectrometry (American Society for Testing and Materials, 2004).

Both ${ }^{137} \mathrm{Cs}$ and total organic carbon (TOC) have been found to be useful as tracers to distinguish surface from channel-bank sources of sediment (Walling and Woodard, 1995; Zhang and Walling, 2005). A by-product of nuclear weapons testing, ${ }^{137} \mathrm{Cs}$ is a radioactive isotope that was deposited on the land surface by atmospheric fallout. Measurable activities of this isotope first appeared in about 1952, peaked during 1963-64, and have since declined. Upon reaching the soil surface, ${ }^{137} \mathrm{Cs}$ is strongly sorbed to the soil particles within the top few inches and generally does not migrate down through the soil profile (Ritchie and McHenry, 1990). The activity of ${ }^{137} \mathrm{Cs}$ in channel-bank materials tends to be substantially less than in surface soils due to the often near-vertical angle of the channel banks and the depth of the banks (relative to the surface soils), which typically exceeds the depth of ${ }^{137} \mathrm{Cs}$ penetration (He and Owens, 1995; Walling and Woodard, 1995). Although, where channel banks are shallow (for example, similar to or less than the depth of the surface soils), the activity of ${ }^{137} \mathrm{Cs}$ in the channel-bank materials may be similar to the surface soils.

TOC also is typically found in concentrations that are greatest at the surface and decline with depth in the soil profile and subsoil (Walling and Woodard, 1995; Jobbagy and Jackson, 2000). Therefore, surface-soil samples tend to have larger concentrations of TOC as compared to channel-bank samples. Other constituents, such as nitrogen, phosphorus, and various trace elements, also have been used for the purpose of estimating sediment sources in basins (Collins and Walling, 2002; Walling, 2005). In this study, a suite of 30 constituents was analyzed to determine which constituents were most useful for the purpose of discriminating sediment sources for reservoirs in northeast Kansas.

Table 3. Chemical analyses performed on channel-bank, cropland-soil, grassland-soil, and reservoir bottom-sediment samples from the Perry Lake and Lake Wabaunsee Basins, northeast Kansas.

[Number in parentheses is the method reporting limit for each constituent. $\mathrm{mg} / \mathrm{kg}$, milligrams per kilogram; \%, percent; pCi/g, picocuries per gram]

\begin{tabular}{|c|c|c|c|}
\hline \multicolumn{4}{|c|}{ Nutrients } \\
\hline \multicolumn{4}{|c|}{ Carbon } \\
\hline Carbon, total organic (TOC) $(0.1 \%)$ & Carbon, total $(0.1 \%)$ & & \\
\hline \multicolumn{4}{|c|}{ Trace elements } \\
\hline Arsenic $(0.1 \mathrm{mg} / \mathrm{kg})$ & Iron $(0.1 \%)$ & Silver $(0.5 \mathrm{mg} / \mathrm{kg})$ & Vanadium $(1.0 \mathrm{mg} / \mathrm{kg})$ \\
\hline Barium $(1.0 \mathrm{mg} / \mathrm{kg})$ & Lead $(1.0 \mathrm{mg} / \mathrm{kg})$ & Strontium $(1.0 \mathrm{mg} / \mathrm{kg})$ & Zinc (1.0 mg/kg) \\
\hline Beryllium $(0.1 \mathrm{mg} / \mathrm{kg})$ & Lithium $(1.0 \mathrm{mg} / \mathrm{kg})$ & Sulfur $(0.1 \%)$ & \\
\hline Cadmium $(0.1 \mathrm{mg} / \mathrm{kg})$ & Manganese $(10.0 \mathrm{mg} / \mathrm{kg})$ & Thallium $(50$ mg/kg) & \\
\hline
\end{tabular}

Radionuclide

Cesium-137 (0.04 pCi/g) ${ }^{1}$

${ }^{1}$ For cesium-137, a minimum detection concentration (MDC), rather than a method reporting limit, is reported. The MDC reported may vary because of several factors including the size of the sample. 


\section{Quality Control}

Quality control for the constituent analyses of sediment samples was provided by an evaluation of analytical variability. Analytical variability was evaluated through the splitreplicate analysis of the composite cropland-soil sample for the Atchison County Lake subbasin, the composite grasslandsoil sample for the Lake Wabaunsee Basin, and two bottomsediment samples for Perry Lake (sites PLB-2 and PLB-3) (fig. 2). Each pair of samples was prepared, as described previously, and analyzed for the various constituents. For each pair of samples, the relative percentage difference between the replicate sample concentrations was computed as:

$$
D_{\mathrm{rp}}=[|C 1-C 2| /(C 1+C 2)] * 100,
$$

where $D_{\mathrm{rp}} \quad$ is the relative percentage difference, C1 is the first replicate sample concentration, and $C 2$ is the second replicate sample concentration.

The relative percentage differences computed for all constituents detected in the split-replicate samples are provided in table 4 . With the exception of tin and ${ }^{137} \mathrm{Cs}$, analytical variability was minimal with relative percentage differences generally less than 5 percent. For tin, the relative percentage differences ranged from 16.1 to 33.3 percent with a mean of 20.7 percent. The relative percentage differences for ${ }^{137} \mathrm{Cs}$ ranged from 3.0 to 33.3 percent with a mean of 13.7 percent. The relatively large value of 33.3 percent for ${ }^{137} \mathrm{Cs}$ was attributed to the fact that the split-replicate samples for that site had activities ( 0.06 and $0.03 \mathrm{pCi} / \mathrm{g}$ ) that were very close to the most common detection limit $(0.04 \mathrm{pCi} / \mathrm{g})$. Excluding that site, the mean relative percentage difference for ${ }^{137} \mathrm{Cs}$ was 7.1 percent.

\section{Estimation of Sediment Sources}

The process of sediment-source estimation involved two steps. First, constituents were selected that clearly discriminated potential sources. Second, the selected constituents were used in a comparison between the potential sources and the reservoir bottom sediment to estimate the relative importance of individual sources (Collins and others, 1997b; Collins and Walling, 2002).

To select the constituents that provided a means for discriminating between channel-bank and surface-soil (that is, cropland and grassland) sediment sources, four criteria were used. A constituent was selected for use in the sedimentsource estimations if: (1) it was detected in the channel-bank and (or) surface-soil samples for the basins sampled; (2) the differences in the mean concentrations or activities between the sources were substantial (that is, at least 20 percent smaller or larger such that the differences could not be attributed to analytical variability) and consistent for the basins sampled; (3) the range of concentrations or activities for each source did not overlap with another source; and (4) the concentration or activity differences between the sources were statistically significant.

The third criterion was included because, if overlap exists between two sources, the candidate constituent can not be used to discriminate between those two sources. To assess overlap, the individual sampling sites within the Mission Lake subbasin were compared.

To determine if differences in constituent concentrations or activities among the sediment sources were statistically significant, nonparametric Wilcoxon rank-sum tests (Helsel and Hirsch, 1992) were performed. Specifically, the Wilcoxon rank-sum test was used to determine if statistically significant differences existed between the channel-bank and cropland sources, between the channel-bank and grassland sources, and between the cropland and grassland sources. Differences between two sources were considered to be statistically significant if the probability (two-sided p-value) of rejecting a correct hypothesis (in this case, no difference) was less than or equal to 0.05 . This analysis was performed for the five subbasins of the Perry Lake Basin.

The selected constituents were used in a subsequent analysis to estimate whether the majority of the reservoir bottom sediment originated from channel-bank or surface-soil sources within each basin or subbasin. The sediment-source estimations involved a comparison of the concentrations or activities for the selected constituents between the reservoir bottom sediment and the sediment sources for each reservoir. In this study, a sediment-source estimation was completed separately for Atchison County Lake, Banner Creek Reservoir, Mission Lake, Perry Lake, and Lake Wabaunsee.

\section{Constituents Selected for Sediment- Source Estimations}

Constituents used in the sediment-source estimations were selected on the basis of four criteria (fig. 9). The first selection criterion required that the candidate constituents be detected in the channel-bank and (or) surface-soil samples for all basins sampled. On the basis of this criterion, several trace elements were eliminated from further consideration. Molybdenum was eliminated because it was not detected in any of the samples from the Atchison County Lake and Mission Lake subbasins nor was it detected in the Lake Wabaunsee bottom sediment. Silver was eliminated because it was not detected in some or all samples for each basin or subbasin. Sulfur was eliminated because it was not detected in some of the samples for the Mission Lake subbasin. Finally, thallium and uranium were eliminated because they were not detected in any of the samples analyzed (tables A1-A7 in the "Supplemental Information" section at the back of this report).

The second selection criterion required that the candidate constituents had original concentrations or activities that were substantially (that is, smaller or larger by at least 20 percent) and consistently different among the sources (channel bank, 
Table 4. Relative percentage differences for constituent concentrations and cesium-137 activity in split-replicate samples of surface soil and bottom sediment from the Perry Lake and Lake Wabaunsee Basins, northeast Kansas, April and May 2005.

$[--$, not calculated $]$

\begin{tabular}{|c|c|c|c|c|c|}
\hline \multirow{2}{*}{ Constituent } & \multicolumn{5}{|c|}{ Relative percentage difference } \\
\hline & Site $\mathbf{A C}-\mathbf{C}^{1}$ & Site LG-C ${ }^{2}$ & Site PLB-2 ${ }^{3}$ & Site PLB-3 ${ }^{4}$ & Mean $^{5}$ \\
\hline \multicolumn{6}{|c|}{ Nutrients } \\
\hline Total phosphorus (TP) & 1.1 & .9 & 4.8 & 1.9 & 2.2 \\
\hline \multicolumn{6}{|c|}{ Carbon } \\
\hline \multicolumn{6}{|c|}{ Trace elements } \\
\hline Aluminum & 1.0 & 0 & 3.3 & 2.1 & 1.6 \\
\hline Antimony & 6.7 & 0 & 4.3 & 4.8 & 4.0 \\
\hline Arsenic & 4.1 & 2.0 & 2.7 & 4.3 & 3.3 \\
\hline Barium & .8 & 0 & 1.4 & 1.4 & .9 \\
\hline Chromium & 0 & 0 & 2.4 & .8 & .8 \\
\hline Cobalt & 0 & 0 & 3.2 & 3.4 & 1.7 \\
\hline Copper & 0 & 0 & 1.6 & 2.0 & .9 \\
\hline Iron & 0 & 0 & 2.0 & 2.9 & 1.2 \\
\hline Lead & 0 & 0 & 1.8 & 2.1 & 1.0 \\
\hline Lithium & 0 & 0 & 2.6 & 2.5 & 1.3 \\
\hline Manganese & 1.4 & 1.1 & 0 & 0 & .6 \\
\hline Molybdenum ${ }^{6}$ & -- & 0 & 0 & 0 & 0 \\
\hline Nickel & 0 & 2.3 & 2.4 & 3.1 & 2.0 \\
\hline Tin & 16.7 & 33.3 & 16.1 & 16.7 & 20.7 \\
\hline Titanium & 1.3 & 1.2 & 2.5 & 2.4 & 1.9 \\
\hline Uranium & -- & -- & -- & -- & -- \\
\hline Vanadium & 1.4 & 0 & 0 & 4.3 & 1.4 \\
\hline Zinc & 1.1 & .7 & 0 & 3.4 & 1.3 \\
\hline \multicolumn{6}{|c|}{ Radionuclide } \\
\hline Cesium-137 & 13.3 & 5.0 & 3.0 & 33.3 & 13.7 \\
\hline
\end{tabular}

${ }^{1}$ Composite cropland-soil sample for the Atchison County Lake subbasin.

${ }^{2}$ Composite grassland-soil sample for the Lake Wabaunsee Basin.

${ }^{3}$ Bottom-sediment sample collected at Perry Lake site PLB-2 (fig. 2).

${ }^{4}$ Bottom-sediment sample collected at Perry Lake site PLB-3 (fig. 2).

${ }^{5}$ Unless otherwise noted, the mean relative percentage difference reported is computed as the mean $(n=4)$ of the results for the four sampling sites for which split-replicate samples were analyzed.

${ }^{6}$ Mean relative percentage difference computed as the average for three sites. 


\section{Criterion} number

1.

2.

3.

4.
Selection criterion
Constituent detected in channel-bank and (or) surface-soil samples for all basins sampled?

\section{Constituents eliminated from further consideration}

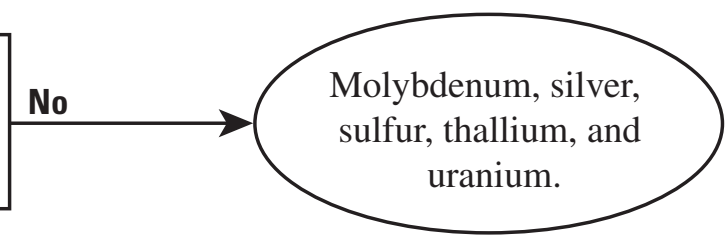

Yes

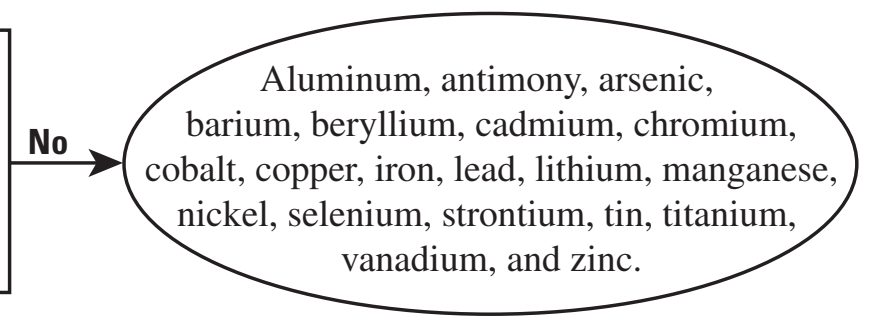

Substantial and consistent difference (at least 20 percent) in mean original concentration or activity among the channel-bank and surface-soil samples for all basins sampled?

Yes

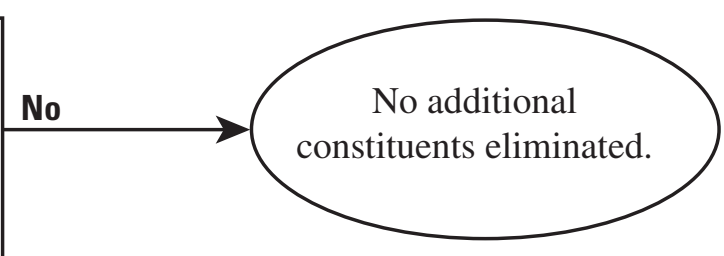
Lake subbasin?

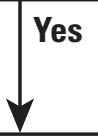

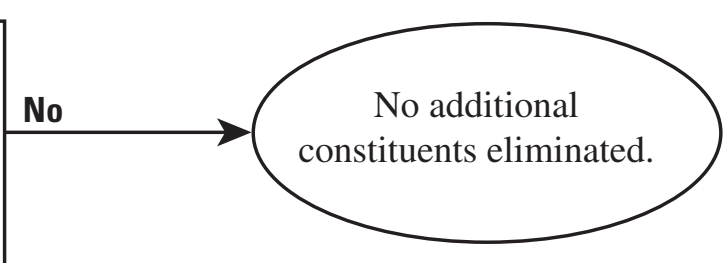

Yes

Total nitrogen, total phosphorus, total organic carbon, and cesium-137.

Figure 9. Flowchart showing criteria used to select constituents that discriminate between channel-bank and surface-soil sediment sources.

cropland soil, and grassland soil). On the basis of this criterion, the remaining trace elements were eliminated from further consideration because the original concentrations among the three sources generally were similar or did not vary in a consistent manner (tables A1-A7). However, four candidate constituents did satisfy the criterion-total nitrogen (TN), total phosphorus (TP), TOC, and ${ }^{137} \mathrm{Cs}$. For all four candidates, the original channel-bank concentrations or activities typically were substantially smaller than the original cropland-soil and grassland-soil concentrations or activities for all five Perry Lake subbasins (Atchison County Lake, Banner Creek Reservoir, Gregg Creek, Mission Lake, and Walnut Creek) and the Lake Wabaunsee Basin. Likewise, with a few exceptions, the original cropland-soil concentrations or activities were substantially smaller than the original grassland-soil concentrations or activities (table A8 in the "Supplemental Information" 
section at the back of this report). The exceptions included cropland-soil TP concentrations that were only modestly smaller than the grassland-soil concentrations (Banner Creek Reservoir, Mission Lake, and Walnut Creek subbasins), equivalent cropland-soil and grassland-soil TOC concentrations (Mission Lake subbasin), and similar ${ }^{137} \mathrm{Cs}$ activity (Mission Lake subbasin). Total carbon, which typically consists mostly of organic carbon, was eliminated from further consideration because it was considered to be redundant with TOC.

For TN, the composite cropland-soil samples from the five Perry Lake subbasins had original concentrations that averaged 190 percent more than the composite channel-bank samples. The composite grassland-soil samples from the five Perry Lake subbasins had original TN concentrations that averaged 340 percent more than the composite channel-bank samples. For the Lake Wabaunsee Basin, the original TN concentration for the composite grassland-soil sample was 870 percent more than the composite channel-bank sample. Composite grassland-soil samples from the five Perry Lake subbasins had original TN concentrations that averaged 57 percent more than the composite cropland-soil samples (table A8).

Original TP concentrations in the composite croplandsoil samples from the five Perry Lake subbasins averaged 43 percent more than the composite channel-bank samples. The 19-percent difference between the composite channelbank and cropland-soil samples for the Atchison County Lake subbasin was slightly less than the previously stated criterion of 20 percent. However, given that the criterion was somewhat arbitrary, the difference was considered to be sufficiently large. The composite grassland-soil samples from the five Perry Lake subbasins had original TP concentrations that averaged 69 percent more than the composite channel-bank samples. For the Lake Wabaunsee Basin, the original TP concentration for the composite grassland-soil sample was 41 percent more than the composite channel-bank sample. Composite grassland-soil samples from the five Perry Lake subbasins had original TP concentrations that averaged 21 percent more than the composite cropland-soil samples (table A8).

For TOC, the composite cropland-soil samples from the five Perry Lake subbasins had original concentrations that averaged 130 percent more than the composite channel-bank samples. The 17-percent difference between the composite channel-bank and cropland-soil samples for the Gregg Creek subbasin was slightly less than the previously stated criterion of 20 percent. However, given that the criterion was somewhat arbitrary, the difference was considered to be sufficiently large. The composite grassland-soil samples from the five Perry Lake subbasins had original TOC concentrations that averaged 240 percent more than the composite channel-bank samples. For the Lake Wabaunsee Basin, the original TOC concentration for the composite grassland-soil sample was 650 percent more than the composite channel-bank sample. Composite grassland-soil samples from the five Perry Lake subbasins had original TOC concentrations that averaged 60 percent more than the composite cropland-soil samples (table A8).
Original ${ }^{137} \mathrm{Cs}$ activity in the composite cropland-soil samples from the five Perry Lake subbasins was on average 470 percent more than the composite channel-bank samples. For the Walnut Creek subbasin, no ${ }^{137} \mathrm{Cs}$ activity was detected in the composite channel-bank sample. Thus, to enable the computation of percentage differences, the ${ }^{137} \mathrm{Cs}$ activity in this sample was arbitrarily assigned a value of $0.01 \mathrm{pCi} / \mathrm{g}$. The original ${ }^{137} \mathrm{Cs}$ activity in the composite grassland-soil samples from the five Perry Lake subbasins was on average 1,000 percent more than the composite channel-bank samples. For the Lake Wabaunsee Basin, the original ${ }^{137} \mathrm{Cs}$ activity for the composite grassland-soil sample was 3,700 percent more than the composite channel-bank sample. Composite grassland-soil samples from the five Perry Lake subbasins had original ${ }^{137} \mathrm{Cs}$ activity that averaged 150 percent more than the composite cropland-soil samples (table A8). The relative magnitudes of the ${ }^{137} \mathrm{Cs}$ activity measured for the channel-bank, croplandsoil, and grassland-soil sources in this study were consistent with results reported elsewhere (Ritchie and McHenry, 1990; Walling and Woodward, 1995; Zhang and Walling, 2005).

The third selection criterion required that the candidate constituents had concentration or activity ranges that did not overlap among the three sediment sources. Overlap was assessed by a comparison of the original constituent concentrations or activity for the individual channel-bank, croplandsoil, and grassland-soil sampling sites within the Mission Lake subbasin. For all four candidate constituents, the range in concentrations or activity for the channel-bank sampling sites was less than, and did not overlap with, the ranges in concentrations or activity for the cropland-soil and grasslandsoil sampling sites (table 5). This finding was important as it indicates that the four candidate constituents potentially may be useful for discriminating channel-bank from surface-soil sediment sources. The complete listings of original constituent concentrations and activity for all individual channel-bank, cropland-soil, and grassland-soil sampling sites in the Mission Lake subbasin are provided in tables A9, A10, and A11, respectively, in the "Supplemental Information" section at the back of this report.

Conversely, for all four candidate constituents, the range in concentrations and activity for the cropland-soil and grassland-soil sampling sites generally were similar with substantial overlap (table 5). This finding was important because it indicates that the four candidate constituents can not be used for the purpose of discriminating between cropland and grassland sediment sources in the Mission Lake subbasin. Elsewhere in the Perry Lake Basin, additional evidence of potential overlap between the cropland and grassland sediment sources was provided by the similarity of the mean TP concentrations for the Banner Creek Reservoir and Walnut Creek subbasins, the similarity of the mean TOC concentrations for the Banner Creek Reservoir subbasin, and the similarity of the mean ${ }^{137} \mathrm{Cs}$ activity for the Atchison County Lake subbasin. Possible overlap between the channel-bank and cropland sources was indicated by the similarity of the mean TOC concentrations and mean ${ }^{137} \mathrm{Cs}$ activity for the Gregg Creek subbasin (table A8). 
Table 5. Range in original total nitrogen, total phosphorus, and total organic carbon concentrations and cesium-137 activity for channel-bank, cropland-soil, and grassland-soil sampling sites in the Mission Lake subbasin, northeast Kansas, March-May 2005.

[mg/kg, milligrams per kilogram; \%, percent; $\mathrm{pCi} / \mathrm{g}$, picocuries per gram]

\begin{tabular}{|c|c|c|c|c|c|c|}
\hline \multirow{2}{*}{$\begin{array}{l}\text { Constituent and unit of } \\
\text { measurement }\end{array}$} & \multicolumn{2}{|c|}{$\begin{array}{c}\text { Channel-bank sampling site } \\
\text { concentrations }^{1}\end{array}$} & \multicolumn{2}{|c|}{$\begin{array}{c}\text { Cropland-soil sampling site } \\
\text { concentrations }^{1}\end{array}$} & \multicolumn{2}{|c|}{$\begin{array}{c}\text { Grassland-soil sampling site } \\
\text { concentrations }^{2}\end{array}$} \\
\hline & Minimum & Maximum & Minimum & Maximum & Minimum & Maximum \\
\hline Total nitrogen $(\mathrm{TN}), \mathrm{mg} / \mathrm{kg}$ & 260 & 1,000 & 1,400 & 3,800 & 1,800 & 3,200 \\
\hline Total phosphorus (TP), mg/kg & 360 & 410 & 490 & 820 & 510 & 720 \\
\hline Carbon (total organic, TOC), $\%$ & .3 & 1.3 & 1.6 & 4.3 & 1.9 & 2.7 \\
\hline Cesium-137, pCi/g & 0 & .07 & .11 & .35 & .11 & .36 \\
\hline
\end{tabular}

${ }^{1}$ Five sampling sites (fig. 7).

${ }^{2}$ Three sampling sites (fig. 7).

Because of the overlap between the cropland-soil and grassland-soil concentrations and activity for the four candidate constituents in the Mission Lake subbasin and potentially elsewhere, the two sources were combined into a single surface-soil sediment source. For each of the five Perry Lake subbasins, the cropland-soil and grassland-soil constituent concentrations and activity (table A8) were combined using a weighted averaging approach with land use (table 1) as the weighting factor. The computed surface-soil concentrations and activity for the four candidate constituents are provided in table A8.

The fourth selection criterion required that the candidate constituents had concentration or activity differences between the sediment sources that were statistically significant. To test for statistical significance, nonparametric Wilcoxon rank-sum tests were performed using the composite results for the five Perry Lake subbasins (table A8). For all four candidate constituents, the differences in mean concentrations and activity between the channel-bank and cropland sources, between the channel-bank and grassland sources, and between the channelbank and surface-soil sources (that is, the weighted average of the cropland and grassland sources) were significant at the 0.05 level. Differences between the cropland and grassland sources were significant at the 0.05 level for TN, TOC, and ${ }^{137} \mathrm{Cs}$. For TP, the differences between the cropland and grassland sources were significant at the 0.08 level.

On the basis of the four selection criteria, TN, TP, TOC, and ${ }^{137} \mathrm{Cs}$ were selected for use in an analysis to estimate whether the majority of the reservoir bottom sediment originated from channel-bank or surface-soil sources within each basin or subbasin. Of the four selected constituents, ${ }^{137} \mathrm{Cs}$ likely is the most reliable indicator of sediment source because it is known to be conservative in the environment (Ritchie and McHenry, 1990; Nagle and Ritchie, 1999; Motha and others, 2002). In other words, it is minimally affected by the processes of sediment generation and delivery. Conservative behavior is less certain for the other three constituents. For several constituents that have been used as tracers of sediment sources, additional research is needed to verify the assumption of conservative behavior (Collins and others, 1997a; Motha and others, 2002; Walling, 2005). Results of the sedimentsource estimations are presented in the following section.

\section{Sediment Sources in the Reservoir Basins}

Sediment is usually enriched in fine particles compared to the source materials (Walling, 1983; Walling and Woodward, 1992), and constituent concentrations and ${ }^{137} \mathrm{Cs}$ activity in sediment can be affected by differences in particle-size composition (Horowitz, 1991; He and Walling, 1996). For example, trace element concentrations typically increase as particle size decreases due, in part, to the increased surface area available for trace elements to accumulate (Horowitz, 1991). A particle-size or specific surface area normalization generally is required prior to sediment-source estimation and site-to-site or sample-to-sample comparisons. Sediment and source materials with differing particle-size compositions cannot be directly compared unless a normalization is used (Collins and others, 1997a). In this study, a partial particle-size normalization was done by sieving all samples to isolate the less than $63-\mu \mathrm{m}$ fraction prior to chemical analyses. However, particle-size effects still were indicated by the fact that constituent concentrations for the reservoir sediment samples frequently were substantially larger than the concentrations for the source samples. The suspected particle-size differences were confirmed by additional analyses that measured substantially larger clay contents in the reservoir sediment samples (tables A1, A2, A4, A6, and A7). Within each reservoir, the largest clay content was measured for the downstream sample(s). This pattern was consistent with the fact that reservoir sediment tends to become finer grained with distance downstream in a reservoir (Morris and Fan, 1998). To address the particle-size issue, two separate approaches were used-one involved the use of constituent ratios and the other a particle-size normalization. The 
resultant ratio and particle-size normalized data sets both were used for the purpose of estimating sediment sources.

Constituent ratios are less susceptible to apparent enrichment effects and may be directly compared without the need for a particle-size normalization provided that the constituents involved behave in the same way with respect to enrichment. Thus, the constituents used in a ratio should both be part of either the organic or inorganic fraction of the sediment (Walling and Kane, 1984). In this study, TOC:TN, TOC:TP, and TN:TP ratios (table A12 in the "Supplemental Information" section) were computed for use in the sediment-source estimations (Walling and Kane, 1984; Peart and Walling, 1986; D.E. Walling, University of Exeter, written commun., 2006).

The particle-size normalization was achieved by dividing the constituent concentrations (TN, TP, TOC) and activity $\left({ }^{137} \mathrm{Cs}\right)$ by the percentage of clay for each source and sediment sample (table A13 in the "Supplemental Information" section) (Horowitz, 1991; Collins and others, 1998; Walling and others, 1999; Gruszowski and others, 2003). Limitations of this type of particle-size normalization include the assumptions that: (1) all, or nearly all, of the constituents of interest are contained in the size fraction of interest (in this case, the clay fraction) (Horowitz, 1991); and (2) there is a linear relation between constituent concentration or activity and particle size (Russell and others, 2001). In sum, the sediment-source estimations involved the use of seven indicators (that is, three constituent ratios and the clay-normalized concentrations or activity for four constituents).

For the clay-normalized indicators to be valid for use in sediment-source estimation, it was required that their magnitude not be solely a function of particle size. In other words, if the indicators varied only in direct relation to clay content, they would not be valid for use in sediment-source estimation because actual differences in the composition of the sources do not exist. To verify the validity of the clay-normalized indicators, the coefficient of determination $\left(\mathrm{R}^{2}\right)$ was computed to assess the relation between percentage of clay and TN, TP, and TOC concentrations and ${ }^{137} \mathrm{Cs}$ activity for the Mission Lake channel-bank, cropland-soil, grassland-soil, and reservoir bottom-sediment samples. Respectively, the $\mathrm{R}^{2}$ values computed for the relation between percentage of clay and TN, TP, and TOC concentrations and ${ }^{137} \mathrm{Cs}$ activity were $0.006,0.39$, 0.0001 , and 0.0004 . Thus, given the apparent lack of a relation to percentage of clay, the four selected indicators were considered valid for use in sediment-source estimation in this study.

The particle-size normalization for clay content also was applied to the trace elements. Examination of the claynormalized trace element concentrations (tables A1-A7 in the "Supplemental Information" section) again indicated that the trace elements were not usable as indicators of sediment source because the concentrations among the sources generally were similar or did not vary in a consistent manner.

In addition to fine particles, sediment also is usually enriched in organic matter compared to the source materials (Walling, 1983), and constituent concentrations in sediment are affected by differences in organic matter content
(Horowitz, 1991). However, a normalization for organic matter content was not performed because the relation between it and constituent concentrations is complex and difficult to generalize and because enrichment in organic matter is closely related to enrichment in fine particles (Walling, 2005). The particlesize normalization likely accounts, in part, for differences in organic matter content (Russell and others, 2001).

In this study, the estimation of the relative importance of channel-bank and surface-soil sediment sources was based on a simple comparison of the composition of the two sources with the composition of the reservoir bottom sediment. Because the objective was to determine which of two sources was dominant, the use of a more sophisticated, multivariate sediment-mixing model (Collins and others, 1997a; Walling, 2005) was not necessary. For studies in which the objective is to quantify the contribution of sediment from three or more sources, use of a mixing model is required.

\section{Perry Lake}

Within the Perry Lake Basin, sediment-source estimations were completed separately for Atchison County Lake, Banner Creek Reservoir, and Mission Lake. Then, using the information from all five subbasins (fig. 2), a sediment-source estimation was completed for Perry Lake.

Differences in the relative contribution of sediment from channel-bank and surface-soil sources were indicated for the three small reservoirs. For Atchison County Lake, the seven sediment-source indicators indicated that both channel-bank and surface-soil sources contributed substantial sediment with the surface-soil sources possibly being the larger contributor (fig. 10). This conclusion was based on the fact that, for the seven indicators used, the two reservoir sediment samples typically were more similar to the surface-soil sources compositionally (that is, the reservoir sediment samples typically plotted closer to the surface-soil end member in figure 10). Cesium-137, which likely is the most reliable of the seven sediment-source indicators used, indicated that surface-soil sources were dominant in the subbasin (fig. 10, table 6).

For nearby Mission Lake (fig. 2), five of the seven sediment-source indicators (including ${ }^{137} \mathrm{Cs}$ ) indicated that most of the sediment originated from channel-bank sources (fig. 11, table 6). The difference in sediment sources between Atchison County Lake and Mission Lake is apparent despite the fact that the subbasins are very similar in most respects, including basin size and land use (table 1). In part, the difference may reflect differences in land-management practices and (or) the stability of the channel banks. For example, the amount of sediment derived from cropland will vary depending on several factors including soil type, slope, crop type, tillage practices, precipitation (timing, amount, intensity), and proximity to the stream-channel network. Likewise, the amount of sediment derived from channel banks will be affected by several factors including channel geometry, flow properties, bank composition, and vegetation (Knighton, 1998). 
A. Clay-normalized total nitrogen (TN) concentrations, in milligrams per kilogram

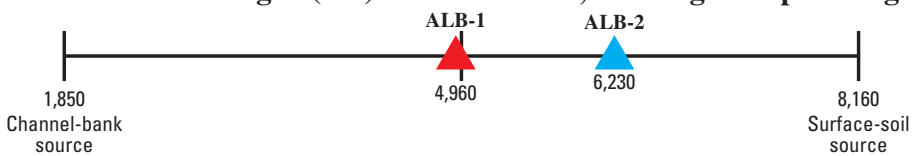

B. Clay-normalized total phosphorus (TP) concentrations, in milligrams per kilogram

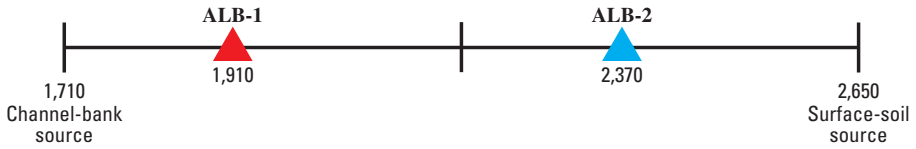

C. Clay-normalized total organic carbon (TOC) concentrations, in percent

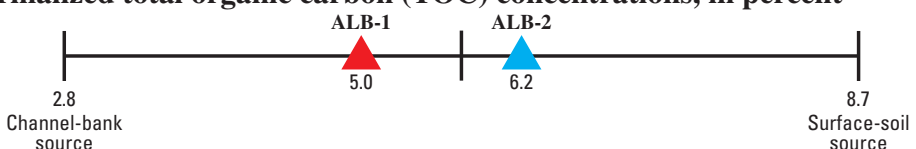

D. Clay-normalized cesium-137 activity, in picocuries per gram

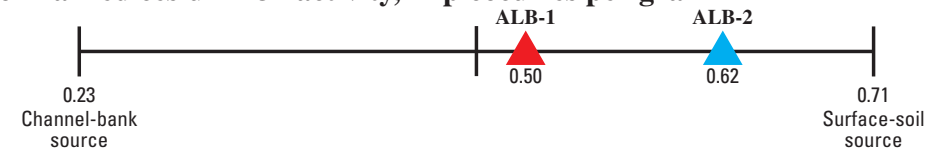

E. Ratio of TOC:TN

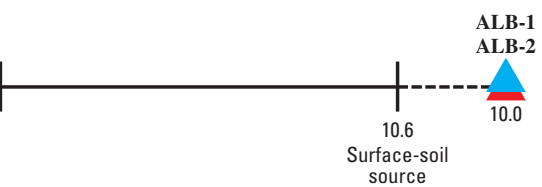

F. Ratio of TOC:TP

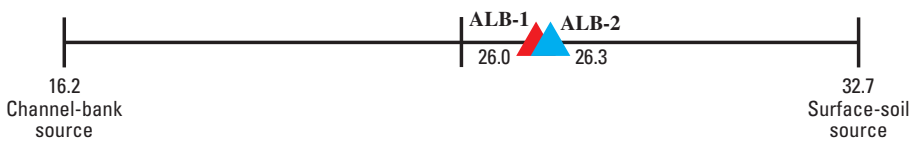

G. Ratio of TN:TP

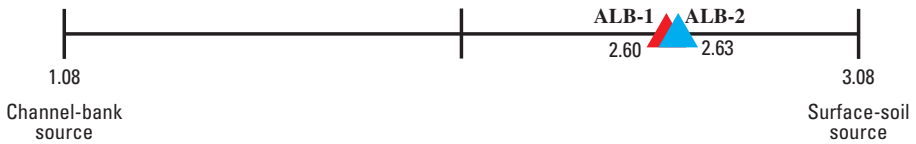

EXPLANATION

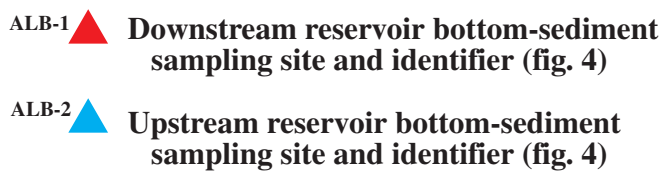

Note: Values indicate constituent concentration, activity, or ratio.

Figure 10. Comparison of channel-bank, surface-soil, and reservoir bottom-sediment composition using clay-normalized total nitrogen, total phosphorus, and total organic carbon concentrations, clay-normalized cesium-137 activity, and ratios of total organic carbon to total nitrogen, total organic carbon to total phosphorus, and total nitrogen to total phosphorus for Atchison County Lake, April and May 2005. Location of Atchison County Lake shown in figure 2. 
Table 6. Summary of sediment sources for reservoirs as indicated by clay-normalized constituents and constituent ratios.

[TN, total nitrogen; TP, total phosphorus; TOC, total organic carbon; ${ }^{137} \mathrm{Cs}$, cesium-137; S, surface-soil sediment sources were dominant; M, both sources contributed substantial sediment; M/S, both sources contributed substantial sediment but the surface-soil sources may be the larger contributor; B, channelbank sediment sources were dominant]

\begin{tabular}{|c|c|c|c|c|c|c|c|c|}
\hline \multirow{2}{*}{$\begin{array}{c}\text { Reservoir } \\
\text { (figs. } 1 \text { and 2) }\end{array}$} & \multicolumn{4}{|c|}{ Clay-normalized constituents ${ }^{1}$} & \multicolumn{3}{|c|}{ Constituent ratios $^{2}$} & \multirow{2}{*}{$\begin{array}{c}\text { Overall } \\
\text { assessmen }\end{array}$} \\
\hline & TN & TP & TOC & ${ }^{137} \mathrm{Cs}$ & TOC:TN & TOC:TP & TN:TP & \\
\hline Atchison County Lake & M & M & M & $S$ & $S$ & $\mathrm{~S}$ & $S$ & $\mathrm{M} / \mathrm{S}$ \\
\hline Mission Lake & $\mathrm{B}$ & $\mathrm{B}$ & B & B & $\mathrm{S}$ & $\mathrm{B}$ & M & $\mathrm{B}$ \\
\hline Perry Lake & $\mathrm{B}$ & B & B & B & $\mathrm{S}$ & B & B & $\mathrm{B}$ \\
\hline Lake Wabaunsee & $\mathrm{M}$ & M & M & M & $\mathrm{S}$ & M & M & M \\
\hline
\end{tabular}

${ }^{1}$ Constituent concentrations (TOC, TN, TP) and activity $\left({ }^{137} \mathrm{Cs}\right)$ normalized by percentage clay are provided in table A13 at the back of this report. Comparison of clay-normalized constituent concentrations and activities for the sediment sources and reservoir bottom sediment is provided in figures 10-14.

${ }^{2}$ Constituent ratios provided in table A12 at the back of this report. Comparison of constituent ratios for the sediment sources and reservoir bottom sediment is provided in figures $10-14$.

On the basis of the seven sediment-source indicators, both channel-bank and surface-soil sources contributed substantial sediment to Banner Creek Reservoir (fig. 12). ${ }^{137} \mathrm{Cs}$ activity indicated that channel-bank sources were the largest contributor of sediment to Banner Creek Reservoir (fig. 12, table 6) as was the case for Mission Lake. In addition to the factors previously cited, the differences among the three small reservoirs may reflect the fact that a small percentage of a basin can account for a large percentage of the sediment yield (Morris and Fan, 1998; Russell and others, 2001). It also is important to keep in mind that the relative contribution of various sediment sources likely will change over time.

According to six of the seven sediment-source indicators (including ${ }^{137} \mathrm{Cs}$ ), channel-bank sources were the dominant sediment source for Perry Lake (fig. 13, table 6). When compared to the results for the three small reservoirs, this finding indicated that channel-bank sources increased in importance with distance downstream in the Perry Lake Basin. The tendency for the contribution of sediment from channel erosion to become more important with distance downstream in a basin has been reported elsewhere (Knighton, 1998; Lawler and others, 1999; Walling, 2005).

Within the Perry Lake Basin, the relative contribution of sediment from the erosion of channel banks in the tributary streams compared to the main-stem Delaware River was uncertain. Compositionally, a comparison of the Delaware River channel-bank material with the channel-bank material sampled for the five subbasins indicated general similarity for the four selected constituents used in the sedimentsource determinations (tables A8 and A13). Table A14 in the "Supplemental Information" section provides the original and clay-normalized constituent concentrations and ${ }^{137} \mathrm{Cs}$ activity for the Delaware River channel-bank material.

Because channel-bank erosion inevitably mobilizes some surface soil (for example, material at the top of a cutbank), the composition of the bank-derived sediment may vary somewhat from the composition of the channel-bank sources determined on the basis of sampling that was limited to the subsurface part of the banks. Specifically, the concentration or activity for the four selected constituents may be somewhat larger for the bank-derived sediment than was indicated by the channelbank samples analyzed. It is not known if the compositional difference is significant or negligible. Thus, in a given basin, the contribution of sediment from channel-bank sources may or may not be somewhat larger than what was suggested by the composition of the reservoir bottom sediment. Additional research is needed to assess the compositional effect of partial versus complete channel-bank sampling.

Another uncertainty is the role of channel beds as a sediment source. The question is whether the beds are truly a source or just a temporary storage location from which the deposited sediment is subsequently remobilized and transported downstream. For the beds to be a true source, pronounced bed erosion (downcutting) would be required. This may be unlikely upstream from reservoirs because the reservoirs provide base-level control. At the gaging station on the Delaware River near Muscotah, Kansas (station 06890100, fig. 2), stage-discharge relations indicated that the channel bed at this location has been stable (that is, no downcutting) for at least the last 5 years. Thus, the alternate scenario of temporary storage and subsequent remobilization may be more likely. In this scenario, the original source of any fine-grained sediment (clay and silt) stored on the channel bed would be channel banks and surface soils. However, because minimal flow velocity is required to suspend and transport fine-grained particles, the bed sediment tends to consist mostly of coarser sand and gravel (as the fine particles are carried on downstream).

An additional complicating factor is shoreline erosion within Perry Lake, which may have contributed sediment that is chemically similar to channel-bank sources within the upstream basin. Sampling of actively eroding shoreline in Perry Lake was not included as part of this study. 
A. Clay-normalized total nitrogen (TN) concentrations, in milligrams per kilogram

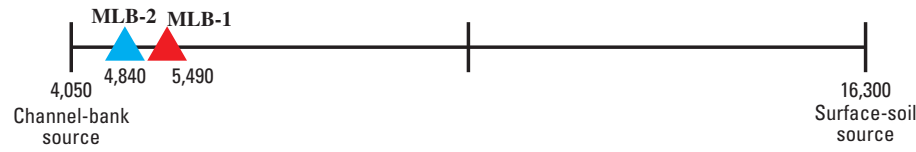

B. Clay-normalized total phosphorus (TP) concentrations, in milligrams per kilogram MLB-2

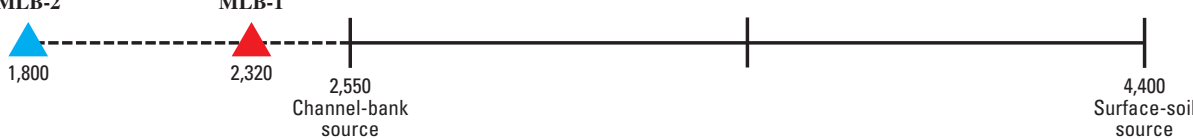

C. Clay-normalized total organic carbon (TOC) concentrations, in percent

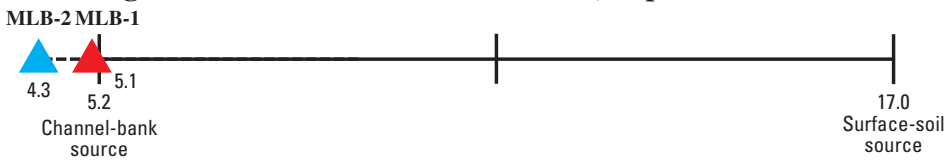

D. Clay-normalized cesium-137 activity, in picocuries per gram

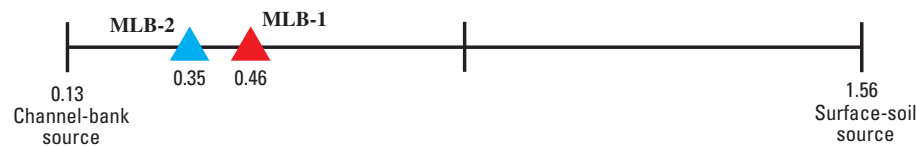

E. Ratio of TOC:TN

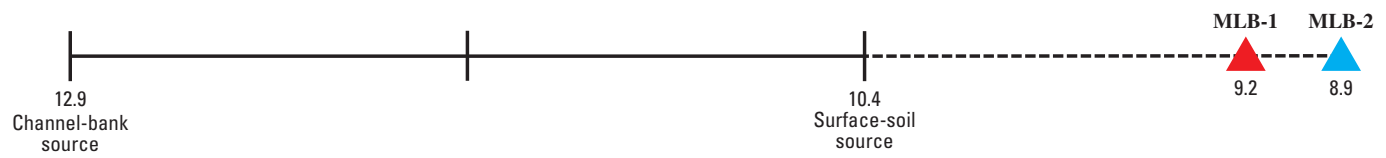

F. Ratio of TOC:TP

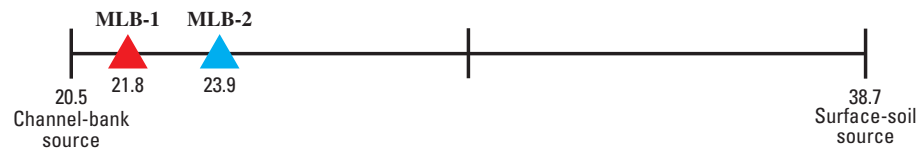

G. Ratio of TN:TP

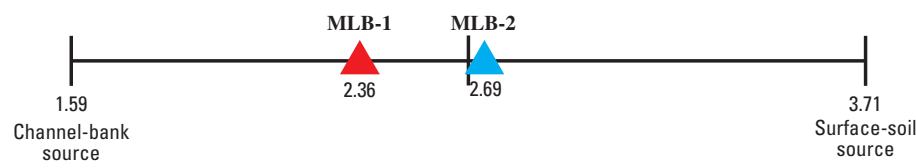

EXPLANATION

MLB-1

Downstream reservoir bottom-sediment sampling site and identifier (fig. 7)

MLB-2

Upstream reservoir bottom-sediment sampling site and identifier (fig. 7)

Note: Values indicate constituent concentration, activity, or ratio.

Figure 11. Comparison of channel-bank, surface-soil, and reservoir bottom-sediment composition using clay-normalized total nitrogen, total phosphorus, and total organic carbon concentrations, clay-normalized cesium-137 activity, and ratios of total organic carbon to total nitrogen, total organic carbon to total phosphorus, and total nitrogen to total phosphorus for Mission Lake, March-May 2005. Location of Mission Lake shown in figure 2.

In some cases, an indicator value (that is, a constituent ratio or a clay-normalized constituent concentration or activity) for the reservoir sediment was outside of the range of values provided by the end member channel-bank and surfacesoil sources (figs. 10-13). Several possible explanations, in part, may account for this situation including: (1) analytical variability; (2) use of composite samples to represent sources; (3) alteration during transport and (or) by in-lake geochemical processes; and (4) unsampled sources.

Because the relative contribution of sediment from channel-bank and surface-soil sources was shown to vary with location in the Perry Lake Basin, it follows that the 
A. Clay-normalized total nitrogen (TN) concentrations, in milligrams per kilogram

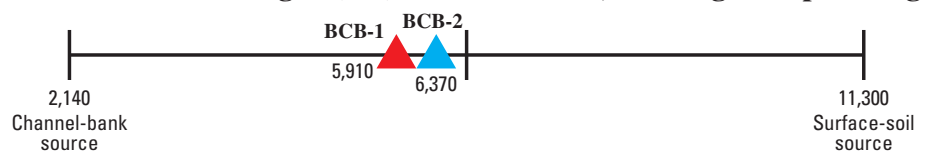

B. Clay-normalized total phosphorus (TP) concentrations, in milligrams per kilogram

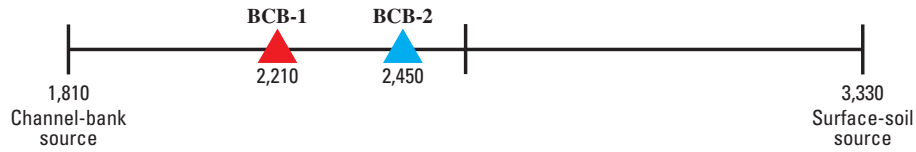

C. Clay-normalized total organic carbon (TOC) concentrations, in percent

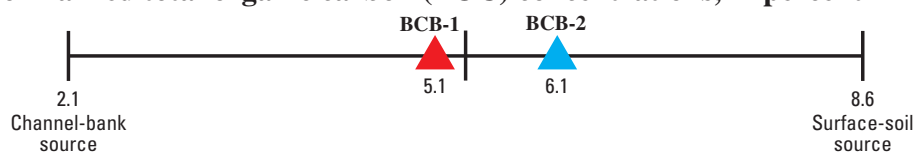

D. Clay-normalized cesium-137 activity, in picocuries per gram

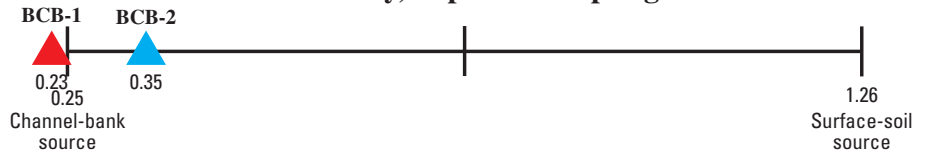

E. Ratio of TOC:TN

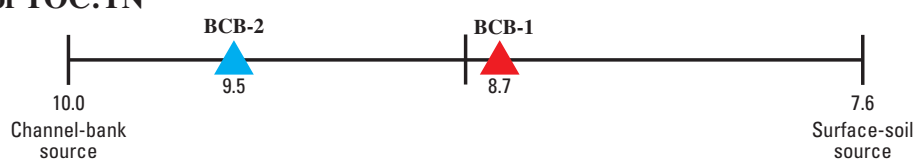

F. Ratio of TOC:TP

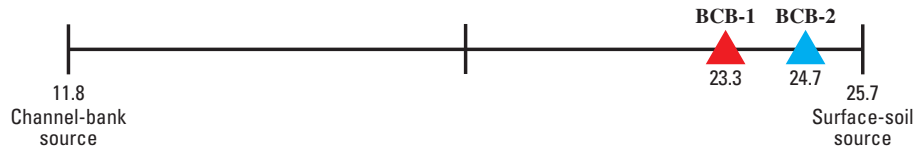

G. Ratio of TN:TP

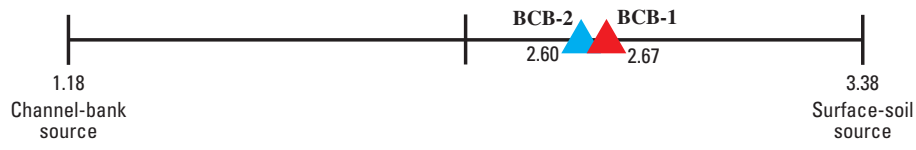

EXPLANATION

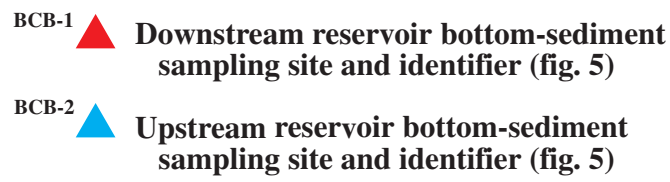

Note: Values indicate constituent concentration, activity, or ratio.
Figure 12. Comparison of channel-bank, surfacesoil, and reservoir bottom-sediment composition using clay-normalized total nitrogen, total phosphorus, and total organic carbon concentrations, clay-normalized cesium-137 activity, and ratios of total organic carbon to total nitrogen, total organic carbon to total phosphorus, and total nitrogen to total phosphorus for Banner Creek Reservoir, April and May 2005. Location of Banner Creek Reservoir shown in figure 2 . effectiveness of measures implemented to decrease erosion and in-stream sediment loads may improve if such locational differences are taken into account. For example, in the Atchison County Lake subbasin, the sediment-source estimation indicated that priority be given to surface-soil erosion. However, any sediment management strategy needs to be carefully conceived to avoid such unintentional consequences as problem transference. Case in point, channel erosion typically increases when in-stream sediment loads are small. Thus, effective erosion control on cropland may result in increased channel erosion if the runoff also is not controlled (National Research Council, 1993).

\section{Lake Wabaunsee}

For Lake Wabaunsee, the seven sediment-source indicators indicated that both channel-bank and surface-soil sources contributed substantial sediment (fig. 14, table 6). Thus, Lake Wabaunsee was similar to Banner Creek Reservoir in that both had a grassland-dominated basin from which both sources 
A. Clay-normalized total nitrogen (TN) concentrations, in milligrams per kilogram

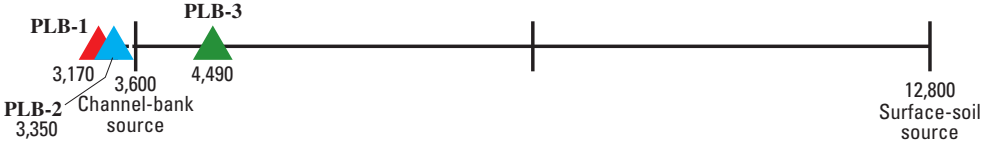

$B$. Clay-normalized total phosphorus (TP) concentrations, in milligrams per kilogram

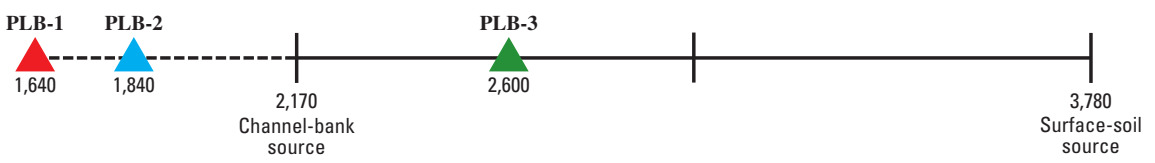

C. Clay-normalized total organic carbon (TOC) concentrations, in percent

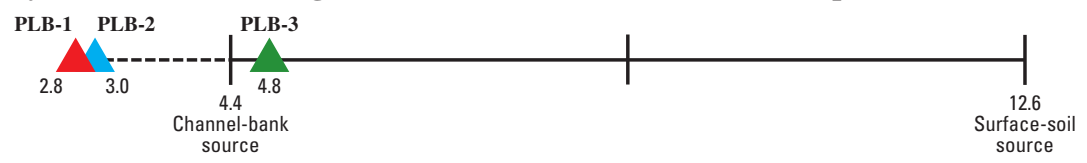

D. Clay-normalized cesium-137 activity, in picocuries per gram

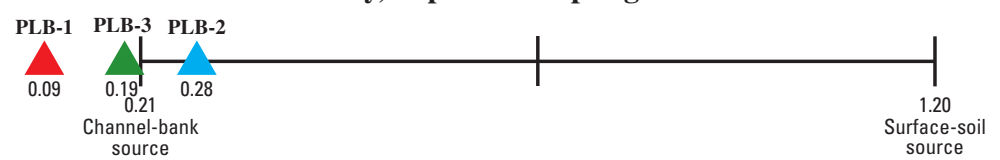

E. Ratio of TOC:TN

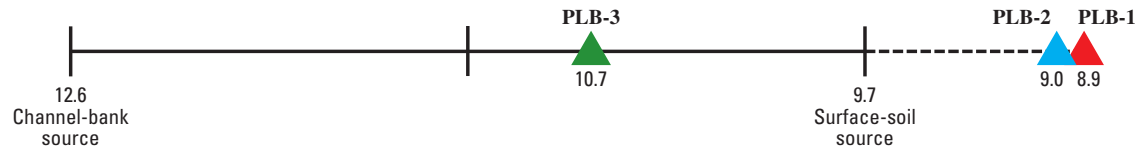

F. Ratio of TOC:TP

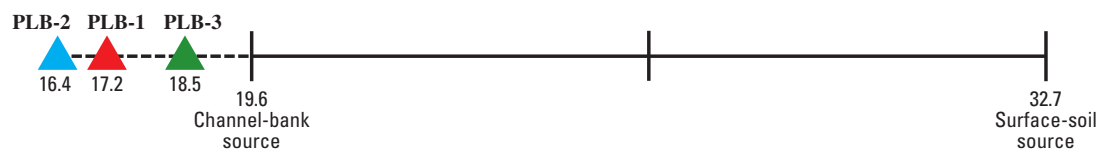

G. Ratio of TN:TP

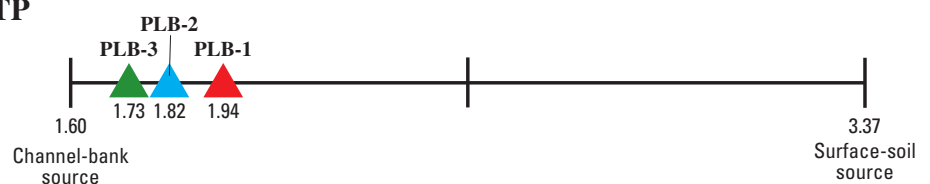

\section{EXPLANATION}

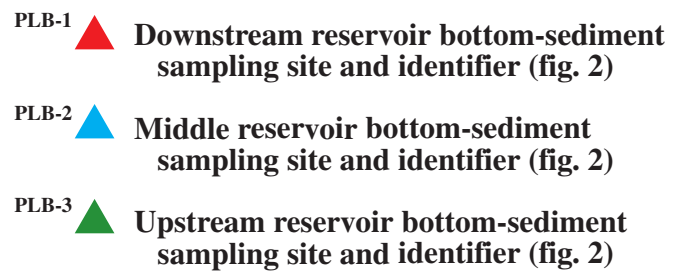

Note: Values indicate constituent concentration, activity, or ratio.

Figure 13. Comparison of channel-bank, surface-soil, and reservoir bottom-sediment composition using claynormalized total nitrogen, total phosphorus, and total organic carbon concentrations, clay-normalized cesium-137 activity, and ratios of total organic carbon to total nitrogen, total organic carbon to total phosphorus, and total nitrogen to total phosphorus for Perry Lake, March-May 2005. Location of Perry Lake shown in figures 1 and 2. 
A. Clay-normalized total nitrogen (TN) concentrations, in milligrams per kilogram

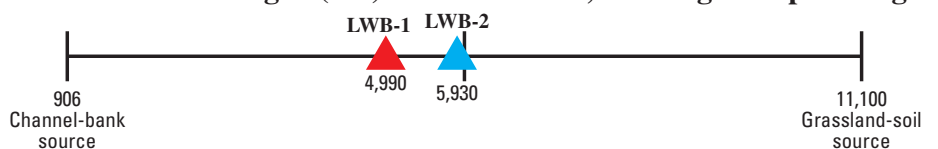

B. Clay-normalized total phosphorus (TP) concentrations, in milligrams per kilogram

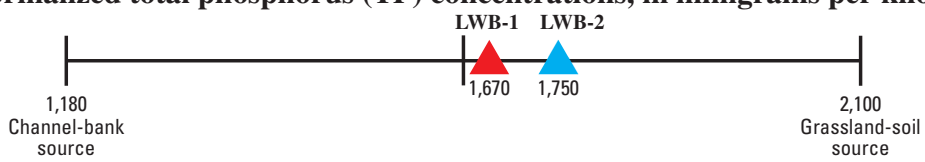

C. Clay-normalized total organic carbon (TOC) concentrations, in percent

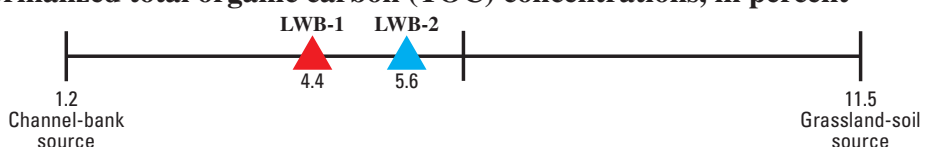

D. Clay-normalized cesium-137 activity, in picocuries per gram

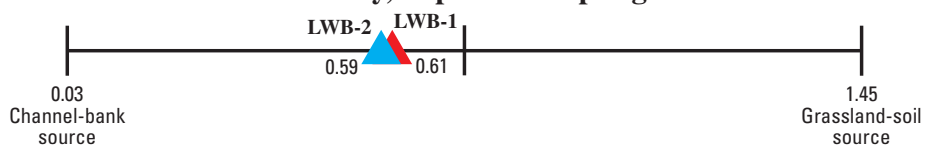

E. Ratio of TOC:TN

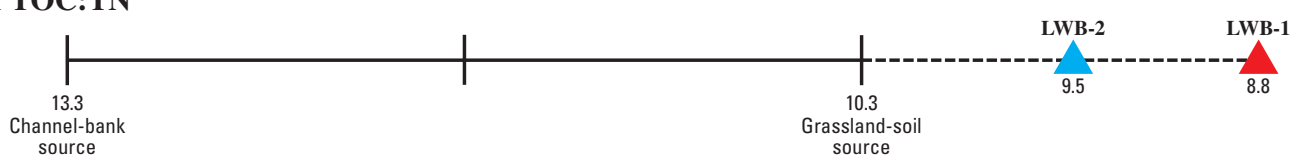

F. Ratio of TOC:TP

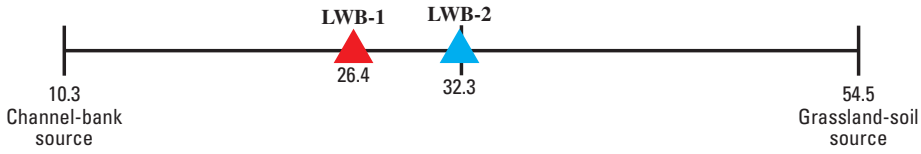

G. Ratio of TN:TP

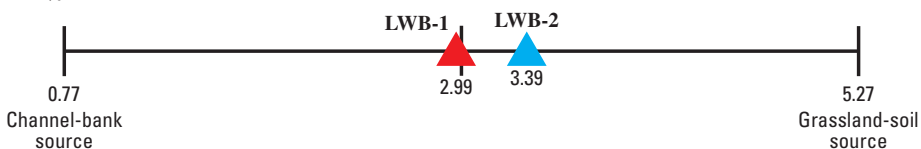

\section{EXPLANATION}

LWB-1

Downstream reservoir bottom-sediment sampling site and identifier (fig. 3)

LWB-2 Upstream reservoir bottom-sediment sampling site and identifier (fig. 3)

Note: Values indicate constituent concentration, activity, or ratio.

Figure 14. Comparison of channel-bank, surface-soil, and reservoir bottom-sediment composition using clay-normalized total nitrogen, total phosphorus, and total organic carbon concentrations, clay-normalized cesium-137 activity, and ratios of total organic carbon to total nitrogen, total organic carbon to total phosphorus, and total nitrogen to total phosphorus for Lake Wabaunsee, May 2005. Location of Lake Wabaunsee shown in figures 1 and 3. 
contributed substantially to the sediment deposited in the reservoir.

It was anticipated that channel-bank sources might provide most of the sediment for Lake Wabaunsee and Banner Creek Reservoir as grassland has been shown to contribute very small amounts of sediment compared to cropland (Morris and Fan, 1998). However, if overgrazed, grassland areas can contribute a substantial amount of sediment (Pimentel and others, 1995; Collins and others, 1997c).

\section{Summary and Conclusions}

Stream and lake sediment is a primary concern in Kansas and nationally as related to several important issues including water quality and reservoir water-storage capacity. The ability to achieve meaningful decreases in sediment loads to reservoirs requires the determination of sediment sources within the contributing basins. A 2-year study by the U.S. Geological Survey, in cooperation with the Kansas Water Office and the Kansas Department of Health and Environment, was begun in 2004 to investigate sources of sediment within the Perry Lake and Lake Wabaunsee Basins of northeast Kansas. Specifically, the objective was to ascertain if the majority of the sediment deposited in the two reservoirs originated from the erosion of channel banks or surface soils within the contributing basins. The objective was accomplished by the collection, analysis, and comparison of representative samples of channel-bank sources, surface-soil sources (cropland and grassland), and reservoir bottom sediment. Prior to the chemical analyses, all samples were sieved to isolate the less than $63-\mu \mathrm{m}$ fraction (that is, the silt and clay) to partially account for differences in particle-size composition. The samples were analyzed for selected nutrients (total nitrogen and total phosphorus), organic and total carbon, 25 trace elements, and the radionuclide cesium-137 ( $\left.{ }^{137} \mathrm{Cs}\right)$.

On the basis of four selection criteria, total nitrogen (TN), total phosphorus (TP), total organic carbon (TOC), and ${ }^{137} \mathrm{Cs}$ were selected as the constituents that provided the best ability to discriminate between channel-bank and surface-soil sources in the Perry Lake and Lake Wabaunsee Basins. Of the four selected constituents, ${ }^{137} \mathrm{Cs}$ likely is the most reliable indicator of sediment source because it is known to be conservative in the environment. Trace elements were not selected because concentrations in the channel-bank and surface-soil sources generally were similar or did not vary in a consistent manner.

Following the chemical analyses, two additional approaches were used to further account for differences in particle-size composition between the sources and the reservoir bottom sediment prior to the sediment-source estimations. The first approach involved the use of ratios in which the ratio of TOC to TN, TOC to TP, and TN to TP were computed. The second approach involved a particle-size normalization in which the constituent concentrations (TN, TP, TOC) and ${ }^{137} \mathrm{Cs}$ activity were divided by percentage of clay. Thus, the sedi- ment-source estimations involved the use of seven sedimentsource indicators (that is, three constituent ratios and the claynormalized concentrations or activity for four constituents).

Within the Perry Lake Basin, the seven sediment-source indicators indicated that both channel-bank and surface-soil sources were important contributors of the sediment deposited in Atchison County Lake and Banner Creek Reservoir, whereas channel-bank sources were the dominant source of sediment for Mission Lake. On the sole basis of ${ }^{137} \mathrm{Cs}$, surfacesoil sources contributed the most sediment to Atchison County Lake, and channel-bank sources contributed the most sediment to Banner Creek Reservoir and Mission Lake. Six of the seven sediment-source indicators (including ${ }^{137} \mathrm{Cs}$ ) indicated that channel-bank sources were dominant for Perry Lake. These results indicate that channel-bank sources increased in importance with distance downstream in the Perry Lake Basin. For Lake Wabaunsee, the seven sediment-source indicators indicated that both channel-bank and surface-soil sources were important.

The information in this report represents a first attempt to determine the relative contribution of sediment from channel-bank and surface-soil sources within the Perry Lake and Lake Wabaunsee Basins. Potentially, this information may be used to help design effective sediment management strategies. Given that the relative contribution of sediment from channel-bank and surface-soil sources can vary within and between basins and over time, basin-specific strategies for sediment management and monitoring are appropriate. Because the results of this study provide a general indication of the relative importance of sediment sources and given that a small percentage of a basin can account for a large percentage of the sediment yield, additional research may be required to provide a more definitive understanding of sediment sources within a particular basin.

\section{References Cited}

American Society for Testing and Materials, 2004, Standard practice for high-resolution gamma-ray spectrometry of water, in Annual book of ASTM standards, section 11, water and environmental technology: West Conshohocken, Pennsylvania, ASTM, v. 11.02, D 3649-98a, p. 285-295.

Arbogast, B.F., 1996, Analytical methods manual for the Mineral Resource Surveys Program: U.S. Geological Survey Open-File Report 96-525, 248 p.

Briggs, P.H., and Meier, A.L., 1999, The determination of forty two elements in geological materials by inductively coupled plasma-mass spectrometry: U.S. Geological Survey Open-File Report 99-166, 15 p. 
Collins, A.L., and Walling, D.E., 2002, Selecting fingerprint properties for discriminating potential suspended sediment sources in river basins: Journal of Hydrology, v. 261, p. 218-244.

Collins, A.L., and Walling, D.E., 2004, Documenting catchment suspended sediment sources-problems, approaches and prospects: Progress in Physical Geography, v. 28, p. 159-196.

Collins, A.L., Walling, D.E., and Leeks, G.J.L., 1997a, Source type ascription for fluvial suspended sediment based on a quantitative composite fingerprinting technique: Catena, v. 29 , p. 1-27.

Collins, A.L., Walling, D.E., and Leeks, G.J.L., 1997b, Sediment sources in the Upper Severn catchment-a fingerprinting approach: Hydrology and Earth System Sciences, v. 1, p. 509-521.

Collins, A.L., Walling, D.E., and Leeks, G.J.L., 1997c, Fingerprinting the origin of fluvial suspended sediment in larger river basins - combining assessment of spatial provenance and source type: Geografiska Annaler, v. 79A, p. 239-254.

Collins, A.L., Walling, D.E., and Leeks, G.J.L., 1998, Use of composite fingerprints to determine the provenance of the contemporary suspended sediment load transported by rivers: Earth Surface Processes and Landforms, v. 23, p. 31-52.

Fenneman, N.M., 1946, Physical divisions of the United States: U.S. Geological Survey special map, scale 1:7,000,000, 1 sheet.

Fishman, M.J., and Friedman, L.C., eds., 1989, Methods for determination of inorganic substances in water and fluvial sediments: U.S. Geological Survey Techniques of WaterResources Investigations, book 5, chap. A1, 545 p.

Foster, I.D.L., and Walling, D.E., 1994, Using reservoir deposits to reconstruct changing sediment yields and sources in the catchment of the Old Mill Reservoir, South Devon, UK, over the past 50 years: Hydrological Sciences Journal, v. 39, p. 347-368.

Gruszowski, K.E., Foster, I.D.L., Lees, J.A., and Charlesworth, S.M., 2003, Sediment sources and transport pathways in a rural catchment, Herefordshire, UK: Hydrological Processes, v. 17, p. 2665-2681.

Guy, H.P., 1969, Laboratory theory and methods for sediment analysis: U.S. Geological Survey Techniques of WaterResources Investigations, book 5, chap. C1, 58 p.

He, Q., and Owens, P., 1995, Determination of suspended sediment provenance using caesium-137, unsupported lead210 and radium-226 - a numerical mixing model approach, chapter 12, in Foster, I., Gurnell, A., and Webb, B., eds., Sediment and water quality in river catchments: New York, John Wiley \& Sons, p. 207-227.
He, Q., and Walling, D.E., 1996, Interpreting particle size effects in the adsorption of ${ }^{137} \mathrm{Cs}$ and unsupported ${ }^{210} \mathrm{~Pb}$ by mineral soils and sediments: Journal of Environmental Radioactivity, v. 30, p. 117-137.

Helsel, D.R., and Hirsch, R.M., 1992, Statistical methods in water resources: Amsterdam, Elsevier Science Publ., 529 p.

High Plains Regional Climate Center, 2005, Historical data summaries: Information available on the Web, accessed November 30, 2005, at http://www.hprcc.unl.edu/

Horowitz, A.J., 1991, A primer on sediment-trace element chemistry ( $2^{\text {nd }}$ ed.): Chelsea, Michigan, Lewis Publ., 136 p.

Horowitz, A.J., Elrick, K.A., and Smith, J.J., 2001, Estimating suspended sediment and trace element fluxes in large river basins - methodological considerations as applied to the NASQAN program: Hydrological Processes, v. 15, p. 1107-1132.

Jobbagy, E.G., and Jackson, R.B., 2000, The vertical distribution of soil organic carbon and its relation to climate and vegetation: Ecological Applications, v. 10, p. 423-436.

Jordan, P.R., and Stamer, J.K., eds.,1995, Surface-water-quality assessment of the lower Kansas River Basin, Kansas and Nebraska_analysis of available data through 1986: U.S. Geological Survey Water-Supply Paper 2352-B, 161 p.

Juracek, K.E., 2000, Depth-weighted, mean soil permeability in Kansas: U.S. Geological Survey Open-File Report 00-252, available as digital spatial data from the Kansas Data Access and Support Center in Lawrence, Kansas, at http://gisdasc.kgs.ukans.edu/dasc_net.html.

Juracek, K.E., 2003, Sediment deposition and occurrence of selected nutrients, other chemical constituents, and diatoms in bottom sediment, Perry Lake, northeast Kansas, 19692001: U.S. Geological Survey Water-Resources Investigations Report 03-4025, 56 p.

Kansas Applied Remote Sensing Program, 1993, Kansas land cover data base, 1:100,000 scale: Lawrence, Kansas, Data Access and Support Center, available on CD.

Knighton, D., 1998, Fluvial forms and processes-a new perspective: New York, John Wiley and Sons, 383 p.

Lake Wabaunsee Sportsmen Association, 1971, Lake Wabaunsee Sportsmen Association history and directory: 59 p.

Lawler, D.M., Grove, J.R., Couperthwaite, J.S., and Leeks, G.J.L., 1999, Downstream change in river bank erosion rates in the Swale-Ouse system, northern England: Hydrological Processes, v. 13, p. 977-992.

Morris, G.L., and Fan, Jiahua, 1998, Reservoir sedimentation handbook: New York, McGraw-Hill, various pagination. 
Motha, J.A., Wallbrink, P.J., Hairsine, P.B., and Grayson, R.B., 2002, Tracer properties of eroded sediment and source material: Hydrological Processes, v. 16, p. 1983-2000.

Mudroch, Alena, and Azcue, J.M., 1995, Manual of aquatic sediment sampling: Boca Raton, Florida, Lewis Publishers, 219 p.

Nagle, G.N., and Ritchie, J.C., 1999, The use of tracers to study sediment sources in three streams in northeastern Oregon: Physical Geography, v. 20, p. 348-366.

National Research Council, 1993, Soil and water quality-an agenda for agriculture: Washington, D.C., National Academy Press, 516 p.

Peart, M.R., and Walling, D.E., 1986, Fingerprinting sediment source - the example of a drainage basin in Devon, UK, in Hadley, R.F., ed., Drainage basin sediment delivery: International Association of Hydrological Sciences Publication No. 159 , p. $41-55$.

Pimentel, David, Harvey, C., Resosudarmo, P., Sinclair, K., Kurz, D., McNair, M., Crist, S., Shpritz, L., Fitton, L., Saffouri, R., and Blair, R., 1995, Environmental and economic costs of soil erosion and conservation benefits: Science, v. 267 , p. $1117-1123$.

Ritchie, J.C., and McHenry, J.R., 1990, Application of radioactive fallout cesium- 137 for measuring soil erosion and sediment accumulation rates and patterns-a review: Journal of Environmental Quality, v. 19, p. 215-233.

Russell, M.A., Walling, D.E., and Hodgkinson, R.A., 2001, Suspended sediment sources in two small lowland agricultural catchments in the UK: Journal of Hydrology, v. 252, p. $1-24$.

Schoewe, W.H., 1949, The geography of Kansas: Transactions Kansas Academy of Science, v. 52, p. 261-333.

Smol, J.P., 2002, Pollution of lakes and rivers-a paleoenvironmental perspective: New York, Oxford University Press, $280 \mathrm{p}$.

U.S. Army Corps of Engineers, 1973, Lower Kansas River Basin lake regulation manual, volume 3, Perry Lake, Kansas: Kansas City, Missouri, U.S. Army Corps of Engineers, Kansas City District, July 1973, various pagination.

U.S. Department of Agriculture, 1994, State soil geographic data base-U.S. coverage by States including Puerto Rico: U.S. Department of Agriculture, Soil Conservation Service, October 1994, CD-ROM digital data.

U.S. Department of Agriculture, Soil Conservation Service, 1960, Soil survey of Brown County, Kansas: 32 p.
U.S. Department of Agriculture, Soil Conservation Service, 1977, Soil survey of Jefferson County, Kansas: 67 p.

U.S. Department of Agriculture, Soil Conservation Service, 1979, Soil survey of Jackson County, Kansas: 86 p.

U.S. Department of Agriculture, Soil Conservation Service, 1982, Soil survey of Nemaha County, Kansas: 89 p.

U.S. Department of Agriculture, Soil Conservation Service, 1984, Soil survey of Atchison County, Kansas: 105 p.

U.S. Department of Agriculture, Soil Conservation Service, 1991, Soil survey of Wabaunsee County, Kansas: 132 p.

U.S. Environmental Protection Agency, 1991, Guidance of water quality-based decisions - the TMDL process: Washington, D.C., Office of Water, EPA440/4-91-001, 59 p.

Walling, D.E., 1983, The sediment delivery problem: Journal of Hydrology, v. 65, p. 209-237.

Walling, D.E., 2005, Tracing suspended sediment sources in catchments and river systems: Science of the Total Environment, v. 344, p. 159-184.

Walling, D.E., and Kane, P., 1984, Suspended sediment properties and their geomorphological significance, chap. 19, in Burt, T.P., and Walling, D.E., eds., Catchment experiments in fluvial geomorphology: Norwich, England, Geo Books, p. 311-334.

Walling, D.E., Owens, P.N., and Leeks, G.J.L., 1999, Fingerprinting suspended sediment sources in the catchment of the River Ouse, Yorkshire, UK: Hydrological Processes, v. 13, p. 955-975.

Walling, D.E., and Woodward, J.C., 1992, Use of radiometric fingerprints to derive information on suspended sediment sources, in Bogen, J., Walling, D.E., and Day, T.J., eds., Erosion and sediment transport monitoring programmes in river basins: International Association of Hydrological Sciences Publication No. 210, p. 153-164.

Walling, D.E., and Woodward, J.C., 1995, Tracing sources of suspended sediment in river basins - a case study of the River Culm, Devon, UK: Marine and Freshwater Research, v. 46, p. $327-336$.

Wentworth, C.K., 1922, A scale of grade and class terms for clastic sediments: Journal of Geology, v. 30, p. 377-392.

Zhang, Xinbao, and Walling, D.E., 2005, Characterizing land surface erosion from cesium-137 profiles in lake and reservoir sediments: Journal of Environmental Quality, v. 34, p. 514-523. 


\section{Supplemental Information}


Table A1. Percentage of clay and original and clay-normalized constituent concentrations and cesium-137 activity for channel-bank, cropland-soil, grassland-soil, and reservoir bottom-sediment samples collected in the Atchison County Lake subbasin (fig. 4), northeast Kansas, April and May 2005.

[mg/kg, milligrams per kilogram; \%, percent; pCi/g, picocuries per gram; <, less than; --, not determined]

\begin{tabular}{|c|c|c|c|c|c|c|}
\hline \multirow{3}{*}{$\begin{array}{l}\text { Constituent and unit of } \\
\text { measurement }\end{array}$} & \multicolumn{6}{|c|}{ Source materials } \\
\hline & \multicolumn{2}{|c|}{ Channel banks' } & \multicolumn{2}{|c|}{ Cropland soils $^{2}$} & \multicolumn{2}{|c|}{ Grassland soils ${ }^{3}$} \\
\hline & Original & Normalized $^{4}$ & Original & Normalized $^{4}$ & Original & Normalized $^{4}$ \\
\hline \multicolumn{7}{|c|}{ Nutrients } \\
\hline Total nitrogen $(\mathrm{TN}), \mathrm{mg} / \mathrm{kg}$ & 400 & 1,850 & 1,400 & 7,040 & 2,300 & 12,500 \\
\hline Carbon (total organic, TOC), $\%$ & .6 & 2.8 & 1.4 & 7.0 & 2.6 & 14.1 \\
\hline Carbon (total), \% & .5 & 2.3 & 1.6 & 8.0 & 2.3 & 12.5 \\
\hline \multicolumn{7}{|c|}{ Trace elements } \\
\hline Aluminum, $\%$ & 5.0 & 23 & 5.1 & 26 & 5.0 & 27 \\
\hline Antimony, mg/kg & .8 & 3.7 & .7 & 3.5 & .8 & 4.3 \\
\hline Cadmium, mg/kg & $<.2$ & -- & .1 & .5 & .2 & 1.1 \\
\hline Chromium, mg/kg & 45 & 210 & 45 & 230 & 44 & 240 \\
\hline Cobalt, $\mathrm{mg} / \mathrm{kg}$ & 6 & 28 & 5 & 25 & 7 & 38 \\
\hline Copper, $\mathrm{mg} / \mathrm{kg}$ & 14 & 65 & 14 & 70 & 17 & 92 \\
\hline Iron, $\%$ & 1.9 & 8.8 & 1.9 & 9.5 & 1.9 & 10.3 \\
\hline Lead, mg/kg & 16 & 74 & 19 & 95 & 26 & 140 \\
\hline Lithium, $\mathrm{mg} / \mathrm{kg}$ & 21 & 97 & 22 & 110 & 21 & 110 \\
\hline Manganese, $\mathrm{mg} / \mathrm{kg}$ & 320 & 1,480 & 350 & 1,760 & 410 & 2,230 \\
\hline Thallium, mg/kg & $<100$ & -- & $<50$ & -- & $<100$ & -- \\
\hline Tin, mg/kg & 1.7 & 7.9 & 2.1 & 10.6 & 2.7 & 14.7 \\
\hline Titanium, $\%$ & .38 & 1.76 & .39 & 1.96 & .37 & 2.01 \\
\hline Uranium, mg/kg & $<100$ & -- & $<50$ & -- & $<100$ & -- \\
\hline Vanadium, mg/kg & 71 & 330 & 71 & 360 & 71 & 390 \\
\hline Zinc, mg/kg & 50 & 230 & 48 & 240 & 77 & 420 \\
\hline \multicolumn{7}{|c|}{ Radionuclide } \\
\hline Cesium-137, pCi/g & .05 & .23 & .13 & .65 & .18 & .98 \\
\hline
\end{tabular}


Table A1. Percentage of clay and original and clay-normalized constituent concentrations and cesium-137 activity for channel-bank, cropland-soil, grassland-soil, and reservoir bottom-sediment samples collected in the Atchison County Lake subbasin (fig. 4), northeast Kansas, April and May 2005.-Continued

[mg/kg, milligrams per kilogram; \%, percent; pCi/g, picocuries per gram; <, less than; --, not determined]

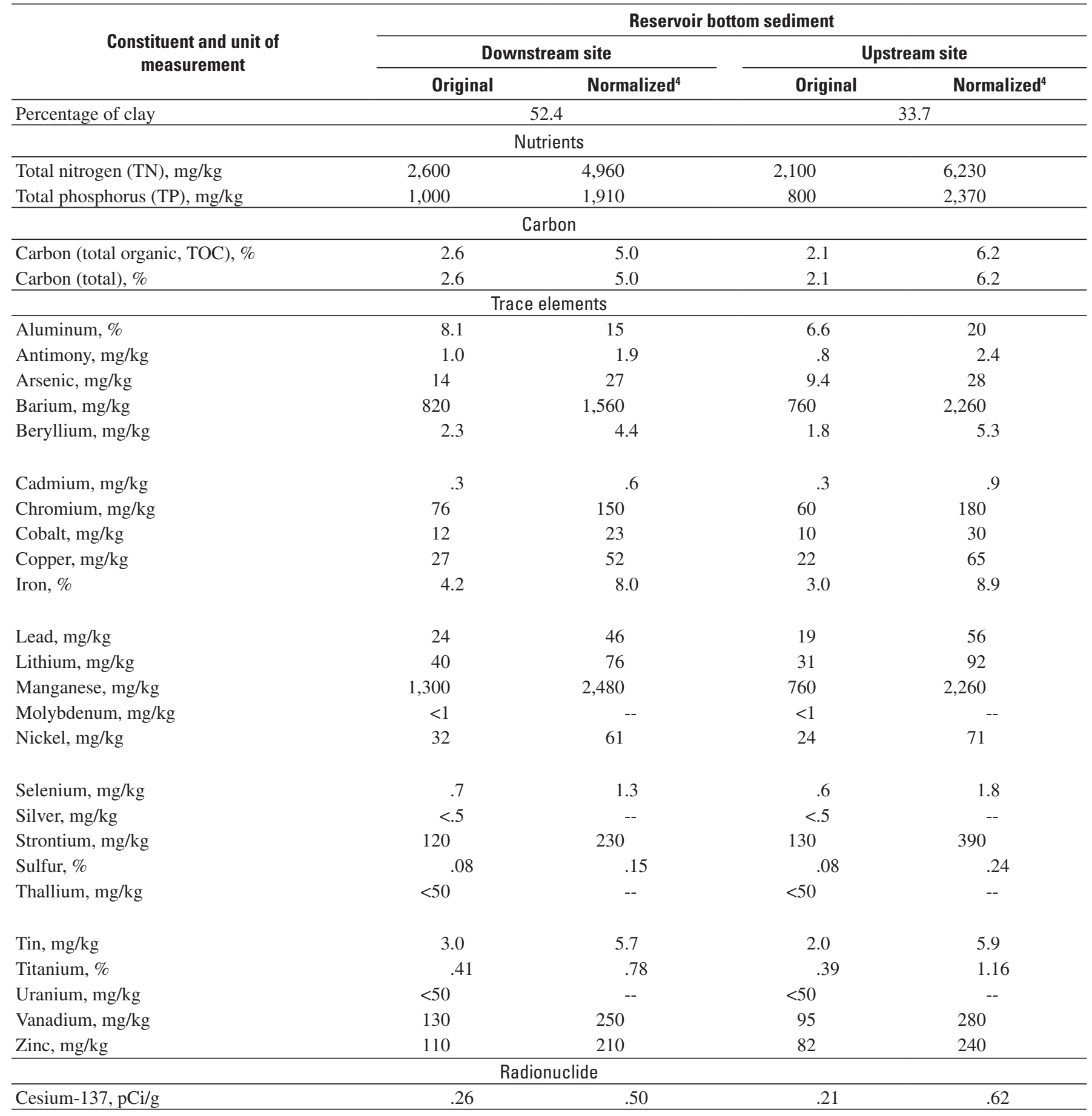

${ }^{1}$ Composite of four sites.

${ }^{2}$ Composite of five sites.

${ }^{3}$ Composite of three sites.

${ }^{4}$ Normalization achieved by dividing the original constituent concentration or cesium-137 activity by the percentage of clay. 
Table A2. Percentage of clay and original and clay-normalized constituent concentrations and cesium-137 activity for channel-bank, cropland-soil, grassland-soil, and reservoir bottom-sediment samples collected in the Banner Creek Reservoir subbasin (fig. 5), northeast Kansas, April and May 2005.

[mg/kg, milligrams per kilogram; \%, percent; pCi/g, picocuries per gram; <, less than; --, not determined]

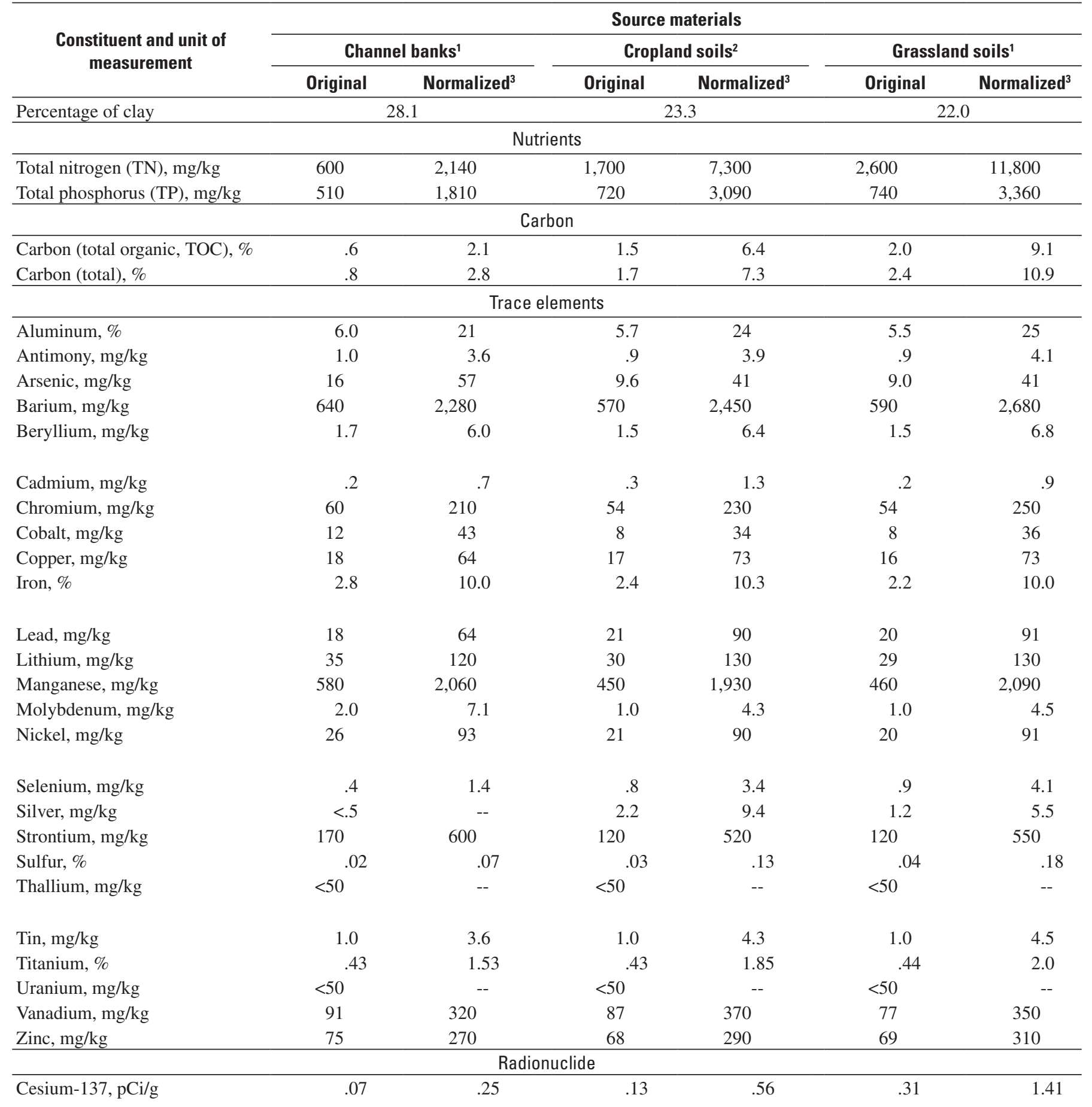


Table A2. Percentage of clay and original and clay-normalized constituent concentrations and cesium-137 activity for channel-bank, cropland-soil, grassland-soil, and reservoir bottom-sediment samples collected in the Banner Creek Reservoir subbasin (fig. 5), northeast Kansas, April and May 2005.-Continued

[mg/kg, milligrams per kilogram; \%, percent; pCi/g, picocuries per gram; <, less than; --, not determined]

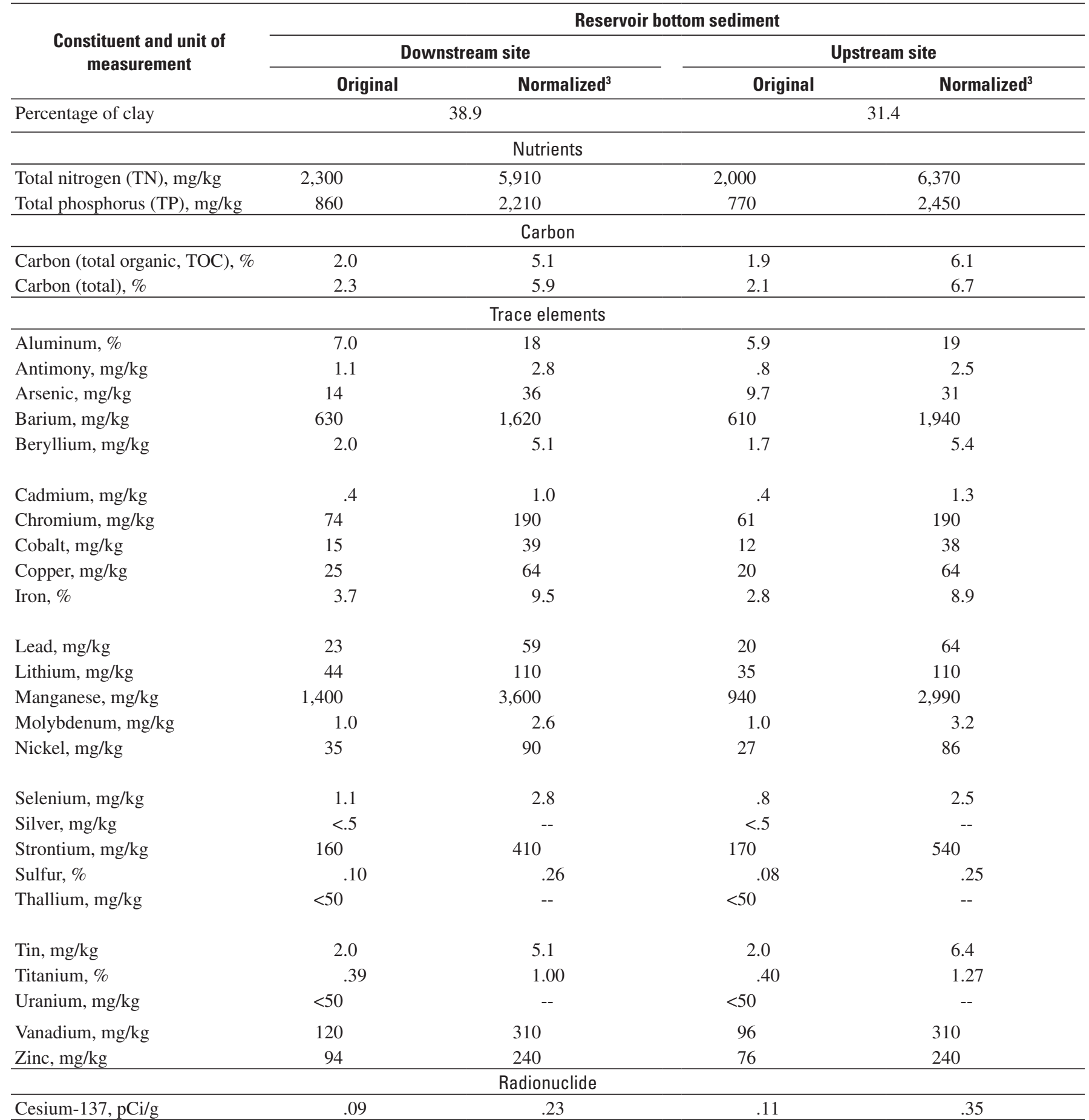

${ }^{1}$ Composite of five sites.

${ }^{2}$ Composite of three sites.

${ }^{3}$ Normalization achieved by dividing the original constituent concentration or cesium-137 activity by the percentage of clay. 
Table A3. Percentage of clay and original and clay-normalized constituent concentrations and cesium-137 activity for channel-bank, cropland-soil, and grassland-soil samples collected in the Gregg Creek subbasin (fig. 6), northeast Kansas, March and April 2005.

[mg/kg, milligrams per kilogram; \%, percent; pCi/g, picocuries per gram; <, less than; --, not determined]

\begin{tabular}{|c|c|c|c|c|c|c|}
\hline \multirow{3}{*}{$\begin{array}{l}\text { Constituent and unit of } \\
\text { measurement }\end{array}$} & \multicolumn{6}{|c|}{ Source materials } \\
\hline & \multicolumn{2}{|c|}{ Channel banks ${ }^{1}$} & \multicolumn{2}{|c|}{ Cropland soils ${ }^{1}$} & \multicolumn{2}{|c|}{ Grassland soils ${ }^{2}$} \\
\hline & Original & Normalized $^{3}$ & Original & Normalized $^{3}$ & Original & Normalized ${ }^{3}$ \\
\hline \multicolumn{7}{|c|}{ Nutrients } \\
\hline Total nitrogen $(\mathrm{TN}), \mathrm{mg} / \mathrm{kg}$ & 1,100 & 6,670 & 1,600 & 11,100 & 2,600 & 18,800 \\
\hline Carbon (total organic, TOC), $\%$ & 1.2 & 7.3 & 1.4 & 9.7 & 2.8 & 20.3 \\
\hline Carbon (total), $\%$ & 1.3 & 7.9 & 2.0 & 13.9 & 2.9 & 21.0 \\
\hline \multicolumn{7}{|c|}{ Trace elements } \\
\hline Aluminum, $\%$ & 5.3 & 32 & 5.2 & 36 & 5.3 & 38 \\
\hline Antimony, mg/kg & .8 & 4.8 & .7 & 4.9 & .8 & 5.8 \\
\hline Cadmium, mg/kg & .1 & 6 & .1 & .7 & .2 & 1.4 \\
\hline Chromium, mg/kg & 48 & 290 & 44 & 310 & 53 & 380 \\
\hline Cobalt, mg/kg & 7 & 42 & 6 & 42 & 7 & 51 \\
\hline Copper, mg/kg & 14 & 85 & 14 & 97 & 17 & 120 \\
\hline Iron, \% & 1.9 & 11.5 & 1.8 & 12.5 & 2.1 & 15.2 \\
\hline Lead, mg/kg & 16 & 97 & 17 & 120 & 19 & 140 \\
\hline Lithium, $\mathrm{mg} / \mathrm{kg}$ & 23 & 140 & 23 & 160 & 28 & 200 \\
\hline Manganese, $\mathrm{mg} / \mathrm{kg}$ & 410 & 2,480 & 410 & 2,850 & 370 & 2,680 \\
\hline Thallium, mg/kg & $<50$ & -- & $<50$ & -- & $<50$ & -- \\
\hline Tin, mg/kg & 1.0 & 6.1 & 1.0 & 6.9 & 2.0 & 14.5 \\
\hline Titanium, $\%$ & .40 & 2.42 & .39 & 2.71 & .36 & 2.61 \\
\hline Uranium, mg/kg & $<50$ & -- & $<50$ & -- & $<50$ & -- \\
\hline Vanadium, $\mathrm{mg} / \mathrm{kg}$ & 73 & 440 & 68 & 470 & 89 & 640 \\
\hline Zinc, $\mathrm{mg} / \mathrm{kg}$ & 56 & 340 & 58 & 400 & 68 & 490 \\
\hline \multicolumn{7}{|c|}{ Radionuclide } \\
\hline Cesium-137, pCi/g & .06 & .36 & .08 & .56 & .43 & 3.12 \\
\hline
\end{tabular}


Table A4. Percentage of clay and original and clay-normalized constituent concentrations and cesium-137 activity for channel-bank, cropland-soil, grassland-soil, and reservoir bottom-sediment samples collected in the Mission Lake subbasin (fig. 7), northeast Kansas, March-May 2005.

[mg/kg, milligrams per kilogram; \%, percent; pCi/g, picocuries per gram; <, less than; --, not determined]

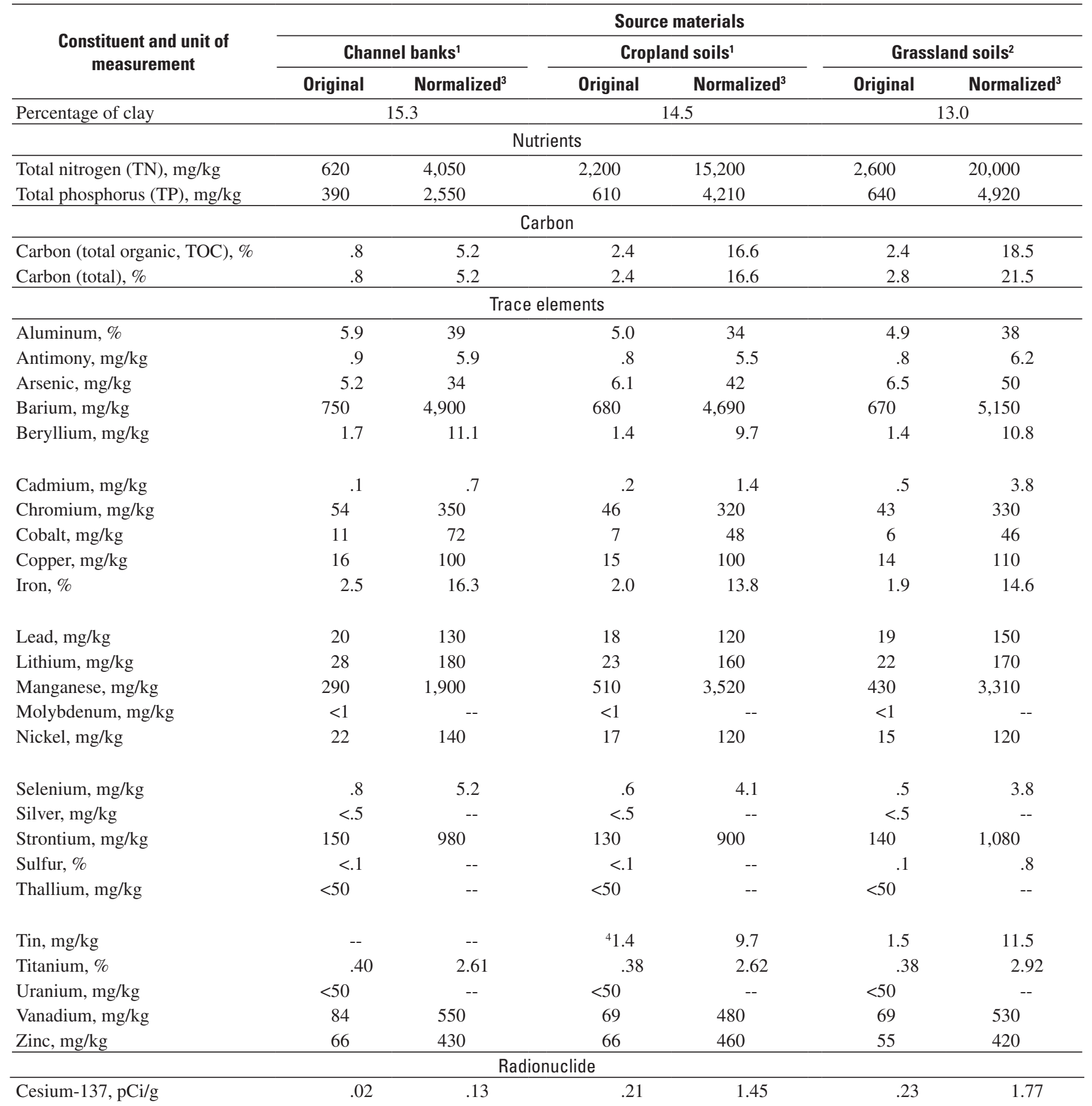


Table A4. Percentage of clay and original and clay-normalized constituent concentrations and cesium-137 activity for channel-bank, cropland-soil, grassland-soil, and reservoir bottom-sediment samples collected in the Mission Lake subbasin (fig. 7), northeast Kansas, March-May 2005.-Continued

[mg/kg, milligrams per kilogram; \%, percent; pCi/g, picocuries per gram; <, less than; --, not determined]

\begin{tabular}{|c|c|c|c|c|}
\hline \multirow{3}{*}{$\begin{array}{l}\text { Constituent and unit of } \\
\text { measurement }\end{array}$} & \multicolumn{4}{|c|}{ Reservoir bottom sediment } \\
\hline & \multicolumn{2}{|c|}{ Downstream site } & \multicolumn{2}{|c|}{ Upstream site } \\
\hline & Original & Normalized $^{3}$ & Original & Normalized $^{3}$ \\
\hline Percentage of clay & \multicolumn{2}{|c|}{47.4} & \multicolumn{2}{|c|}{37.2} \\
\hline \multicolumn{5}{|c|}{ Nutrients } \\
\hline Total nitrogen (TN), mg/kg & 2,600 & 5,490 & 1,800 & 4,840 \\
\hline Total phosphorus (TP), mg/kg & 1,100 & 2,320 & 670 & 1,800 \\
\hline \multicolumn{5}{|c|}{ Carbon } \\
\hline Carbon (total organic, TOC), $\%$ & 2.4 & 5.1 & 1.6 & 4.3 \\
\hline Carbon (total), \% & 2.5 & 5.3 & 1.8 & 4.8 \\
\hline \multicolumn{5}{|c|}{ Trace elements } \\
\hline Aluminum, $\%$ & 7.7 & 16 & 6.1 & 16 \\
\hline Antimony, mg/kg & 1.0 & 2.1 & .8 & 2.2 \\
\hline Arsenic, $\mathrm{mg} / \mathrm{kg}$ & 18 & 38 & 9.9 & 27 \\
\hline Barium, $\mathrm{mg} / \mathrm{kg}$ & 800 & 1,690 & 730 & 1,960 \\
\hline Beryllium, mg/kg & 2.2 & 4.6 & 1.7 & 4.6 \\
\hline Cadmium, mg/kg & .3 & .6 & .3 & .8 \\
\hline Chromium, mg/kg & 73 & 150 & 56 & 150 \\
\hline Cobalt, $\mathrm{mg} / \mathrm{kg}$ & 14 & 30 & 11 & 30 \\
\hline Copper, mg/kg & 28 & 59 & 20 & 54 \\
\hline Iron, $\%$ & 4.1 & 8.6 & 2.7 & 7.3 \\
\hline Lead, $\mathrm{mg} / \mathrm{kg}$ & 28 & 59 & 21 & 56 \\
\hline Lithium, mg/kg & 45 & 95 & 32 & 86 \\
\hline Manganese, $\mathrm{mg} / \mathrm{kg}$ & 1,800 & 3,800 & 850 & 2,280 \\
\hline Molybdenum, mg/kg & $<1$ & -- & $<1$ & -- \\
\hline Nickel, mg/kg & 34 & 72 & 24 & 65 \\
\hline Selenium, $\mathrm{mg} / \mathrm{kg}$ & .8 & 1.7 & .5 & 1.3 \\
\hline Silver, $\mathrm{mg} / \mathrm{kg}$ & $<.5$ & -- & $<.5$ & -- \\
\hline Strontium, $\mathrm{mg} / \mathrm{kg}$ & 120 & 250 & 130 & 350 \\
\hline Sulfur, \% & $<1.0$ & -- & $<1.0$ & -- \\
\hline Thallium, $\mathrm{mg} / \mathrm{kg}$ & $<50$ & -- & $<50$ & -- \\
\hline Tin, mg/kg & 3.0 & 6.3 & $<1.0$ & -- \\
\hline Titanium, \% & .42 & .89 & .39 & 1.05 \\
\hline Uranium, mg/kg & $<50$ & -- & $<50$ & -- \\
\hline Vanadium, mg/kg & 120 & 250 & 88 & 240 \\
\hline Zinc, mg/kg & 110 & 230 & 78 & 210 \\
\hline \multicolumn{5}{|c|}{ Radionuclide } \\
\hline Cesium-137, pCi/g & .22 & .46 & .13 & .35 \\
\hline
\end{tabular}

${ }^{1}$ Average concentration or percentage for five sites. Concentrations and percentages for individual channel-bank and cropland sites are provided in tables A9 and A10, respectively.

${ }^{2}$ Average concentration or percentage for three sites. Concentrations and percentages for individual grassland sites are provided in table A11.

${ }^{3}$ Normalization achieved by dividing the original constituent concentration or cesium-137 activity by the percentage of clay.

${ }^{4}$ Estimated as average concentration for four sites, one of which had a concentration of less than $1.0 \mathrm{mg} / \mathrm{kg}$. To compute the average, the belowdetection site was assigned a value of $0.5 \mathrm{mg} / \mathrm{kg}$. 
Table A5. Percentage of clay and original and clay-normalized constituent concentrations and cesium-137 activity for channel-bank, cropland-soil, and grassland-soil samples collected in the Walnut Creek subbasin (fig. 8), northeast Kansas, April and May 2005.

[mg/kg, milligrams per kilogram; \%, percent; pCi/g, picocuries per gram; <, less than; --, not determined]

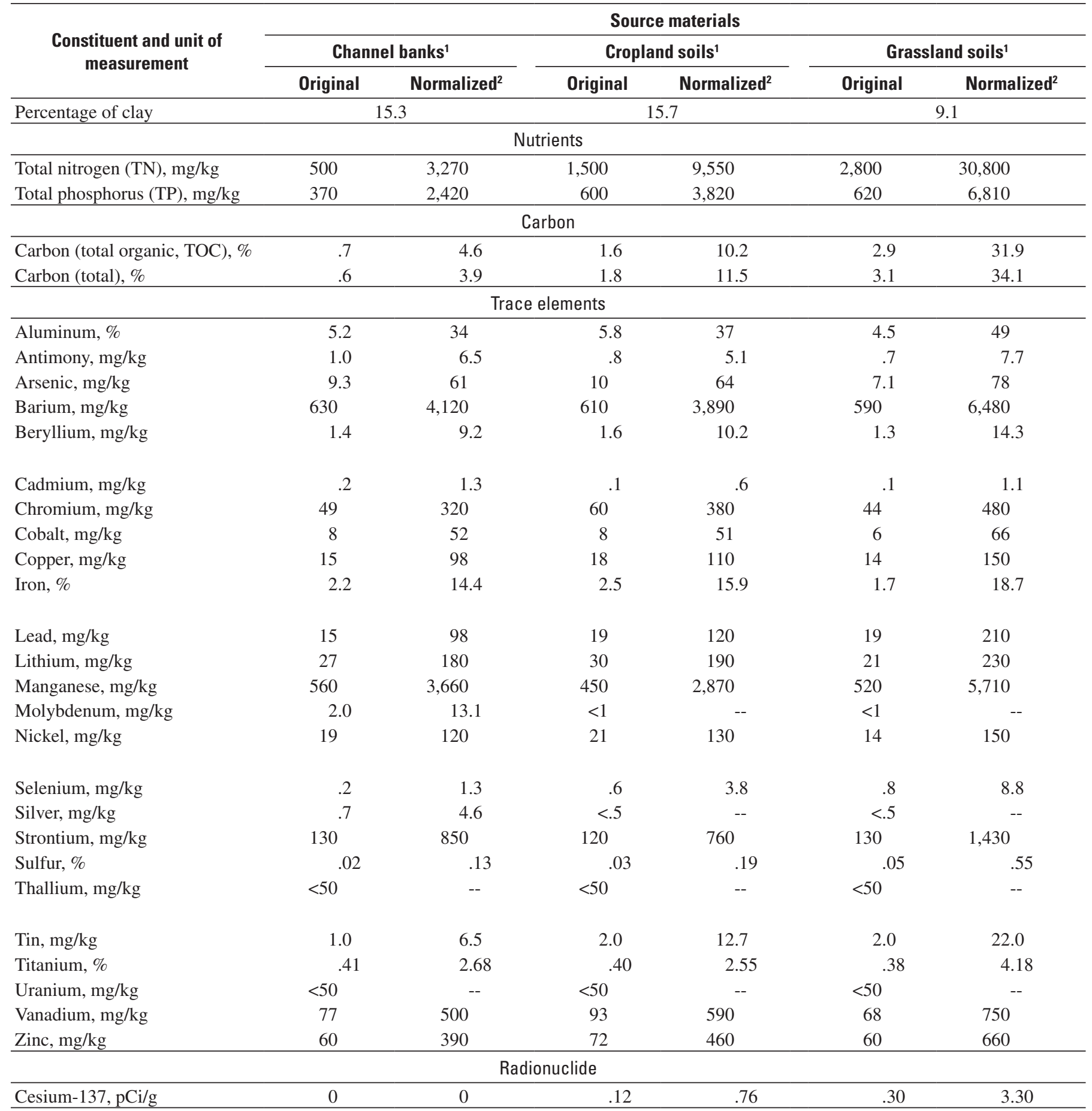

${ }^{1}$ Composite of five sites.

${ }^{2}$ Normalization achieved by dividing the original constituent concentration or cesium-137 activity by the percentage of clay. 
Table A6. Percentage of clay and original and clay-normalized constituent concentrations and cesium-137 activity for bottom-sediment samples collected from Perry Lake, northeast Kansas, May 2005.

[mg/kg, milligrams per kilogram; \%, percent; pCi/g, picocuries per gram; <, less than; --, not determined]

\begin{tabular}{|c|c|c|c|c|c|c|}
\hline \multirow{3}{*}{$\begin{array}{l}\text { Constituent and unit of } \\
\text { measurement }\end{array}$} & \multicolumn{6}{|c|}{ Bottom-sediment sampling sites (fig. 2) } \\
\hline & \multicolumn{2}{|c|}{ PLB-1 } & \multicolumn{2}{|c|}{ PLB-2 } & \multicolumn{2}{|c|}{ PLB-3 } \\
\hline & Original & Normalized $^{1}$ & Original & Normalized ${ }^{1}$ & Original & Normalized $^{1}$ \\
\hline Percentage of clay & \multicolumn{2}{|c|}{56.8} & \multicolumn{2}{|c|}{59.7} & \multicolumn{2}{|c|}{31.2} \\
\hline \multicolumn{7}{|c|}{ Nutrients } \\
\hline Total nitrogen $(\mathrm{TN}), \mathrm{mg} / \mathrm{kg}$ & 1,800 & 3,170 & 2,000 & 3,350 & 1,400 & 4,490 \\
\hline Total phosphorus (TP), mg/kg & 930 & 1,640 & 1,100 & 1,840 & 810 & 2,600 \\
\hline \multicolumn{7}{|c|}{ Carbon } \\
\hline Carbon (total organic, TOC), $\%$ & 1.6 & 2.8 & 1.8 & 3.0 & 1.5 & 4.8 \\
\hline Carbon (total), \% & 1.9 & 3.3 & 2.1 & 3.5 & 1.8 & 5.8 \\
\hline \multicolumn{7}{|c|}{ Trace elements } \\
\hline Aluminum, $\%$ & 8.4 & 15 & 9.5 & 16 & 7.2 & 23 \\
\hline Antimony, mg/kg & 1.3 & 2.3 & 1.1 & 1.8 & 1.1 & 3.5 \\
\hline Arsenic, mg/kg & 16 & 28 & 18 & 30 & 12 & 38 \\
\hline Barium, mg/kg & 680 & 1,200 & 730 & 1,220 & 740 & 2,370 \\
\hline Beryllium, mg/kg & 2.5 & 4.4 & 2.6 & 4.4 & 2.0 & 6.4 \\
\hline Cadmium, mg/kg & .6 & 1.1 & .6 & 1.0 & .6 & 1.9 \\
\hline Chromium, mg/kg & 80 & 140 & 87 & 150 & 67 & 210 \\
\hline Cobalt, mg/kg & 15 & 26 & 16 & 27 & 15 & 48 \\
\hline Copper, mg/kg & 29 & 51 & 31 & 52 & 25 & 80 \\
\hline Iron, $\%$ & 4.6 & 8.1 & 5.2 & 8.7 & 3.5 & 11.2 \\
\hline Lead, mg/kg & 28 & 49 & 28 & 47 & 24 & 77 \\
\hline Lithium, mg/kg & 54 & 95 & 60 & 100 & 41 & 130 \\
\hline Manganese, $\mathrm{mg} / \mathrm{kg}$ & 1,900 & 3,350 & 2,100 & 3,520 & 1,100 & 3,530 \\
\hline Molybdenum, mg/kg & 1.0 & 1.8 & 1.0 & 1.7 & 1.0 & 3.2 \\
\hline Nickel, mg/kg & 41 & 72 & 43 & 72 & 33 & 110 \\
\hline Selenium, mg/kg & 1.2 & 2.1 & 1.0 & 1.7 & .8 & 2.6 \\
\hline Silver, $\mathrm{mg} / \mathrm{kg}$ & $<.5$ & -- & $<.5$ & -- & $<.5$ & -- \\
\hline Strontium, mg/kg & 150 & 260 & 150 & 250 & 160 & 510 \\
\hline Sulfur, \% & .1 & .2 & .1 & .2 & .1 & .3 \\
\hline Thallium, mg/kg & $<50$ & -- & $<50$ & -- & $<50$ & -- \\
\hline Tin, mg/kg & 2.7 & 4.8 & 2.6 & 4.4 & 2.1 & 6.7 \\
\hline Titanium, \% & .41 & .72 & .41 & .69 & .40 & 1.3 \\
\hline Uranium, mg/kg & $<50$ & -- & $<50$ & -- & $<50$ & -- \\
\hline Vanadium, mg/kg & 140 & 250 & 150 & 250 & 120 & 380 \\
\hline Zinc, mg/kg & 120 & 210 & 120 & 200 & 92 & 290 \\
\hline \multicolumn{7}{|c|}{ Radionuclide } \\
\hline Cesium-137, pCi/g & .05 & .09 & & 28 & .06 & 19 \\
\hline
\end{tabular}

${ }^{1}$ Normalization achieved by dividing the original constituent concentration or cesium-137 activity by the percentage of clay. 
Table A7. Percentage of clay and original and clay-normalized constituent concentrations and cesium-137 activity for channel-bank, grassland-soil, and reservoir bottom-sediment samples collected in the Lake Wabaunsee Basin (fig. 3), northeast Kansas, May 2005.

[mg/kg, milligrams per kilogram; \%, percent; pCi/g, picocuries per gram; <, less than; --, not determined]

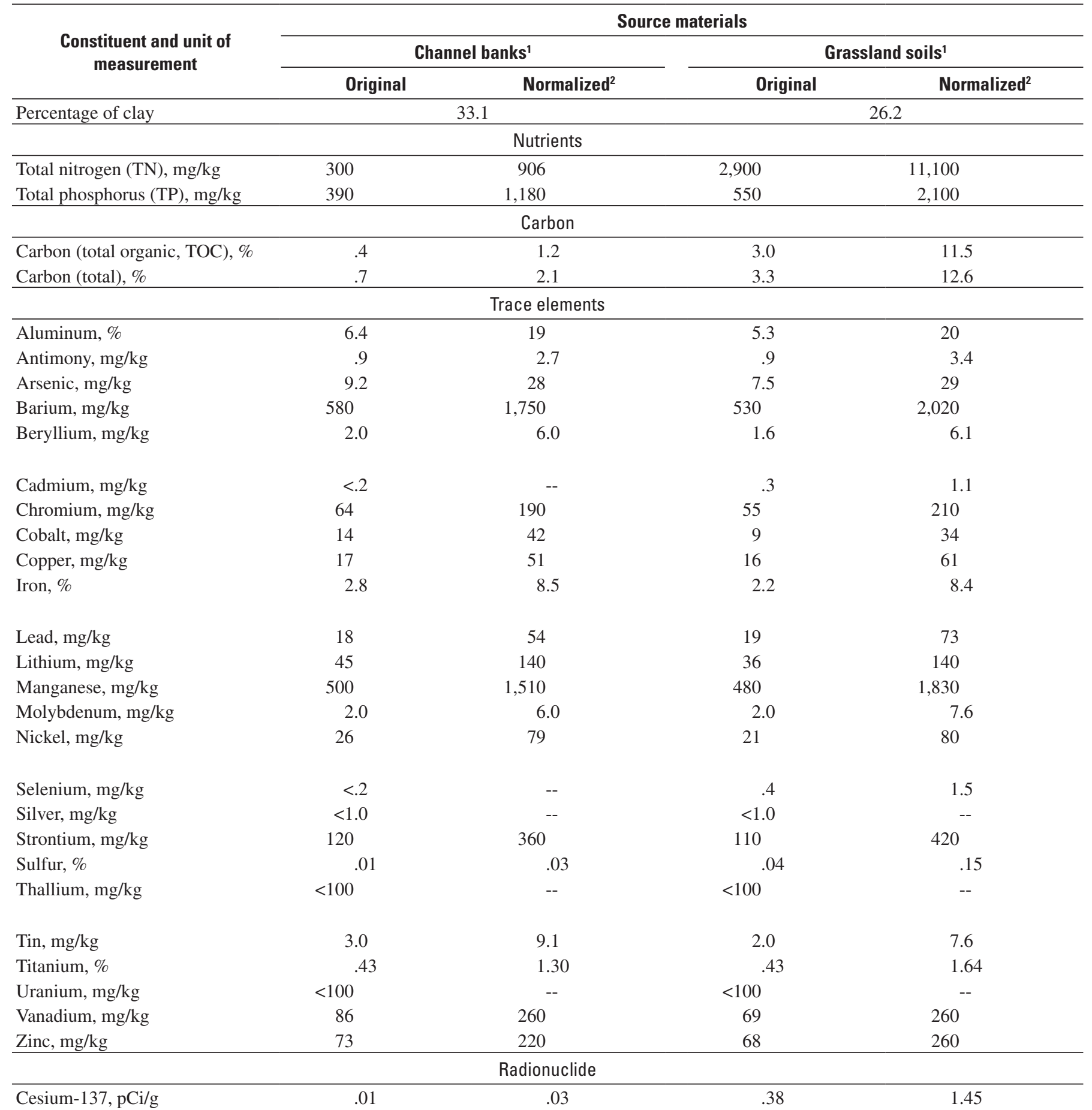


Table A7. Percentage of clay and original and clay-normalized constituent concentrations and cesium-137 activity for channel-bank, grassland-soil, and reservoir bottom-sediment samples collected in the Lake Wabaunsee Basin (fig. 3), northeast Kansas, May 2005.—Continued

[mg/kg, milligrams per kilogram; \%, percent; pCi/g, picocuries per gram; <, less than; --, not determined]

\begin{tabular}{|c|c|c|c|c|}
\hline \multirow{3}{*}{$\begin{array}{l}\text { Constituent and unit of } \\
\text { measurement }\end{array}$} & \multicolumn{4}{|c|}{ Reservoir bottom sediment } \\
\hline & \multicolumn{2}{|c|}{ Downstream site } & \multicolumn{2}{|c|}{ Upstream site } \\
\hline & Original & Normalized $^{2}$ & Original & Normalized $^{2}$ \\
\hline \multicolumn{5}{|c|}{ Nutrients } \\
\hline Total nitrogen $(\mathrm{TN}), \mathrm{mg} / \mathrm{kg}$ & 2,600 & 4,990 & 2,100 & 5,930 \\
\hline \multicolumn{5}{|c|}{ Carbon } \\
\hline Carbon (total organic, TOC), $\%$ & 2.3 & 4.4 & 2.0 & 5.6 \\
\hline Carbon (total), $\%$ & 3.6 & 6.9 & 3.4 & 9.6 \\
\hline \multicolumn{5}{|c|}{ Trace elements } \\
\hline Aluminum, $\%$ & 7.2 & 14 & 6.3 & 18 \\
\hline Beryllium, mg/kg & 2.2 & 4.2 & 1.9 & 5.4 \\
\hline Cadmium, mg/kg & .3 & .6 & .3 & .8 \\
\hline Chromium, mg/kg & 74 & 140 & 63 & 180 \\
\hline Cobalt, $\mathrm{mg} / \mathrm{kg}$ & 14 & 27 & 12 & 34 \\
\hline Copper, $\mathrm{mg} / \mathrm{kg}$ & 23 & 44 & 20 & 56 \\
\hline Iron, $\%$ & 3.9 & 7.5 & 3.1 & 8.8 \\
\hline Lead, $\mathrm{mg} / \mathrm{kg}$ & 21 & 40 & 19 & 54 \\
\hline Lithium, mg/kg & 59 & 110 & 49 & 140 \\
\hline Strontium, $\mathrm{mg} / \mathrm{kg}$ & 160 & 310 & 160 & 450 \\
\hline Sulfur, $\%$ & .09 & .17 & .08 & .23 \\
\hline Thallium, mg/kg & $<50$ & -- & $<50$ & -- \\
\hline Tin, mg/kg & 2.0 & 3.8 & 2.0 & 5.6 \\
\hline Titanium, $\%$ & .35 & .67 & .36 & 1.02 \\
\hline Uranium, mg/kg & $<50$ & -- & $<50$ & -- \\
\hline Vanadium, $\mathrm{mg} / \mathrm{kg}$ & 96 & 180 & 81 & 230 \\
\hline Zinc, $\mathrm{mg} / \mathrm{kg}$ & 90 & 170 & 74 & 210 \\
\hline \multicolumn{5}{|c|}{ Radionuclide } \\
\hline Cesium-137, pCi/g & .32 & .61 & .21 & .59 \\
\hline
\end{tabular}

${ }^{1}$ Composite of four sites.

${ }^{2}$ Normalization achieved by dividing the original constituent concentration or cesium-137 activity by the percentage of clay. 
Table A8. Original total nitrogen, total phosphorus, and total organic carbon concentrations and cesium-137 activity for channel-bank, croplandsoil, grassland-soil, surface-soil, and reservoir bottom-sediment samples collected in the Perry Lake and Lake Wabaunsee Basins, northeast Kansas, March-May 2005.

[mg/kg, milligrams per kilogram; \%, percent; pCi/g, picocuries per gram; --, not available]

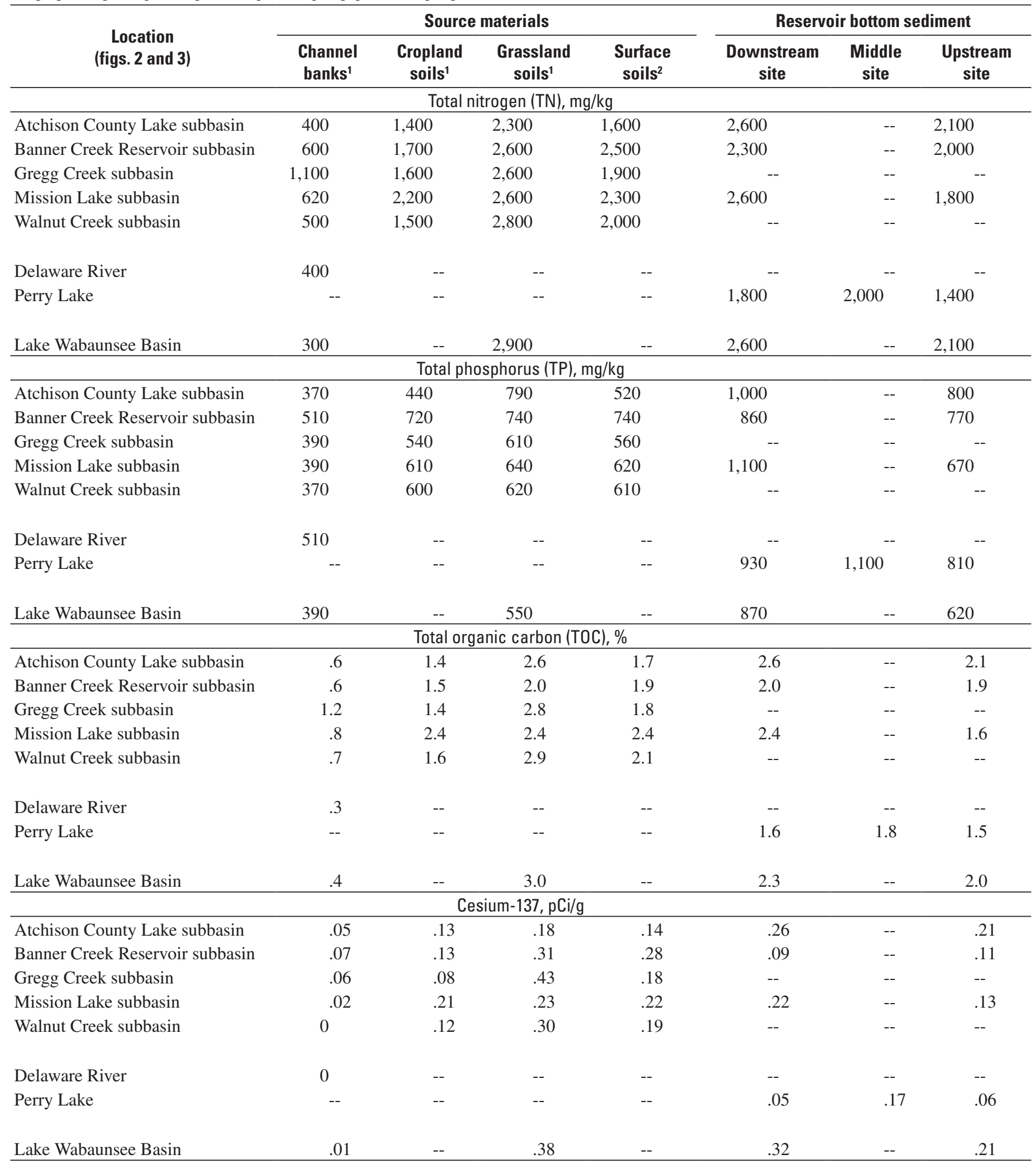

\footnotetext{
${ }^{1}$ Composite of three to five sites. See table 2.
}

${ }^{2}$ Surface-soil constituent concentrations and activities computed as the weighted average of the cropland-soil and grassland-soil constituent concentrations and activities for each subbasin using land use as the weighting factor. Land-use information for the subbasins is provided in table 1. 
Table A9. Percentage of clay and original constituent concentrations and cesium-137 activity for channel-bank samples collected at individual sites in the Mission Lake subbasin, northeast Kansas, March and April 2005.

[mg/kg, milligrams per kilogram; \%, percent; pCi/g, picocuries per gram; <, less than; --, not determined]

\begin{tabular}{|c|c|c|c|c|c|}
\hline \multirow{2}{*}{$\begin{array}{c}\text { Constituent and unit of } \\
\text { measurement }\end{array}$} & \multicolumn{5}{|c|}{ Channel-bank sampling sites (fig. 7) } \\
\hline & MB-1 & MB-2 & MB-3 & MB-4 & MB-5 \\
\hline Percentage of clay & 13.7 & 17.7 & 17.3 & 13.8 & 14.1 \\
\hline \multicolumn{6}{|c|}{ Nutrients } \\
\hline Total nitrogen $(\mathrm{TN}), \mathrm{mg} / \mathrm{kg}$ & 890 & 260 & 530 & 1,000 & 370 \\
\hline Total phosphorus (TP), mg/kg & 360 & 400 & 400 & 410 & 370 \\
\hline \multicolumn{6}{|c|}{ Carbon } \\
\hline Carbon (total organic, TOC), $\%$ & 1.1 & .3 & .5 & 1.3 & .6 \\
\hline Carbon (total), $\%$ & 1.1 & .3 & .5 & 1.3 & .6 \\
\hline \multicolumn{6}{|c|}{ Trace elements } \\
\hline Aluminum, $\%$ & 5.5 & 6.2 & 6.1 & 5.7 & 6.1 \\
\hline Antimony, mg/kg & .8 & .9 & 1.2 & .9 & .9 \\
\hline Arsenic, mg/kg & 6.0 & 3.7 & 4.2 & 6.7 & 5.5 \\
\hline Barium, mg/kg & 710 & 680 & 920 & 710 & 720 \\
\hline Beryllium, mg/kg & 1.5 & 1.8 & 1.8 & 1.6 & 1.7 \\
\hline Cadmium, mg/kg & .1 & $<.1$ & .3 & .1 & .08 \\
\hline Chromium, mg/kg & 49 & 56 & 55 & 52 & 56 \\
\hline Cobalt, $\mathrm{mg} / \mathrm{kg}$ & 6.0 & 4.7 & 29 & 7.6 & 9.3 \\
\hline Copper, mg/kg & 14 & 16 & 18 & 16 & 18 \\
\hline Iron, $\%$ & 2.1 & 2.7 & 3.0 & 2.3 & 2.6 \\
\hline Lead, $\mathrm{mg} / \mathrm{kg}$ & 16 & 16 & 31 & 18 & 18 \\
\hline Lithium, mg/kg & 25 & 29 & 31 & 29 & 28 \\
\hline Manganese, $\mathrm{mg} / \mathrm{kg}$ & 330 & 140 & 340 & 410 & 210 \\
\hline Molybdenum, mg/kg & $<1$ & $<1$ & $<1$ & $<1$ & $<1$ \\
\hline Nickel, mg/kg & 18 & 18 & 31 & 20 & 21 \\
\hline Selenium, $\mathrm{mg} / \mathrm{kg}$ & .4 & .1 & 2.9 & .5 & .2 \\
\hline Silver, $\mathrm{mg} / \mathrm{kg}$ & $<.5$ & $<.5$ & $<.5$ & $<.5$ & $<.5$ \\
\hline Strontium, mg/kg & 140 & 150 & 140 & 150 & 150 \\
\hline Sulfur, $\%$ & $<.1$ & $<.1$ & $<.1$ & $<.1$ & $<.1$ \\
\hline Thallium, mg/kg & $<50$ & $<50$ & $<50$ & $<50$ & $<50$ \\
\hline Tin, $\mathrm{mg} / \mathrm{kg}$ & -- & -- & -- & -- & -- \\
\hline Titanium, $\%$ & .39 & .40 & .39 & .41 & .42 \\
\hline Uranium, mg/kg & $<50$ & $<50$ & $<50$ & $<50$ & $<50$ \\
\hline Vanadium, mg/kg & 74 & 82 & 100 & 79 & 86 \\
\hline Zinc, mg/kg & 59 & 68 & 68 & 63 & 71 \\
\hline \multicolumn{6}{|c|}{ Radionuclide } \\
\hline Cesium-137, pCi/g & .07 & .01 & .01 & 0 & .01 \\
\hline
\end{tabular}


Table A10. Percentage of clay and original constituent concentrations and cesium-137 activity for cropland-soil samples collected at individual sites in the Mission Lake subbasin, northeast Kansas, March and April 2005.

[mg/kg, milligrams per kilogram; \%, percent; pCi/g, picocuries per gram; <, less than; --, not determined]

\begin{tabular}{|c|c|c|c|c|c|}
\hline \multirow{2}{*}{$\begin{array}{l}\text { Constituent and unit of } \\
\text { measurement }\end{array}$} & \multicolumn{5}{|c|}{ Cropland sampling sites (fig. 7) } \\
\hline & MC-1 & MC-2 & MC-3 & MC-4 & MC-5 \\
\hline Percentage of clay & 15.8 & 11.6 & 18.0 & 13.4 & 13.8 \\
\hline \multicolumn{6}{|c|}{ Nutrients } \\
\hline Total nitrogen (TN), mg/kg & 1,400 & 3,800 & 1,700 & 2,400 & 1,900 \\
\hline Total phosphorus (TP), mg/kg & 570 & 620 & 490 & 820 & 530 \\
\hline \multicolumn{6}{|c|}{ Carbon } \\
\hline Carbon (total organic, TOC), $\%$ & 1.6 & 4.3 & 1.8 & 2.3 & 2.0 \\
\hline Carbon (total), $\%$ & 1.4 & 4.4 & 1.8 & 2.5 & 2.0 \\
\hline \multicolumn{6}{|c|}{ Trace elements } \\
\hline Aluminum, $\%$ & 5.1 & 4.6 & 5.7 & 4.6 & 5.2 \\
\hline Antimony, mg/kg & .8 & .7 & .9 & .6 & .8 \\
\hline Arsenic, mg/kg & 6.4 & 4.3 & 7.6 & 5.4 & 6.6 \\
\hline Barium, mg/kg & 660 & 710 & 680 & 690 & 680 \\
\hline Beryllium, mg/kg & 1.4 & 1.3 & 1.6 & 1.3 & 1.5 \\
\hline Cadmium, mg/kg & .2 & .3 & .2 & .2 & .2 \\
\hline Chromium, mg/kg & 46 & 42 & 53 & 39 & 50 \\
\hline Cobalt, $\mathrm{mg} / \mathrm{kg}$ & 7.0 & 8.0 & 9.0 & 5.9 & 7.0 \\
\hline Copper, mg/kg & 15 & 16 & 17 & 13 & 15 \\
\hline Iron, $\%$ & 1.9 & 1.9 & 2.4 & 1.6 & 2.0 \\
\hline Lead, mg/kg & 17 & 22 & 15 & 19 & 18 \\
\hline Lithium, mg/kg & 23 & 22 & 27 & 19 & 25 \\
\hline Manganese, $\mathrm{mg} / \mathrm{kg}$ & 420 & 500 & 600 & 510 & 520 \\
\hline Molybdenum, mg/kg & $<1$ & $<1$ & 1 & $<1$ & 1 \\
\hline Nickel, mg/kg & 16 & 17 & 20 & 14 & 16 \\
\hline Selenium, $\mathrm{mg} / \mathrm{kg}$ & .4 & 1.0 & .4 & .6 & .5 \\
\hline Silver, $\mathrm{mg} / \mathrm{kg}$ & $<.5$ & $<.5$ & $<.5$ & $<.5$ & $<.5$ \\
\hline Strontium, mg/kg & 120 & 140 & 120 & 140 & 130 \\
\hline Sulfur, $\%$ & .06 & .09 & .05 & .06 & .07 \\
\hline Thallium, mg/kg & $<50$ & $<50$ & $<50$ & $<50$ & $<50$ \\
\hline Tin, $\mathrm{mg} / \mathrm{kg}$ & 2 & 1 & $<1$ & -- & 2 \\
\hline Titanium, $\%$ & .39 & .33 & .41 & .35 & .44 \\
\hline Uranium, mg/kg & $<50$ & $<50$ & $<50$ & $<50$ & $<50$ \\
\hline Vanadium, mg/kg & 70 & 61 & 83 & 58 & 72 \\
\hline Zinc, $\mathrm{mg} / \mathrm{kg}$ & 55 & 80 & 67 & 79 & 50 \\
\hline \multicolumn{6}{|c|}{ Radionuclide } \\
\hline Cesium-137, pCi/g & .15 & .35 & .11 & .31 & .14 \\
\hline
\end{tabular}


Table A11. Percentage of clay and original constituent concentrations and cesium-137 activity for grassland-soil samples collected at individual sites in the Mission Lake subbasin, northeast Kansas, May 2005.

[mg/kg, milligrams per kilogram; \%, percent; pCi/g, picocuries per gram; <, less than; --, not determined]

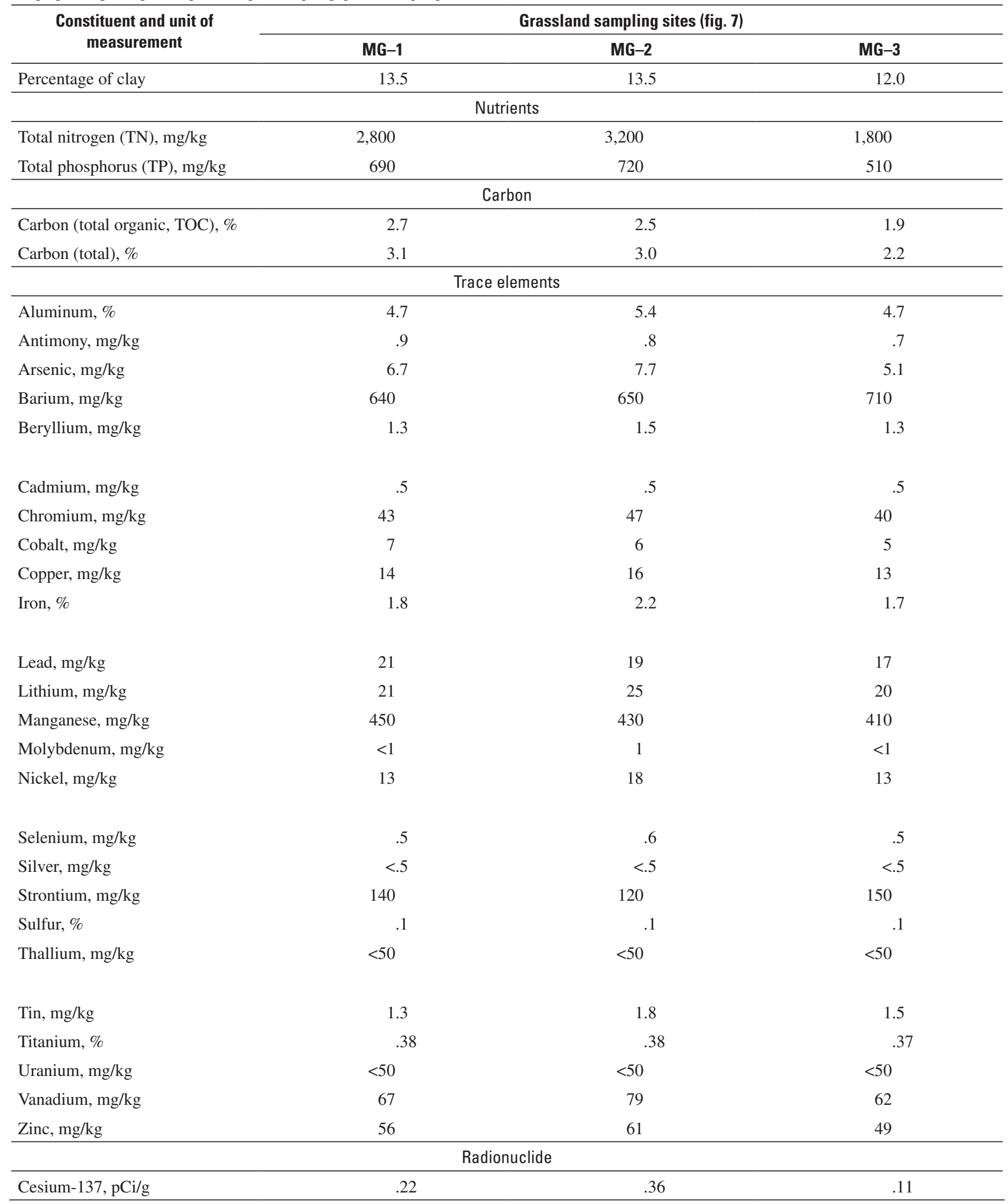


Table A12. Ratios of total organic carbon to total nitrogen, total organic carbon to total phosphorus, and total nitrogen to total phosphorus for channel-bank, cropland-soil, grassland-soil, surface-soil, and reservoir bottom-sediment samples collected in the Perry Lake and Lake Wabaunsee Basins, northeast Kansas, March-May 2005.

[TOC, total organic carbon; TN, total nitrogen; TP, total phosphorus; --, not available]

\begin{tabular}{|c|c|c|c|c|c|c|c|}
\hline \multirow{2}{*}{$\begin{array}{c}\text { Location } \\
\text { (figs. } 2 \text { and } 3 \text { ) }\end{array}$} & \multicolumn{4}{|c|}{ Source materials } & \multicolumn{3}{|c|}{ Reservoir bottom sediment } \\
\hline & $\begin{array}{c}\text { Channel } \\
\text { banks }{ }^{1}\end{array}$ & $\begin{array}{l}\text { Cropland } \\
\text { soils }^{1}\end{array}$ & $\begin{array}{c}\text { Grassland } \\
\text { soils }^{1}\end{array}$ & $\begin{array}{c}\text { Surface } \\
\text { soils }^{2}\end{array}$ & $\begin{array}{c}\text { Downstream } \\
\text { site }\end{array}$ & $\begin{array}{c}\text { Middle } \\
\text { site }\end{array}$ & $\begin{array}{l}\text { Upstream } \\
\text { site }\end{array}$ \\
\hline Atchison County Lake subbasin & 15.0 & 10.0 & 11.3 & 10.6 & 10.0 & -- & 10.0 \\
\hline Banner Creek Reservoir subbasin & 10.0 & 8.8 & 7.7 & 7.6 & 8.7 & -- & 9.5 \\
\hline Mission Lake subbasin & 12.9 & 10.9 & 9.2 & 10.4 & 9.2 & -- & 8.9 \\
\hline Walnut Creek subbasin & 14.0 & 10.7 & 10.4 & 10.5 & -- & -- & -- \\
\hline Delaware River & 7.5 & -- & -- & -- & -- & -- & -- \\
\hline \multicolumn{8}{|c|}{ TOC:TP ratio ${ }^{3}$} \\
\hline Atchison County Lake subbasin & 16.2 & 31.8 & 32.9 & 32.7 & 26.0 & -- & 26.3 \\
\hline Banner Creek Reservoir subbasin & 11.8 & 20.8 & 27.0 & 25.7 & 23.3 & -- & 24.7 \\
\hline Gregg Creek subbasin & 30.8 & 25.9 & 45.9 & 32.1 & -- & -- & -- \\
\hline Mission Lake subbasin & 20.5 & 39.3 & 37.5 & 38.7 & 21.8 & -- & 23.9 \\
\hline Walnut Creek subbasin & 18.9 & 26.7 & 46.8 & 34.4 & -- & -- & -- \\
\hline Delaware River & 5.9 & -- & -- & -- & -- & -- & -- \\
\hline Gregg Creek subbasin & 2.82 & 2.96 & 4.26 & 3.39 & -- & -- & -- \\
\hline Mission Lake subbasin & 1.59 & 3.61 & 4.06 & 3.71 & 2.36 & -- & 2.69 \\
\hline Walnut Creek subbasin & 1.35 & 2.50 & 4.52 & 3.28 & -- & -- & -- \\
\hline Delaware River & .78 & -- & -- & -- & -- & -- & -- \\
\hline Perry Lake & -- & -- & -- & -- & 1.94 & 1.82 & 1.73 \\
\hline Lake Wabaunsee Basin & .77 & -- & 5.27 & -- & 2.99 & -- & 3.39 \\
\hline
\end{tabular}


Table A13. Clay-normalized total nitrogen, total phosphorus, and total organic carbon concentrations and clay-normalized cesium-137 activity for channel-bank, cropland-soil, grassland-soil, surface-soil, and reservoir bottom-sediment samples collected in the Perry Lake and Lake Wabaunsee Basins, northeast Kansas, March-May 2005.

[mg/kg, milligrams per kilogram; \%, percent; pCi/g, picocuries per gram; --, not available; <, less than]

\begin{tabular}{|c|c|c|c|c|c|c|c|}
\hline \multirow{2}{*}{$\begin{array}{c}\text { Location } \\
\text { (figs. } 2 \text { and } 3 \text { ) }\end{array}$} & \multicolumn{4}{|c|}{ Source materials ${ }^{1}$} & \multicolumn{3}{|c|}{ Reservoir bottom sediment ${ }^{1}$} \\
\hline & $\begin{array}{l}\text { Channel } \\
\text { banks }^{2}\end{array}$ & $\begin{array}{c}\text { Cropland } \\
\text { soils }^{2}\end{array}$ & $\begin{array}{c}\text { Grassland } \\
\text { soils }^{2}\end{array}$ & $\begin{array}{c}\text { Surface } \\
\text { soils }^{3}\end{array}$ & $\begin{array}{c}\text { Downstream } \\
\text { site }\end{array}$ & Middle site & $\begin{array}{l}\text { Upstream } \\
\text { site }\end{array}$ \\
\hline \multicolumn{8}{|c|}{ Total nitrogen (TN), mg/kg } \\
\hline Atchison County Lake subbasin & 1,850 & 7,040 & 12,500 & 8,160 & 4,960 & -- & 6,230 \\
\hline Banner Creek Reservoir subbasin & 2,140 & 7,300 & 11,800 & 11,300 & 5,910 & -- & 6,370 \\
\hline Gregg Creek subbasin & 6,670 & 9,700 & 18,800 & 13,400 & -- & -- & -- \\
\hline Mission Lake subbasin & 4,050 & 15,200 & 20,000 & 16,300 & 5,490 & -- & 4,840 \\
\hline Walnut Creek subbasin & 3,270 & 9,550 & 30,800 & 15,000 & -- & -- & -- \\
\hline Delaware River & 2,630 & -- & -- & -- & -- & -- & -- \\
\hline Perry Lake & -- & -- & -- & -- & 3,170 & 3,350 & 4,490 \\
\hline Lake Wabaunsee Basin & 906 & -- & 11,100 & -- & 4,990 & -- & 5,930 \\
\hline \multicolumn{8}{|c|}{ Total phosphorus (TP), mg/kg } \\
\hline Atchison County Lake subbasin & 1,710 & 2,210 & 4,290 & 2,650 & 1,910 & -- & 2,370 \\
\hline Banner Creek Reservoir subbasin & 1,810 & 3,090 & 3,360 & 3,330 & 2,210 & -- & 2,450 \\
\hline Gregg Creek subbasin & 2,360 & 3,750 & 4,420 & 3,940 & -- & -- & -- \\
\hline Mission Lake subbasin & 2,550 & 4,210 & 4,920 & 4,400 & 2,320 & -- & 1,800 \\
\hline Walnut Creek subbasin & 2,420 & 3,820 & 6,810 & 4,590 & -- & -- & -- \\
\hline Delaware River & 3,360 & -- & -- & -- & -- & -- & -- \\
\hline Perry Lake & -- & -- & -- & -- & 1,640 & 1,840 & 2,600 \\
\hline Lake Wabaunsee Basin & 1,180 & -- & 2,100 & -- & 1,670 & -- & 1,750 \\
\hline \multicolumn{8}{|c|}{ Total organic carbon (TOC), \% } \\
\hline Atchison County Lake subbasin & 2.8 & 7.0 & 14.1 & 8.7 & 5.0 & -- & 6.2 \\
\hline Banner Creek Reservoir subbasin & 2.1 & 6.4 & 9.1 & 8.6 & 5.1 & -- & 6.1 \\
\hline Gregg Creek subbasin & 7.3 & 9.7 & 20.3 & 12.7 & -- & -- & -- \\
\hline Mission Lake subbasin & 5.2 & 16.6 & 18.5 & 17.0 & 5.1 & -- & 4.3 \\
\hline Walnut Creek subbasin & 4.6 & 10.2 & 31.9 & 15.8 & -- & -- & -- \\
\hline Delaware River & 2.0 & -- & -- & -- & -- & -- & -- \\
\hline Perry Lake & -- & -- & -- & -- & 2.8 & 3.0 & 4.8 \\
\hline Lake Wabaunsee Basin & 1.2 & -- & 11.5 & -- & 4.4 & -- & 5.6 \\
\hline
\end{tabular}


Table A13. Clay-normalized total nitrogen, total phosphorus, and total organic carbon concentrations and clay-normalized cesium-137 activity for channel-bank, cropland-soil, grassland-soil, surface-soil, and reservoir bottom-sediment samples collected in the Perry Lake and Lake Wabaunsee Basins, northeast Kansas, March-May 2005.-Continued

[mg/kg, milligrams per kilogram; \%, percent; pCi/g, picocuries per gram; --, not available; <, less than]

\begin{tabular}{|c|c|c|c|c|c|c|c|}
\hline \multirow{2}{*}{$\begin{array}{c}\text { Location } \\
\text { (figs. } 2 \text { and } 3 \text { ) }\end{array}$} & \multicolumn{4}{|c|}{ Source materials ${ }^{1}$} & \multicolumn{3}{|c|}{ Reservoir bottom sediment ${ }^{1}$} \\
\hline & $\begin{array}{c}\text { Channel } \\
\text { banks }^{2}\end{array}$ & $\begin{array}{l}\text { Cropland } \\
\text { soils }^{2}\end{array}$ & $\begin{array}{l}\text { Grassland } \\
\text { soils }^{2}\end{array}$ & $\begin{array}{l}\text { Surface } \\
\text { soils }^{3}\end{array}$ & $\begin{array}{c}\text { Downstream } \\
\text { site }\end{array}$ & Middle site & $\begin{array}{l}\text { Upstream } \\
\text { site }\end{array}$ \\
\hline \multicolumn{8}{|c|}{ Cesium-137, pCi/g } \\
\hline Atchison County Lake subbasin & 0.23 & 0.65 & 0.98 & 0.71 & 0.50 & -- & 0.62 \\
\hline Banner Creek Reservoir subbasin & .25 & .56 & 1.41 & 1.26 & .23 & -- & .35 \\
\hline Gregg Creek subbasin & .36 & .56 & 3.12 & 1.27 & -- & -- & -- \\
\hline Mission Lake subbasin & .13 & 1.45 & 1.77 & 1.56 & .46 & -- & .35 \\
\hline Walnut Creek subbasin & 0 & .76 & 3.30 & 1.43 & -- & -- & -- \\
\hline Delaware River & 0 & -- & -- & -- & -- & -- & -- \\
\hline Perry Lake & -- & -- & -- & -- & .09 & .28 & .19 \\
\hline Lake Wabaunsee Basin & .03 & -- & 1.45 & -- & .61 & -- & .59 \\
\hline
\end{tabular}

${ }^{1}$ Constituent concentration or activity normalized by dividing by the percentage of clay. Clay content for the individual samples is provided in tables A1-A7, A9-A11, and A14.

${ }^{2}$ Composite of three to five sites. See table 2.

${ }^{3}$ Surface-soil constituent concentration or activity computed as the weighted average of the cropland and grassland constituent concentrations or activities for each subbasin using land use as the weighting factor. Land-use information for the subbasins is provided in table 1. 
Table A14. Percentage of clay and original and clay-normalized constituent concentrations and cesium-137 activity for channel-bank samples collected from the Delaware River (fig. 2), northeast Kansas, April and May 2005.

[mg/kg, milligrams per kilogram; \%, percent; pCi/g, picocuries per gram; <, less than; --, not determined]

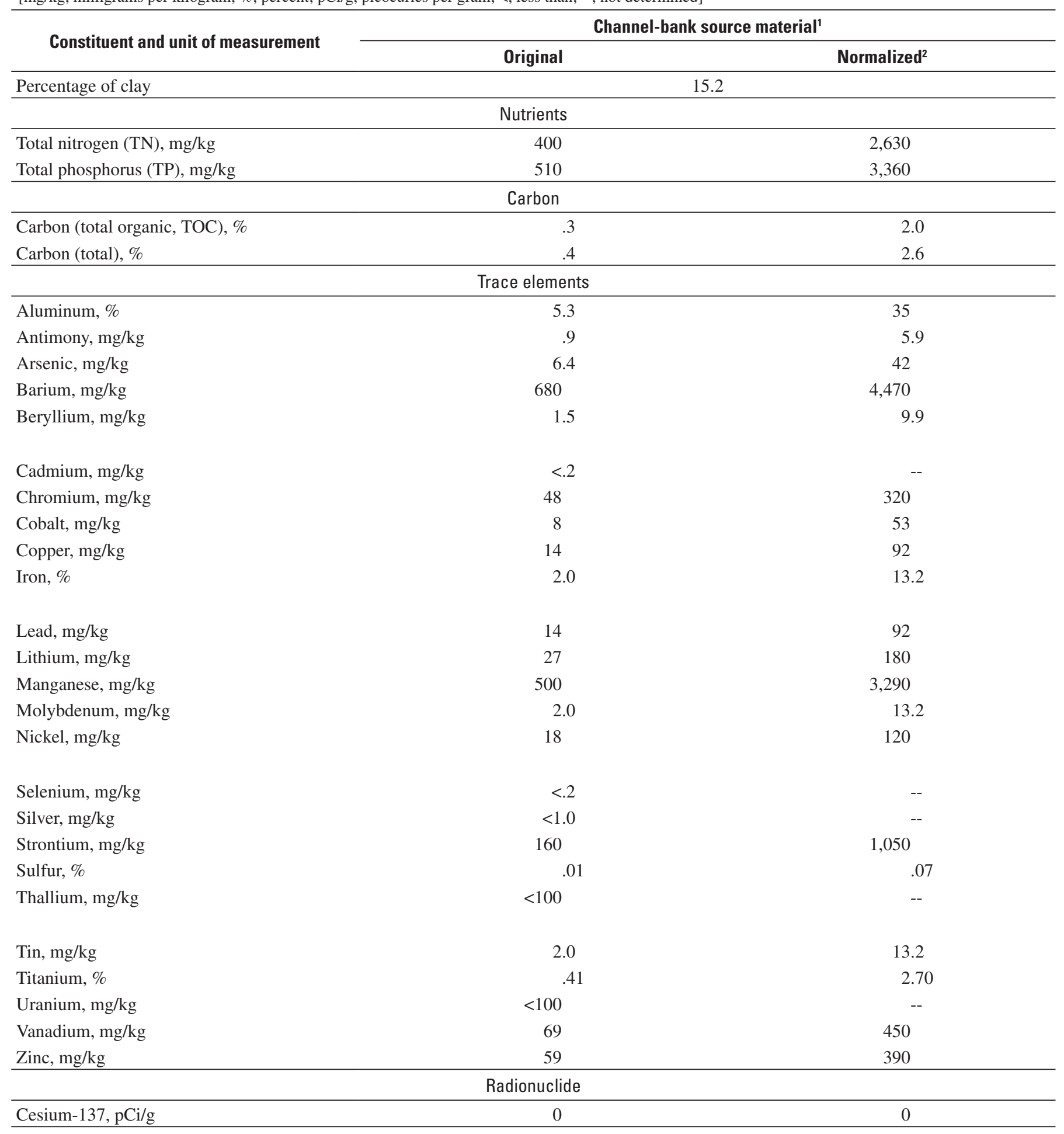

${ }^{1}$ Composite of three sites.

${ }^{2}$ Normalization achieved by dividing the original constituent concentration or cesium-137 activity by the percentage of clay. 
Table A15. Latitude and longitude coordinates for sampling sites in the Perry Lake and Lake Wabaunsee Basins, northeast Kansas.

[B, channel bank; C, cropland soil; G, grassland soil; R, reservoir bottom $]$

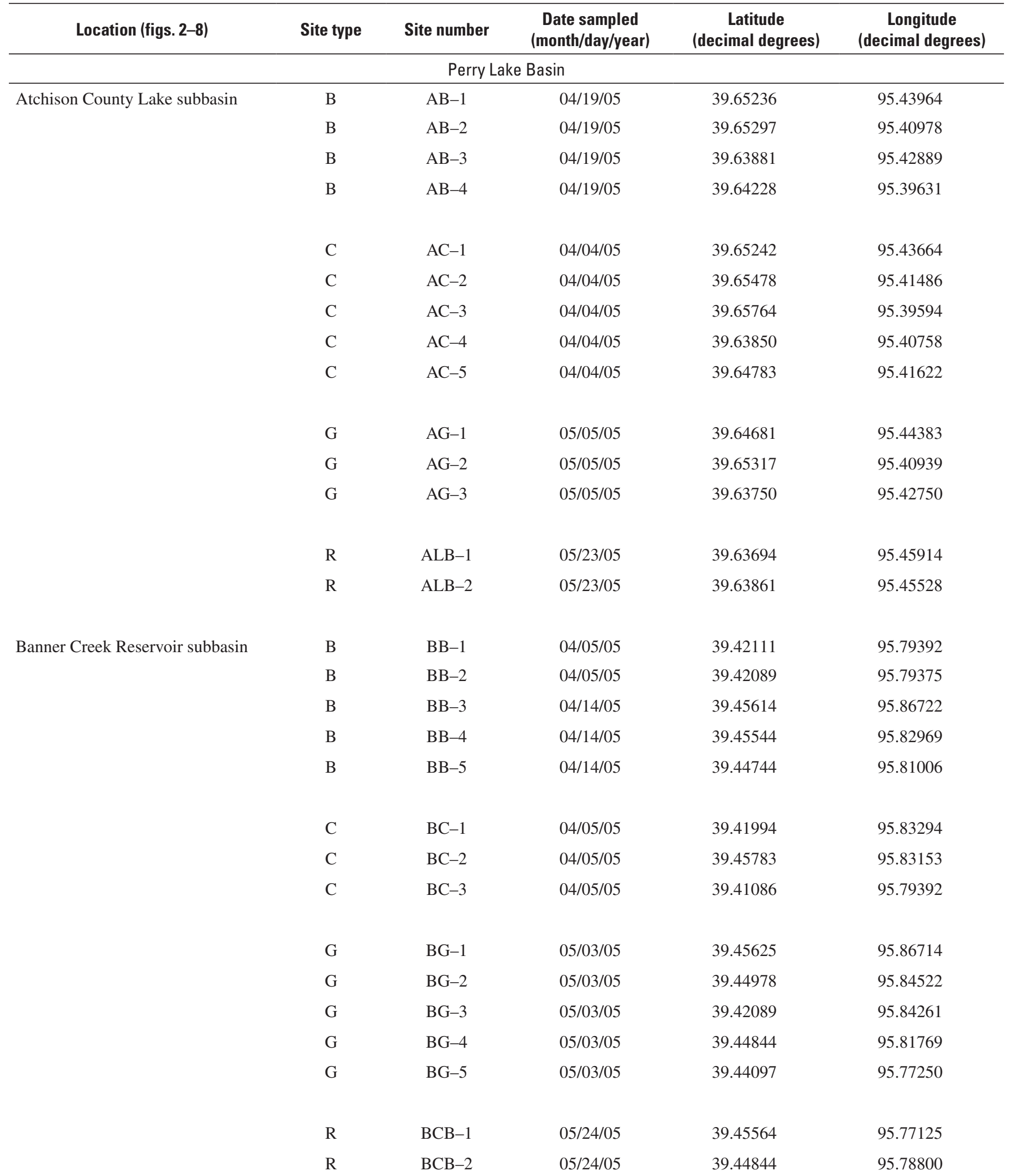


52 Estimation of Sediment Sources Using Selected Chemical Tracers in the Perry Lake and Lake Wabaunsee Basins

Table A15. Latitude and longitude coordinates for sampling sites in the Perry Lake and Lake Wabaunsee Basins, northeast Kansas. - Continued [B, channel bank; C, cropland soil; G, grassland soil; R, reservoir bottom]

\begin{tabular}{|c|c|c|c|c|c|}
\hline Location (figs. 2-8) & Site type & Site number & $\begin{array}{c}\text { Date sampled } \\
\text { (month/day/year) }\end{array}$ & $\begin{array}{c}\text { Latitude } \\
\text { (decimal degrees) }\end{array}$ & $\begin{array}{c}\text { Longitude } \\
\text { (decimal degrees) }\end{array}$ \\
\hline \multicolumn{6}{|c|}{ Perry Lake Basin-Continued } \\
\hline \multirow{8}{*}{ Gregg Creek subbasin } & $\mathrm{B}$ & GB-2 & 03/29/05 & 39.86203 & 95.86358 \\
\hline & B & GB-3 & 03/29/05 & 39.85053 & 95.86344 \\
\hline & $\mathrm{B}$ & GB-5 & 03/29/05 & 39.83586 & 95.84492 \\
\hline & $\mathrm{C}$ & $\mathrm{GC}-1$ & 03/29/05 & 39.87642 & 95.86386 \\
\hline & $\mathrm{C}$ & $\mathrm{GC}-2$ & 03/29/05 & 39.87089 & 95.85578 \\
\hline & $\mathrm{G}$ & GG-1 & $04 / 20 / 05$ & 39.86194 & 95.86444 \\
\hline & $\mathrm{G}$ & GG-2 & $04 / 20 / 05$ & 39.83458 & 95.88039 \\
\hline & $\mathrm{G}$ & GG-3 & $04 / 20 / 05$ & 39.82450 & 95.86744 \\
\hline \multirow[t]{11}{*}{ Mission Lake subbasin } & $\mathrm{B}$ & MB-1 & $03 / 31 / 05$ & 39.69600 & 95.53697 \\
\hline & $\mathrm{B}$ & MB-2 & 03/31/05 & 39.70928 & 95.53506 \\
\hline & $\mathrm{B}$ & $\mathrm{MB}-3$ & 03/31/05 & 39.71061 & 95.52083 \\
\hline & $\mathrm{C}$ & $\mathrm{MC}-3$ & 03/31/05 & 39.70258 & 95.50831 \\
\hline & $\mathrm{C}$ & $\mathrm{MC}-4$ & 03/31/05 & 39.69647 & 95.51969 \\
\hline & $\mathrm{C}$ & $\mathrm{MC}-5$ & 04/04/05 & 39.69006 & 95.52686 \\
\hline & G & MG-1 & 05/05/05 & 39.71094 & 95.53458 \\
\hline & G & MG-2 & 05/05/05 & 39.70556 & 95.51611 \\
\hline & G & MG-3 & 05/05/05 & 39.68831 & 95.50842 \\
\hline & $\mathrm{R}$ & MLB-1 & $05 / 23 / 05$ & 39.67469 & 95.51478 \\
\hline & $\mathrm{R}$ & MLB-2 & 05/23/05 & 39.68261 & 95.51919 \\
\hline \multirow[t]{2}{*}{ Walnut Creek subbasin } & $\mathrm{B}$ & WB-1 & 04/19/05 & 39.41589 & 95.36575 \\
\hline & $\mathrm{B}$ & WB-2 & 04/19/05 & 39.39147 & 95.36058 \\
\hline
\end{tabular}


Table A15. Latitude and longitude coordinates for sampling sites in the Perry Lake and Lake Wabaunsee Basins, northeast Kansas.—Continued

[B, channel bank; C, cropland soil; G, grassland soil; R, reservoir bottom]

\begin{tabular}{|c|c|c|c|c|c|}
\hline Location (figs. 2-8) & Site type & Site number & $\begin{array}{c}\text { Date sampled } \\
\text { (month/day/year) }\end{array}$ & $\begin{array}{c}\text { Latitude } \\
\text { (decimal degrees) }\end{array}$ & $\begin{array}{c}\text { Longitude } \\
\text { (decimal degrees) }\end{array}$ \\
\hline \multicolumn{6}{|c|}{ Perry Lake Basin-Continued } \\
\hline \multirow{10}{*}{ Walnut Creek subbasin-Continued } & $\mathrm{B}$ & WB-4 & $04 / 28 / 05$ & 39.39189 & 95.38531 \\
\hline & $\mathrm{B}$ & WB-5 & $04 / 28 / 05$ & 39.40561 & 95.37769 \\
\hline & $\mathrm{C}$ & WC-1 & $04 / 04 / 05$ & 39.39619 & 95.34833 \\
\hline & $\mathrm{C}$ & WC-2 & $04 / 04 / 05$ & 39.37669 & 95.35167 \\
\hline & $\mathrm{C}$ & WC-3 & $04 / 04 / 05$ & 39.42006 & 95.36761 \\
\hline & $\mathrm{C}$ & $\mathrm{WC}-4$ & 04/04/05 & 39.40539 & 95.38597 \\
\hline & $\mathrm{G}$ & WG-2 & 05/05/05 & 39.41600 & 95.36539 \\
\hline & G & WG-3 & $05 / 05 / 05$ & 39.37739 & 95.39497 \\
\hline & $\mathrm{G}$ & WG-4 & $05 / 05 / 05$ & 39.39039 & 95.33533 \\
\hline & $\mathrm{G}$ & WG-5 & $05 / 05 / 05$ & 39.36189 & 95.35514 \\
\hline \multirow[t]{3}{*}{ Delaware River } & $\mathrm{B}$ & DB-1 & $04 / 28 / 05$ & 39.66825 & 95.66003 \\
\hline & $\mathrm{B}$ & DB-2 & $05 / 03 / 05$ & 39.49417 & 95.53725 \\
\hline & $\mathrm{B}$ & DB-3 & 05/03/05 & 39.35050 & 95.45222 \\
\hline \multirow[t]{10}{*}{ Lake Wabaunsee Basin } & $\mathrm{B}$ & LB-1 & $05 / 20 / 05$ & 38.84983 & 96.18178 \\
\hline & $\mathrm{B}$ & LB-2 & $05 / 20 / 05$ & 38.84769 & 96.18661 \\
\hline & $\mathrm{B}$ & LB-3 & $05 / 20 / 05$ & 38.84983 & 96.19856 \\
\hline & $\mathrm{B}$ & LB-4 & $05 / 20 / 05$ & 38.86500 & 96.15631 \\
\hline & $\mathrm{G}$ & LG-1 & $05 / 20 / 05$ & 38.85089 & 96.18236 \\
\hline & G & LG-2 & $05 / 20 / 05$ & 38.84675 & 96.18658 \\
\hline & G & LG-3 & $05 / 20 / 05$ & 38.85033 & 96.20000 \\
\hline & G & LG-4 & $05 / 20 / 05$ & 38.86881 & 96.14114 \\
\hline & $\mathrm{R}$ & LWB-1 & $05 / 25 / 05$ & 38.86403 & 96.19703 \\
\hline & $\mathrm{R}$ & LWB-2 & $05 / 25 / 05$ & 38.85836 & 96.19219 \\
\hline
\end{tabular}


Prepared by Lawrence Publishing Service Center. Edited by Lanna Combs.

Graphics by Jeff Hartley and Mike Kemppainen.

Layout and design by Kristi Hartley.

For more information concerning the research described in this report, contact:

U.S. Geological Survey

4821 Quail Crest Place

Lawrence, KS 66049

(785) 842-9909

http://ks.water.usgs.gov 



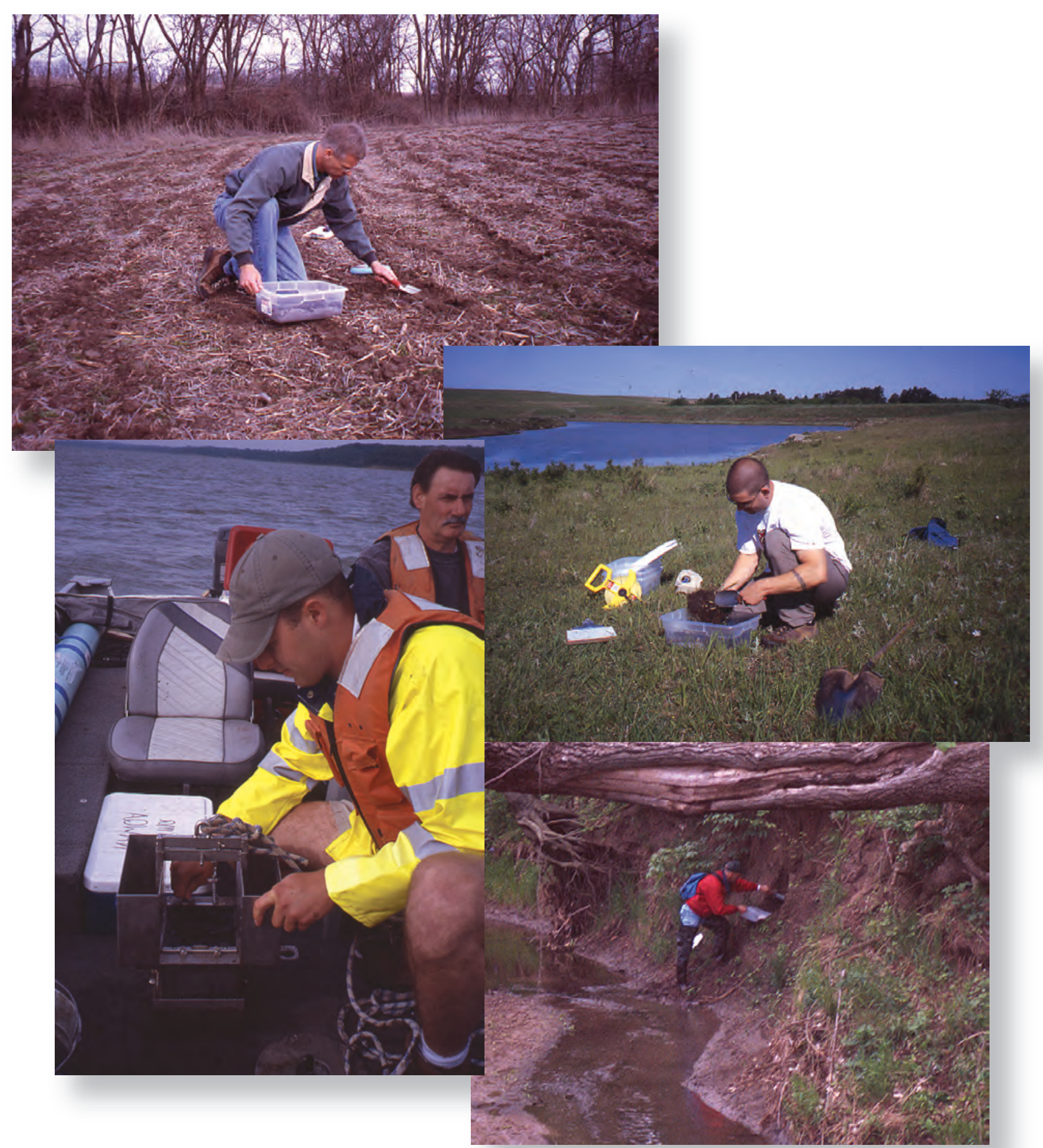

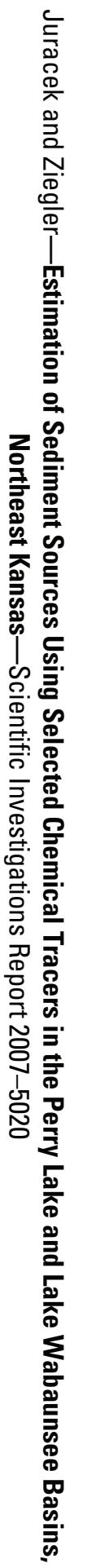

